THALES KRONENBERGER

\title{
SÍTIOS DE INTERAÇÃO ALTERNATIVOS EM RECEPTORES NUCLEARES E SUA VIABILIDADE COMO ALVOS TERAPÊUTICOS USANDO TRIAGEM COMPUTACIONAL E EXPERIMENTAL
}

\begin{abstract}
Dissertação apresentada ao Programa de Pós-Graduação em Biologia da Relação Patógeno-Hospedeiro do Instituto de Ciências Biomédicas da Universidade de São Paulo, para obtenção do título de Doutor em Ciências.
\end{abstract}


THALES KRONENBERGER

TARGETING ALTERNATIVE LIGAND-BINDING SITES IN NUCLEAR RECEPTORS USING COMPUTATIONAL AND

EXPERIMENTAL SCREENING

Ph. D. Thesis presented to the Post-graduation program Biology of Host-Pathogen Interactions at the Institute of Biomedical Sciences of the University of São Paulo, in order to obtain the degree of Doctor in Sciences

São Paulo

2017 
THALES KRONENBERGER

\section{SÍTIOS DE INTERAÇÃO ALTERNATIVOS EM RECEPTORES NUCLEARES E SUA VIABILIDADE COMO ALVOS TERAPÊUTICOS USANDO TRIAGEM COMPUTACIONAL E EXPERIMENTAL}

Dissertação apresentada ao Programa de PósGraduação em Biologia da Relação PatógenoHospedeiro do Instituto de Ciências Biomédicas da Universidade de São Paulo, para obtenção do título de Doutor em Ciências.

Área de concentração: Biologia da Relação Patógeno-Hospedeiro

Orientador: Carsten Wrenger Co-Orientador: Björn Windshügel Co-Orientador: Oliver Burk

Versão original

São Paulo

2017 
THALES KRONENBERGER

TARGETING ALTERNATIVE LIGAND-BINDING SITES IN NUCLEAR RECEPTORS USING COMPUTATIONAL AND EXPERIMENTAL SCREENING

Ph. D. Thesis presented to the Post-graduation program Biology of Host-Pathogen Interactions at the Institute of Biomedical Sciences of the University of São Paulo, in order to obtain the degree of Doctor in Sciences

Area of : Biology of Host-Pathogen Interactions

Supervisor: Carsten Wrenger

Co- Supervisor: Björn Windshügel

Co- Supervisor: Oliver Burk

Original Version

São Paulo

2017 


\section{CATALOGAÇÃO NA PUBLICAÇÃO (CIP) Serviço de Biblioteca e informação Biomédica do Instituto de Ciências Biomédicas da Universidade de São Paulo}

Ficha Catalográfica elaborada pelo(a) autor(a)

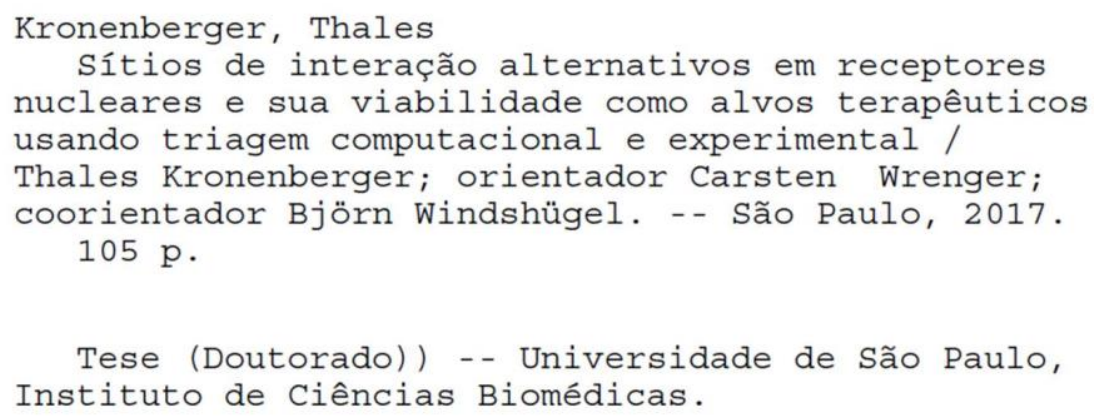

1. Receptor Constitutivo de Androstano. 2. Receptor X de Pregnano. 3. Antagonista. 4. Agonista inverso. 5. Triagem de fármacos. I. Wrenger, Carsten, orientador. II. Windshügel, Björn, coorientador. III. Título. 

Candidato(a): Thales Kronenberger

Titulo da Dissertação/Tese: Sítios de Interação Alternativos em receptores nucleares e sua viabilidade como alvos terapêuticos usando triagem computacional e experimental

Orientador: Carsten Wrenger

A Comissão Julgadora dos trabalhos de Defesa da Dissertação de Mestrado/Tese de Doutorado, em sessão publica realizada a ............................. considerou o(a) candidato(a):

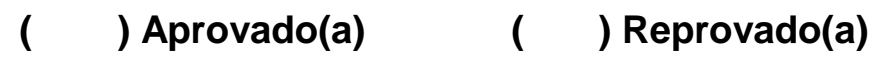

Examinador(a):

Examinador(a):

Examinador(a):

Presidente:
Assinatura:

Nome:

Instituição:

Assinatura:

Nome:

Instituição:

Assinatura:

Nome:

Instituição:

Assinatura:

Nome:

Instituição: 


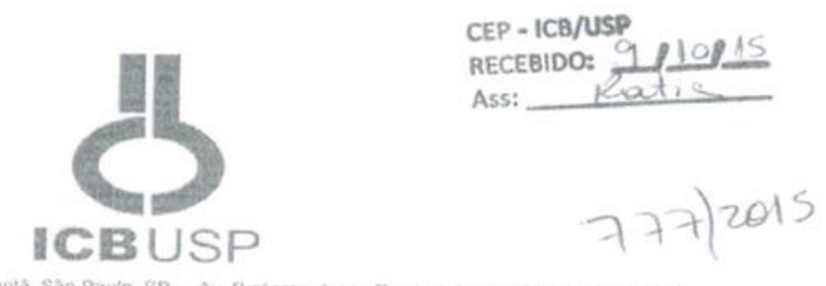

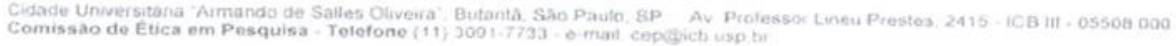

IImo. Srs.

São Paulo, 09 de outobro de 2015

Prof. Dr. Wothan Tavares de Lima

Coordenador da Comissão de Ética no Uso de Animais - CEUA

Prof. Dr. Paolo Marinho de Andrade Zanotto

Coordenador da Comissão de Ética em Pesquisa com Seres Humanos - CEPSH

Prezados Professores,

Ref: Solicitação de Certificado de Isencão

Vimos por meio deste solicitar Certificado de isenção das Comissōes de Ética no Uso de Animias (CEUA-ICB/USP) e Comissão de Ética em Pesquisa Com Seres Humanos (CEPSH-ICB/USP), visto que o projeto de pesquisa intitulado "Targeting Alternative LigandBinding Sites in Nuclear Receptors Using Computational and Experimental Screening" sob a responsabilidade do aluno Thales Kronenberger e orientação do Prof. Dr. Carsten Wrenger do Departamento de Parasitologia, nảo fará coleta nem uso de amostras biológicas e/ou células primárias provenientes de seres humanos bem como não utilizará seres humanos como veículo ou hospedeiro para coleta e manutenção de insetos ou organismos invertebrados.

Declaro ainda que os animais utilizados no referido projeto não estão sob a égide da Lei Federal 11,794 de 8 de outubro de 2008.

Por fim, informo que o projeto $(\mathbf{X X )}$ não utilizará células imortalizadas/( ) utilizará células imortalizadas (caso afirmativo, preencha os dados abaixo).
Origem:
( )
( )
( ) - / ( ).

(A) animal

(H) humana

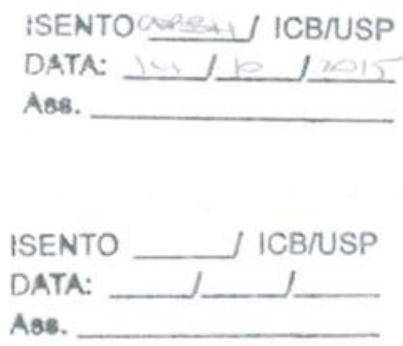

Orientador: Carsten Wrenger Atenciosamente,

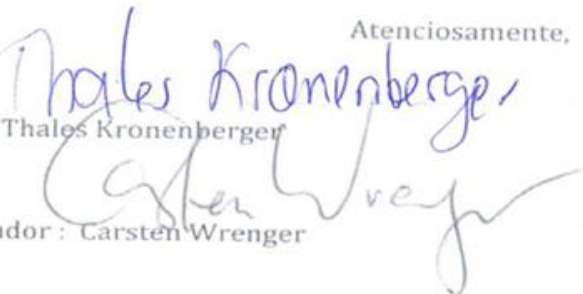

DATA

A8s.

Obs: Encaminhando o detalhamento do procedimento experimental que será utilizado. 
This work was supported by the São Paulo state funding agency FAPESP (Grants 2014/03644-9 and 2014/27313-1), CNPq-DAAD Science Without Borders program and by the Robert Bosch Foundation, Stuttgart, Germany. 
Eu dedico este trabalho à minha família, especialmente minha mae e madrinha, que sempre me apoiaram. 


\section{Acknowledgments}

Initially, I would like to thanks my supervisor C. Wrenger for receiving in the lab initially as a master student, but patiently helping me develop into the researcher I become today. In this line, I am grateful for all the assistance from the group of Unit for Drug Discovery during my time spent in Sao Paulo.

I am deeply thankful for the entire assistance and support provided by the Fraunhofer ScreeningPort Team in Hamburg, without it there would no possibility to this project to be conducted as the existed in the concept. Particularly I am thankful to Y. Heering and $O$ Keminer by the personal time spent teaching me the necessary cell culture techniques and assisting the experimental procedures, to $M$. Wolf introducing me to the HTS facilities and its peculiarities, to E. Sassetti and A. Gilardi for the scientific input and useful comments and discussions. In a higher sphere, I would like to thanks, B. Windshügel for the entire scientific support and orientation and C. Claussen for receiving me within his installations, I am thankful for both also for the career advises, which ultimately paved my path.

I am thankful for Dr O. Burk for receiving me within his lab, for the massive scientific input in the format of both discussion and technical instructions during the entire PhD time. I appreciate the expert technical assistance of both J. Jeske and K. AbuaziRincones. At last, but not least, the non-profit foundation Human Tissue and Cell Research (Regensburg, Germany), which holds a human tissue on trust, making it broadly available for research on an ethical and legal basis, which kindly provided liver tissue for the preparation of human primary hepatocytes. Primary human hepatocytes were kindly prepared by M. Demmel (Hepacult GmbH, München, Germany). 
"Drug-discovery is like finding a hay in the needle stack" PhD student after few failures 


\section{LIST OF ABBREVIATIONS}

$\mu l$ - microlitre

$\mu \mathrm{M}$ - micromolar

ABCB1 - ATP-binding cassette subfamily B member 1

ADME - absorption, distribution, metabolism and excretion

AKR1B10 - aldo-keto reductase family 1 member B10

CAR - constitutive androstane receptor

CYP - cytochrome P450

DDI - drug-drug interactions

DBD - DNA-binding domain

$E_{50}$ - half maximal effective concentration

EPHX1 - epoxide hydrolase 1

Eu - Europium

FASN - fatty acid synthase

FC - fold change

$\mathrm{FI}$ - fold induction

FRET - fluorescence resonance energy transfer

HTS - high-throughput screening

$\mathrm{IC}_{50}$ - inhibitory concentration

LBD - ligand-binding domain

LBP - ligand-binding pocket

MDR-1 - Multi-Drug Resistance Gene

$\mathrm{mM}$ - millimolar

NCOR - nuclear receptor co-repressor

$\mathrm{nm}$ - nanometre

NR - nuclear receptor

NRID - nuclear receptor interaction domain

PPAR - peroxisome proliferator-activated receptor

$\mathrm{PXR}$ - pregnane $\mathrm{X}$ receptor

RPLPO - ribosomal protein lateral stalk subunit P0

$R L U$ - relative luminescence units

SD - standard deviation

SEM - standard error of the mean 
SMRT - nuclear receptor corepressors

SRC-1 - steroid receptor coactivator-1

TR-FRET - time resolved fluorescence resonance energy transfer

UGT1A3 - UDP glucuronosyltransferase family 1 member A3

WT - wild type 


\section{LIST OF FIGURES}

Figure 1 - Schematic illustration of a nuclear receptor........................................22

Figure 2 - Cell based assays for nuclear receptor studies ......................................

Figure 3 - Identification of novel PXR antagonists ............................................51

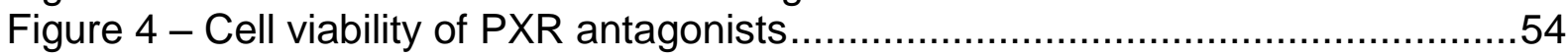

Figure 5 - Specificity of novel PXR antagonists............................................... 55

Figure 6 - PXR antagonists interfere with co-factor interaction and differentially

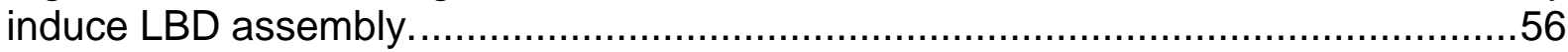

Figure 7 - Pimecrolimus and pazopanib, but not nelfinavir, inhibit LBP-filled PXR

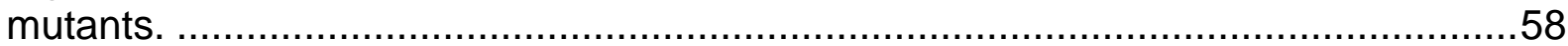

Figure 8 - Pimecrolimus and nelfinavir bind directly to PXR .............................59

Figure 9 - PXR antagonists reveal different LBD-binding. ..................................60

Figure 10 - PXR antagonist fluorescence emission upon specific excitation. ............60

Figure 11 - Suggested binding Modes of PXR antagonists. .................................61

Figure 12 - Novel PXR antagonists differentially affect the induction of PXRregulated genes by rifampicin in primary human hepatocytes.

Figure 13 - Screening of a chemical library of 784 compounds for CAR1 inhibition. 69

Figure 14 - CAR1 inverse agonist hit confirmation and selectivity towards CAR2. ...71

Figure 15 - Cell viability of CAR inverse agonists ............................................... 72

Figure 16 - miconazole, sulconazole and paclitaxel effectively activate the reporter activity of PXR, but not gefitinib or pazopanib. ..................................................73

Figure 17 - Binding of CAR inverse agonists to PXR ligand binding pocket. ............74

Figure 18 - Receptor Assembly and Coactivator Recruitment. ..............................74

Figure 19 - Inverse agonists block the SRC1 recruitment by CAR1 .....................76

Figure 20 - Predicted binding modes of CAR inverse agonists on the AF-2 region. .77 


\section{LIST OF TABLES}

Table 1 - Summary of antagonist candidates with $\geq 50 \%$ inhibition in the primary

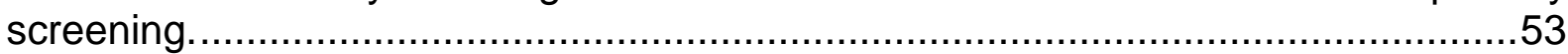

Table 2 - Docking scores of top-ranked poses of newly identified PXR inhibitors ....63 Table 3 - Amino acid residues of the PXR LBP and AF-2 site interacting with the docked ligands. 64 Table 4 - Primary Screening Hits and Hit Confirmation Results. .............................68 Table 5 - Docking scores of the top-ranked poses for the newly identified CAR

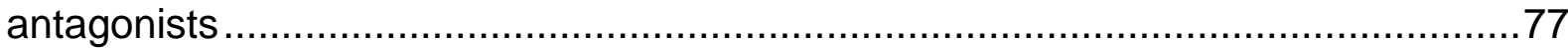
Table 6 - List of amino acid residues of CAR1 - AF2 region interacting with docked

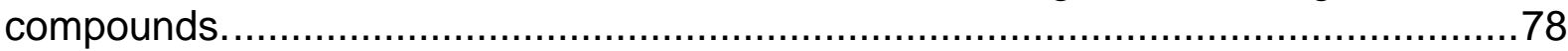




\section{LIST OF CONTENTS}

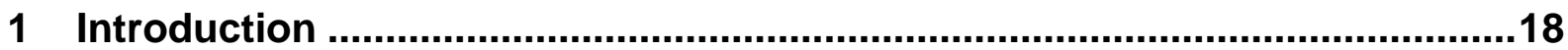

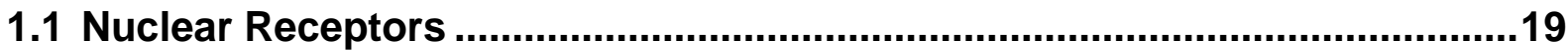

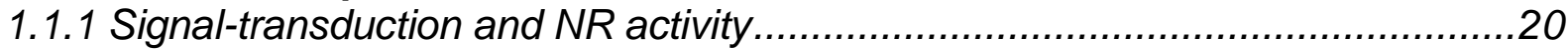

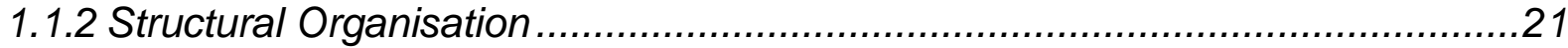

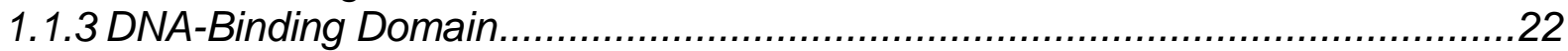

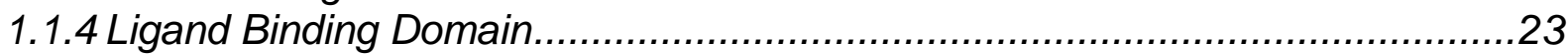

1.2 Drugs Modulating Nuclear Receptors............................................................24

1.3 Xenobiotic metabolism and the role of xenosensors...................................28

1.3.1 Constitutive Androstane Receptor (CAR) .............................................28

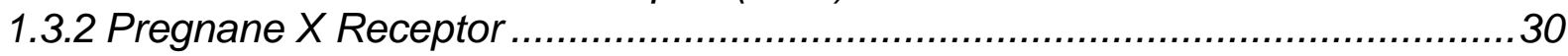

1.4 Methods to assess ligand binding and/or activation of nuclear receptors ..31

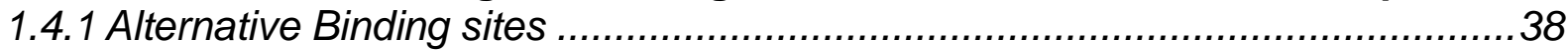

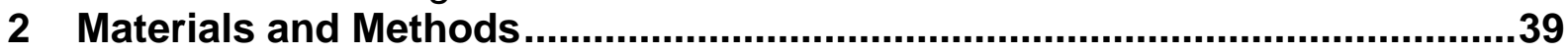

2.1 Chemicals and biological reagents ..........................................................

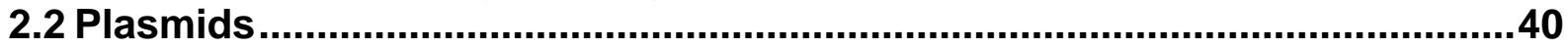

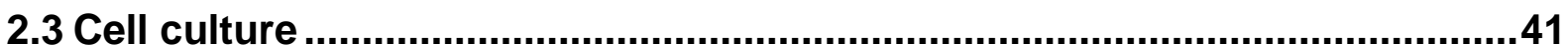

2.4 High-throughput screening and dose-response studies .............................42

2.4.1 Transactivation assay for PXR antagonist screening...................................42

2.4.2 Transactivation assay for CAR inverse screening ...................................... 42

2.4.3 Activity evaluation with dual luciferase system and data analyses ..................43

2.5 NR specificity, mammalian two-hybrid and mutant PXR assays....................44

2.6 Cell viability assays ........................................................................................44

2.7 Mammalian two-hybrid assay and CAR complementary assays....................44

2.8 Human primary hepatocytes ..................................................................45

2.9 RNA isolation and reverse transcription quantitative real-time PCR analysis 45

2.10 Limited proteolytic digestion ...........................................................................46

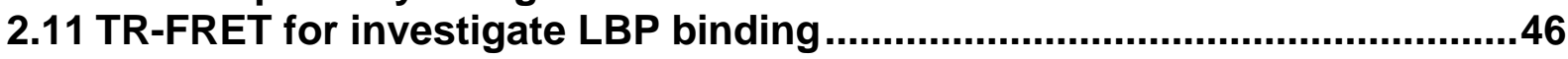

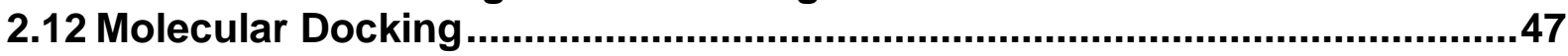

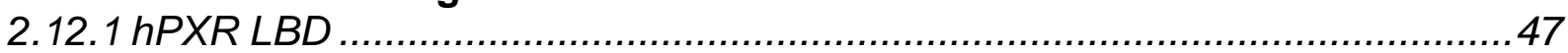

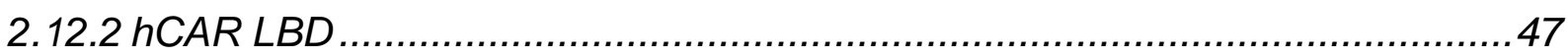

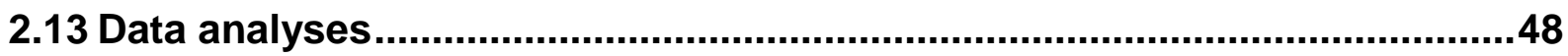

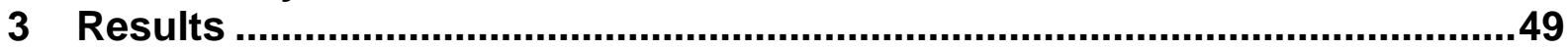

3.1 Identification of novel PXR antagonists ................................................50

3.1.1 Nuclear receptor selectivity of novel PXR antagonists..................................53

3.1.2 Novel antagonists disrupt co-regulator protein interactions with PXR while differentially inducing PXR-LBD assembly ....................................................5 3.1.3 Pimecrolimus and pazopanib inhibit the constitutive activity of LBP-filled PXR mutants 56

3.1.4 Novel PXR antagonists bind directly to the PXR LBD..................................57

3.1.5 Molecular docking of novel antagonists into LBP and AF2 region of PXR........59

3.1.6 Novel antagonists differentially impair induction of PXR-regulated genes by rifampicin in primary human hepatocytes ..........................................................64

3.2 Identification of CAR Inverse Agonists ........................................................66

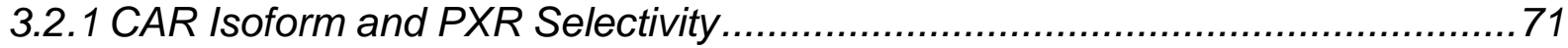


3.2.2 Ligand-Binding Domain Assembly and Co-activator Recruitment .................. 73

3.2.3 Inverse agonist interaction with AF-2 site ................................................. 75

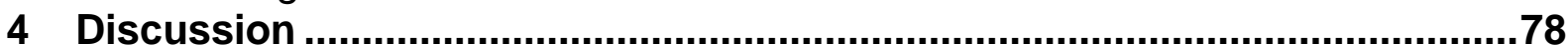

4.1 Identification of novel PXR antagonists ...................................................... 79

4.2 Identification of novel CAR inverse agonists................................................ 82

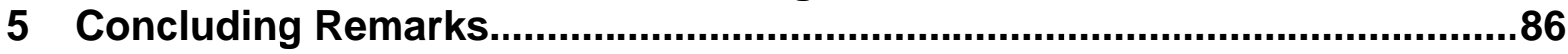

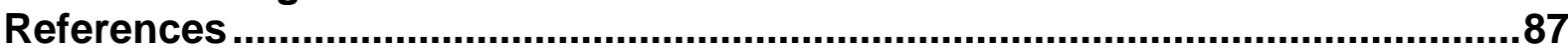




\section{RESUMO}

Kronenberger T. Sítios de interação alternativos em receptores nucleares e sua viabilidade como alvos terapêuticos usando triagem computacional e experimental. [tese (Doutorado em Biologia da Relação Patógeno-Hospedeiro)]. São Paulo: Instituto de Ciências Biomédicas, Universidade de São Paulo; 2017.

Receptores nucleares controlam a transcrição em células eucarióticas quando ativados por ligantes e, além do sítio de interação com ligantes, há outros sítios alternativos em sua superfície que podem ser alvo de compostos capazes de interferir com as interações proteína-proteína desativando o RN. A ativação do Receptor X de Pregnano (RXP) e do Receptor Constitutivo de Androstano (RCA) resulta na indução do metabolismo e efluxo de fármacos. Portanto, RXP/RCA sao responsáveis por causar reações adversas ou falhar terapias. Uma abordagem combinando a triagem experimental à nível cellular, em uma biblioteca de fármacos, e validação com ensaios in vitro e in silico, conseguimos identificar três novos antagonistas de RXP e cinco novos contra RCA, cada um com um perfil único de interação.

Palavras-chave: Receptor Constitutivo de Androstano, Receptor X de Pregnano, High-throughput screening, Agonistas inversos, Antagonistas, Descoberta de fármacos 


\begin{abstract}
Kronenberger T. Targeting Alternative Ligand-Binding Sites in Nuclear Receptors Using Computational and Experimental Screening. [Ph. D. thesis (Host-Pathogen Relationship Biology)]. São Paulo: Instituto de Ciências Biomédicas, Universidade de São Paulo; 2017.
\end{abstract}

Nuclear receptors can control transcription in eukaryotic cells in a ligand-dependent manner and, besides the ligand-binding pocket there is evidence of the existence of alternative ligand-binding sites on the surface, which can be addressed by small organic molecules that disrupt specific protein-protein interactions and thereby may antagonise NR function. Activation of pregnane $X$ receptor (PXR) and constitutive androstane receptor (CAR) results in the induction of first-pass metabolism and drug efflux. Hereby PXR/CAR may cause adverse drug reactions or therapeutic failure of drugs. Therefore, PXR and/or CAR antagonists can minimise adverse effects or improve therapeutic efficiencies. Combination of cellular high-throughput screen identified CAR and PXR potent antagonists in a library of approved and investigational drugs. Further validated by cellular and in vitro assays, as well as molecular docking, suggesting additional or exclusive binding outside the classical ligand binding pocket. In conclusion, we here have identified three approved drugs as novel potent PXR antagonists and five potential CAR inverse agonists with differential receptor interaction profiles.

Keywords: Constitutive Andronstane Receptor, Pregnane X Receptor, Antagonist, High-throughput screening, Inverse Agonist, Drug-Discovery 
1 INTRODUCTION 


\section{$1.1 \quad$ Nuclear Receptors}

Biological systems are often characterised by a great complexity accomplished by a multitude of diverse interactions between its integral parts. This applies not only to the macroscopic level, but is also valid for the smallest biological building blocks, the cells, whether of protozoan or metazoan nature. Intracellular communication is required for retention of the organisation and the physiological properties of the cell as well as its adaption capability to varying conditions. In multi-cellular organisms the intercellular interactions play also a significant role exemplified by diverse endocrine signals. Referring to signal transduction, intracellular communication processes often comprise successive biochemical reactions triggering changes in the gene expression profile, energy status or cell locomotion, respectively. Chemical signals comprise small molecules such as steroidal hormones as well as cyclic nucleotides and phosphoinositide derivatives.

During the last decades, nuclear receptors (NRs) have emerged as key elements in the intracellular signal transduction of metazoans [1]. By responding to a large variety of hormonal and metabolic signals, NRs act as ligand-activated transcription factors, thus playing a crucial role in the regulation of gene expression. Moreover, NRs are targeted by other signalling cascades and integrate diverse signal transduction pathways involving them in numerous physiological processes comprising development, differentiation, homoeostasis and reproduction [2]. Although the signal molecules such as steroid and thyroid hormones have been isolated in the early 20th century, the targets of those compounds remained unknown for several decades. In 1974, the correlation between hormone action and alterations in the gene expression status was reported [3]. Later studies revealed the classic model of the NR signalling pathway described in detail in the next section [4]. The first NRs were cloned in 1985 and represented the starting point of the modern NR research [5-7]. Additional NRs were subsequently identified suggesting the existence of a large NR superfamily, which evolved from one ancestral orphan receptor up to the current status, composed of altogether six sub-families (NR1-NR6) [8-10]. The numerous and often delusive denotations of NRs finally led to an unified nomenclature system that relies on the homology to other NRs in the most conserved regions [11]. The number of NR genes between species is quite diverse. As an example, $21 \mathrm{NR}$ genes have been revealed in Drosophila melanogaster, whereas in Caenorhabitis elegans more than 
270 genes have been identified [12]. In humans altogether 48 NRs have been discovered so far, but the number of functionally different NR proteins is by far larger due to alternative splicing processes [13].

\subsubsection{Signal-transduction and NR activity}

Gene transcription and protein translation processes are strictly regulated. Usually, transcription is prevented by the chromatin into which the DNA is assembled. Chromatin is the structural building block of a chromosome composed of nucleosomes [14]. Each nucleosome is composed of a core that is constituted by histone proteins around which the DNA is wrapped. Besides providing the lowest level of DNA compaction, nucleosomes are also important for gene regulation. Depending on the acetylation state of histone proteins, the chromatin adopts a more condensed or a more open form that prevents or allows the access of the basal transcription machinery, thus repressing or initiating protein biosynthesis. NRs regulate the gene expression by modulating the histone acetylation status of chromatin at their target gene, thus initiating or silencing the first step of the protein biosynthesis, the transcription process. NRs recognise and bind to specific binding sites in the promoter region of the gene referred to as response element (RE) [15]. Depending on the type of RE, NRs not only stimulate gene expression (positive RE), but also may have silencing effects via negative elements that are located in close vicinity of the transcription initiation site or even downstream of the TATA box [1618]. The canonical core recognition motif of REs consists of a central hexameric element having the consensus sequence 5'-AGGTCA-3' [19]. Number and configuration of the core motif, as well as the 5 '-flanking region, determines the specificity and affinity of the binding NR [20,21]. The length of the spacer region between the core motifs influences the NR specificity as well [22,23]. Usually, NRs bind as homo- (Type I) or heterodimers (Type II) to their respective REs whose core motifs can be configured as direct repeats (DR), everted repeats (ER) or palindromes. Steroid hormone receptors (e.g. ER, AR, GR) almost exclusively recognise REs organised as palindromes whereas non-steroidal receptors (e.g. VDR, PPAR, RXR) recognise response elements of different configurations [24]. Activation of gene expression requires co-activators and other protein factors to be recruited to 
the promoter-bound NR that serves as a nucleation site for a large multi-protein complex containing histone modifying and chromatin remodelling activities [25]. Usually, un-liganded NRs are complexed to co-repressors such as the silencing mediator of retinoid and thyroid receptors (SMRT) or the nuclear receptor corepressor (NCoR) [26,27], which are both recruiting histone deacetylases and chromatin and, remodelling proteins thus rendering the promoter transcriptionally silent [28]. Distinct groups of co-activators with different properties are necessary for NR-dependent transcription: Bridging co-activators act as connectors between NRs and proteins carrying histone modifying or chromatin remodelling activities [29]. These type of co-activators, formed by members of the steroid receptor co-activator (SRC) [30] family, bind to NRs via their nuclear receptor interaction domain (NRID), an amphipathic helix containing a conserved $L x x L L$ motif $(L$ is leucine whereas $x$ is any amino acid) [31,32]. Other types of co-activators are constituted by histonemodifying proteins (histone acetyltransferases, histone methyltransferases and histone kinases) and chromatin remodelling complexes both opening the promoter by unpacking the DNA from histones [28,33,34]. Furthermore, mediator complexes facilitate binding of RNA polymerase II to the promoter and thus help to establish the pre-initiation complex consisting of general transcription factors (e.g. TFIID) and the RNA polymerase II [35]. In contrast to NR activation, antagonist binding can stabilise the NR-co-repressor interactions or even prevent the NR from adopting an active conformation as shown for raloxifene or tamoxifen in the oestrogen receptor [36-38].

\subsubsection{Structural Organisation}

Nuclear receptors share a conserved structural and functional organisation (Figure 1). Altogether four distinct regions have been characterised which comprise the $\mathrm{N}$ terminal region $A / B$, a conserved $D N A$-binding domain ( $D B D$, region $C$ ), a linker region $D$ and a ligand-binding domain (region $E$ ). Some nuclear receptors also contain a C-terminal extension (region F) of yet unknown function. 
Figure 1 - Schematic illustration of a nuclear receptor.

\begin{tabular}{|c|c|c|c|c|}
\hline $\begin{array}{c}\mathrm{N} \text { - terminal } \\
\text { Domain }\end{array}$ & DBD & $\begin{array}{c}\text { Hinge } \\
\text { region }\end{array}$ & $\begin{array}{c}\text { Ligand Binding } \\
\text { Domain }\end{array}$ & $\begin{array}{c}\text { C-terminal } \\
\text { Domain }\end{array}$ \\
\hline$A / B$ & $\mathrm{C}$ & $\mathrm{D}$ & $\mathrm{E}$ & $\mathrm{F}$ \\
\hline
\end{tabular}

\section{LDB}

Protein-protein interaction

Transactivation (AF-2)

Ligand binding

Dimerisation

\section{NTD}

Post-traductional modifications

Protein-protein interactions

Transactivation (AF-1)

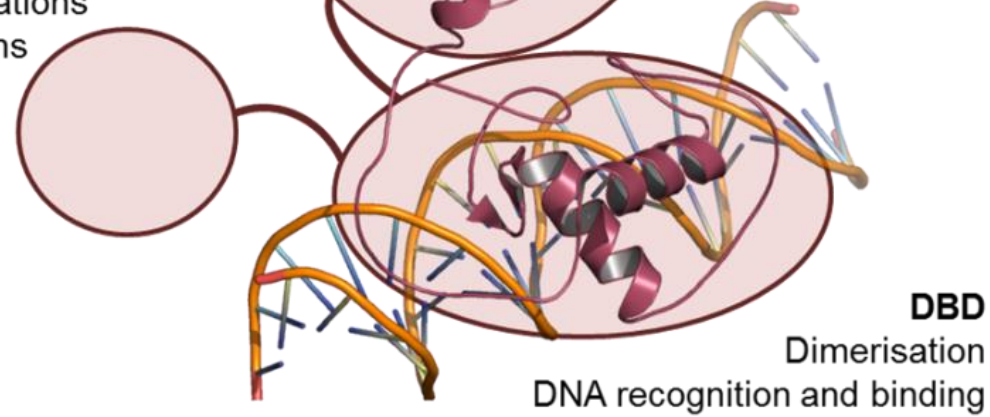

Top - Schematic 1D of a nuclear receptor. Bottom - 3D structural illustration of the DBD (bound to DNA) and LBD (bound to hormone) regions of the nuclear receptor. $N$-terminal domain (A/B), hinge region $(D)$, and $C$-terminal domain $(F)$ are given in red, purple, and orange dashed lines, respectively. X-ray crystal structure (PDB code 3DZY of the PPAR $\gamma$ (violet) and RXRa (orange) DBD and LBD (cartoon representation) bound to DNA (CPK representation). The structure was solved in complex with NR agonists rosiglitazone (PPAR $\gamma$ ) and 9-cis retinoic acid (RXR $\alpha)$ as well as coactivator peptides (blue ribbons).

\subsubsection{DNA-Binding Domain}

Nuclear receptors recognise their specific target gene via the DNA-binding domain (DBD). The DBD represents the most conserved domain in NRs that is composed of two zinc-finger motifs and a C-terminal extension (CTE) domain encoded by roughly 60-70 amino acids [39]. Each zinc atom is coordinated in a tetrahedral arrangement by four highly conserved cysteine residues [40]. The three-dimensional structure of the DBD has been revealed by NMR and X-ray studies (Figure 1) [41-43]. 
Recognition of the target DNA is achieved by the so-called P-box located in the first zinc-finger whereas the second one harbours the D-box which provides the dimerisation determinants [23]. DBD post-translational modifications have been reported to modulate the receptor activation, such as CAR (Thr38) and TR [44]. Unlike the core DBD sequence, the CTE is not conserved among NRs and may adopt diverse structural motifs with diverse functions comprising sequence recognition or receptor dimerisation, respectively

\subsubsection{Ligand Binding Domain}

The LBD is a multifunctional domain that, besides the ligand binding site, also carries the ligand-dependent transcription activation function 2 (AF-2) $[45,46]$ as well as a dimerisation motif for RXRa [47,48] and a nuclear localisation signal [49]. Additionally, the LBD harbours binding sites for heat shock and co-regulatory proteins [29,50]. Despite a considerable variability in sequence, the LBDs of all nuclear receptors possess a canonical structure in which 12 to $14 \alpha$-helices, together with a (2-5) stranded-sheet, which are arranged in an anti-parallel, three-layered helix sandwich (Figure 1) [51-53]. Located between the outer sandwich layers, the ligandbinding pocket (LBP) is mainly constituted by hydrophobic aminoacids [54]. The size of the LBP can diverge considerably among different NRs ranging from $100 \AA^{3}$ (ERR) up to $1300 \AA^{3}$ (PPAR) [55-57], with exceptions such as NURR1 with an uncommonly small ligand binding cavity [58].

Nuclear receptors are associated with many diseases and therefore represent promising drug targets. Androgen receptor (AR) and oestrogen receptor $\alpha(E R \alpha)$ are targeted for the treatment of various forms of cancer (AR: prostate cancer, ERa: breast cancer) while PPAR $\gamma$ plays a role in cancer and diabetes and, depending on the disease is addressed by agonists and antagonists. Hepatocyte nuclear factor $4 \alpha$ (HNF4 $\alpha$ ) is involved in maturity-onset diabetes of the young, type 1. Pregnane $X$ receptor (PXR) in turn is responsible for drug metabolism and is also involved in metabolic diseases. 


\subsection{Drugs Modulating Nuclear Receptors}

Besides other drug targets such as G protein-coupled receptors, ion channels, receptor tyrosine kinases and immunoglobulin-like receptors, nuclear receptors represent another major receptor target class. Of the 48 nuclear receptors in humans, about a third is already targeted by approved drugs. Most of these receptors belong to the subfamilies NR1 and NR3 and the main indication areas are cancer and hormone replacement. As of 2011, 76 approved drugs targeting 17 nuclear receptors were available [59].

A classical NR-drug is tamoxifen, the first approved agent for breast cancer prevention and treatment. The compound is a potent antagonist of the oestrogen receptor $(E R)$, belonging to the steroid hormone receptors. Being a prodrug, tamoxifen requires conversion by cytochromes CYP2D6 and CYP3A4 in the liver into the bioactive forms 4-hydroxytamoxifen and N-desmethyl-4-hydroxytamoxifen, respectively. The metabolites have improved affinity for the ER by the fold of up to 100 times [60]. The tamoxifen metabolites can be taken up to the breast tissue, acting then as competitive inhibitors of oestrogen hormones in the ligand pocket of the ER. Curiously, in other tissues such as the endometrial, tamoxifen acts as potent ER agonist [61]. ER three-dimensional structures, determined in co-crystallisation studies with both the drug and peptide of the protein partners, show that the ligand induces an inactive conformation of the receptor, by sterically displacing $\mathrm{H} 12$ from the active conformation [57].

Although significant anti-breast cancer effects of tamoxifen justify its application, the drug reveals several serious side effects. Tamoxifen can act either as an agonist or antagonist on different tissues, depending on the estradiol concentration and hence the menopausal status of the patient. The effects of the use of tamoxifen use during the pregnancy are also adverse, foremost resulting in foetus malformation [62].

Another selective oestrogen receptor modulator is the benzothiophene raloxifene. The compound is not a prodrug as tamoxifen. Also, its effect is different as raloxifene does not show any antitumor activity. Instead, the compound is used for prevention of osteoporosis and may reduce the incidence of breast cancer in postmenopausal women.

Both SERMs are T-shaped molecules. The core structure of both compounds is planar and binds in a similar orientation into the ligand-binding pocket as the natural 
ligand $17 \beta$-estradiol. The side chain protruding from the core structure is responsible for the sterical displacement of AF-2 from the active conformation, thereby preventing co-activator binding and eventually inactivating the receptor.

The ligand-binding pocket of several nuclear receptors has already been exploited for pharmaceutical purposes. Several approved drugs either activate or inhibit nuclear receptor function by competing with the natural ligand. The first drug targeting a nuclear receptor was cortisone that GR, using the purified cortisone from gland extracts, in order to reduce the inflammatory effect.

The cortisone synthesis opened the door for more potent glucocorticoid receptor agonist currently in use for therapy of inflammatory diseases, such as the dexamethasone and the prednisolone. The crystal structure of the GR with dexamethasone is an example of how the ligand binding can influence the LBD conformation since the AF-2 helix is present in an active position allowing the coactivator protein to interact [63]. On the other hand, GR structures with the antagonist (RU486) showed a dimethylaniline group preventing the AF-2 to assume the active position [64]. Those two studies together suggest that AF-2 helix, as well the region nearby, can be disposed to high flexibility leading to ligand-induced conformational changes.

This structural knowledge allowed the chemistry to synthesise compounds which are able to activate only a subset of the GR functions, modulating the expression of specific genes, thus retaining the anti-inflammatory effect, altogether reducing the side-effects on the bone metabolism and glucose control $[65,66]$.The entire steroid hormone ligand binding pocket linger common structures that allow them to bind natural hormones, for instance, $75 \%$ of their residues are hydrophobic accommodating the steroid hormone common scaffold. It is also known that the few conserved polar residues are responsible by orientating the hormone towards the proper fitting within the pocket between helices 3 and 5 [67]. Besides the GR and the ER mentioned before, other steroid receptors which have been exploited as drugtarget, are the androgen receptor $(A R)$. Unlike the other receptor mechanism, testosterone (or its reduced form 5-dihydrotestosterone) binds to the NR and induces the FxxLF motif of the N-terminal domain to interact with the AF-2 region [68]. 5dihydrotestosterone dissociates more slowly than testosterone from AR and thereby better stabilises the AR complex. 
AR is known to be involved in several diseases, among those the prostate cancer is worthy to be highlighted since the androgen can stimulate growth, survival and also inhibit apoptosis. One common therapy includes the androgen deprivation, however more recent approaches indicate the interference with androgen binding [69,70]. There are two major pathways targeted in prostate cancer: i) the inhibition of CYP17A1, an enzyme required for the androsterone biosynthesis by drugs such as abiraterone and ii) the direct interference with the androgen receptor by antagonists (e.g. galeterone and enzalutamide).

The enzalutamide (or MDV3100) is an androgen receptor antagonist, designed to bind to the ligand binding pocket and thereby preventing AR translocation to the nucleus [71]. Enzalutamide was able to prolong the life of cancer patients, who did not receive chemotherapy, with only a few registered side-effects [72].

Mutations in LBD render the competitive inhibitors, therefore, several groups have focused on the DBD. The use of virtual screening combined with the chemical improvement of compounds resulted in molecules able to inhibit enzalutamideresistant cells [73,74].

Another receptor targeted by FDA-approved drugs belong to the group of peroxisome proliferator-activated receptors (PPAR) [75]. Three PPAR subtypes have been identified: alpha, delta (also called beta) and gamma. All receptors have different roles in the regulation of the lipid and glucose metabolism. Drugs targeting PPARs are mainly used for the treatment of metabolic syndrome, in particular for lowering triglycerides and blood glucose level. Endogenous ligands of PPARs comprise free fatty acids and eicosanoids. Some compounds are specifically binding to PPAR subtypes such as prostaglandins for PPAR $\gamma$.

Fundamentally, the full agonist is able to interact with polar residues within the ligand binding pocket stabilizing the interaction with the $\mathrm{H} 12$, more exactly the Tyr473 within the AF2 helix, while the partial agonist does not have this polar interaction or interact on someplace else [76,77].

The ligand pocket of PPARs is normally large in order to accommodate different fatty acids, the PPAR pockets can be divided into three arms: one rich in polar residues and other two hydrophobic. The first one with polar residues includes the activation function 2 (AF-2 helix), able to bind to the thiazolidinedione group. The hydrogen bond network between the ligand and the amino-acid residues Tyr464, Tyr314 and 
Ser280 on PPARa and Tyr473, His449, His323 and Ser289 on the other two PPAR [78].

Compound selectivity for the different PPARs can be achieved by the exploitation of just a few residues by contacting of the compounds with the lateral residue of those mentioned amino-acids, as following: PPAR alpha has the major affinity towards saturated fatty acids; PPAR gamma and delta presents two histidine residues allowing the interaction with unsaturated fatty acids and PPAR delta has a couple of specific bulky residues Val334, Leu339 and lle364, important for the selectivity of the ligands [76,79].

Contrary to PPAR alpha and gamma, which has been widely exploited as drugtargets, the PPAR delta has no clinically relevant ligands. Besides several computational efforts towards selecting specific agonists [80-82], just one molecule has reached phase II clinical trial for the treatment of dyslipidaemic syndrome or diabetes [83]. In the last years, the focus has been drawn on PPAR delta which established the receptor as new drug-target. This has been corroborated by the function of PPAR-delta in the fatty acid metabolism, insulin resistance, reverse cholesterol transport and inflammation as discovered by knockout animals and specific drugs [84-86]

PPAR-delta was initially exploited by the use of nonsteroidal anti-inflammatory drugs [87]. The use of PPAR-delta antagonists and agonists have been tested on the cancer therapy, due to the high expression levels of this receptor in prostate cancer cells and colorectal tumours respectively [88].

At last, the development of non-specificity drugs leads to the appearance of pandrugs (either agonists or antagonists), which are able to bind and modulate common interfaces or pockets among the different PPARs. Due to the significant similarity among the different PPAR isoforms, several synthetic dual- or even pan-agonists were developed.

The use of pan-agonists was first proposed with the glitazars, aiming specifically the alpha and gamma subtypes, are looking forward have the benefit of the TZD, such as the reduction of the sugar levels without the cardiovascular risks [89]. The most wellknown fibrate with a pan-agonism profile of activity is the bezafibrate, proven to delay the diabetes progression in patients with sugar imbalance, increase of $\mathrm{HDL}$ cholesterol and a reduction of triglycerides [90]. 


\subsection{Xenobiotic metabolism and the role of xenosensors}

Most nuclear receptors are addressed because of their direct involvement in a disease. However, some members of the NR superfamily are interesting because of their involvement in drug metabolism. This process comprises three phases and involves modification processes (e.g. oxidation, reduction, hydroxylation), coupling reactions with hydrophilic compounds (e.g. glucuronic acid, glycine) and finally excretion of the metabolised molecules from the cell. Both pregnane $X$ receptor (PXR) and constitutive androstane receptor (CAR) are responsible for liganddependent induction of gene expression of proteins involved in phase I-III. Due to their ability to bind structurally and chemically diverse molecules, both receptors are also termed xenosensors.

It is suggested that CYP3A4 (Phase I enzyme) is responsible for the turnover of about $50 \%$ of the known drugs and, which correspond to the multi-resistance druggene (MDR1) spectrum of drugs [91]. Several authors have pointed out the leadership of CAR and PXR on the xenobiotic-sensing and detoxification (as reviewed by $[92,93])$ and regulation of either the cytochrome protein expression (highlighting the CYP3A4) or drug efflux mediated by the MDR1 [94].

\subsubsection{Constitutive Androstane Receptor (CAR)}

The constitutive androstane receptor (CAR, NR1l3) is a transcription factor from the nuclear receptor family, whose activity is regulated by endogenous and exogenous ligands [95]. Originally designated as orphan receptor due to the absence of any known endogenous ligand [96], a large set of compounds modulating CAR activity has been identified up to now [93]. CAR, together with the pregnane $X$ receptor (PXR, NR112), is involved in the metabolism of drugs and environmental chemicals by regulating the expression of important phase I and phase II metabolising enzymes as well as transporter proteins in a ligand-dependent manner $[97,98]$.

Another nuclear receptor involved regulation of drug metabolism is the constitutive androgen receptor (CAR). Known CAR ligands comprise 5-androstan-3-ol and 5androst-16-en-3-ol, but also pregnanedione [96,99]. The main expression of CAR is in the liver tissue and the intestine and reveals a pronounced basal activity in vitro 
$[100,101]$. Alternatively spliced variants of CAR have been also detected in adrenals, brain, spleen, prostate and testis that do not possess basal activity $[102,103]$.

In a similar way, as PXR does, CAR can dimerise with RXR and bind an ER6 (everted repeat of the response elements separated by 6 base pairs) in order to induce the expression of CYP3A4 genes [104]. Furthermore, when bound to phenobarbital, CAR can bind to DR4 motifs (i.e. two direct repeat response elements separated by $4 \mathrm{bp}$ ) within the enhancer PBREM (phenobarbital-responsive enhancer module) region of CYP2B genes [105]. Phenobarbital-like molecules such as pesticides or contaminants can act as CAR agonists, that would include chlorpromazine, phenytoin, dichlorodiphenyltrichloroethane (DDT), 1,4-bis[2-(3,5dichloropyridyloxy)]benzene (TCPOBOP) as well as polychlorinated biphenyls $[105,106]$.

Despite the interplay and overlap of ligands and target genes between CAR and PXR, specific CAR activation can contribute to drug resistance [107] and druginduced hepatotoxicity [108]. Additionally, it is well known that CAR can remain constitutively active even in the absence of ligands, depending on the cellular context [109]. Besides exogenous compounds, CAR activity can also be modulated by endogenous ligands, e.g. bile acids, dehydroepiandrosterone, androstenol and androstanol $[96,110]$. In this sense, CAR modulation participates in physiological conditions like obesity, diabetes and tumour development; as well it regulates pathways related to hepatic energy homeostasis [111], insulin signalling [112] and cell proliferation $[113,114]$.

Several different CAR splice variants have been reported, of which most are inactive. $[115,116]$. Only three of these have been described to be physiologically relevance: the canonical CAR1 (also termed CAR-SV1, 348 amino acids), CAR2 (CAR-SV3, containing a four amino acid insertion - VSPT - between helix 6 and 7) and CAR3 (CAR-SV2, containing a 5 amino acid insertion - APYLT - between helix 8 and 9) (Auerbach et al., 2003). Different isoforms possess distinct functional profiles. While both CAR1 and CAR2 are constitutively active, CAR3 does not possess a basal activity. The ligand spectrum of CAR1 and CAR2 is different, CAR1 is inducible by CITCO or pregnanedione and the basal activity can be reduced by androstanol or meclizine [118,119] whereas only a few agonists have been identified for CAR2 (e.g. the plasticizer di(2-ethylhexyl) phthalate), which are specific for that isoform [106]. In contrast to CAR1 and CAR2, CAR3 is not constitutively active and is more sensitive 
to ligand activation, such as CITCO [120]. The weak CAR1 antagonist clotrimazole was, surprisingly, an agonist for CAR3 and for the chimerical construct CAR1+A, which mutates the five amino acids insert for a single alanine [118,121]. On the other hand, strong CAR1 antagonist PK11195, a benzodiazepine receptor ligand, cannot further reduce the low CAR3 activity, regardless of CITCO treatment [122]. Recently, a qHTS assay has been used to identify CAR1+A non-specific modulators, resulting in the discovery of 115 CAR1+A activators and 154 antagonists [123].

Regardless of the new molecular study tools for CAR and the emergence value of this receptor as a drug target for several syndromes, so far only few inverse agonists are known: clotrimazole, meclizine, androstenol, PK11195 [96,118,122,124] and more recently CINPA1 and its analogues [125,126]. All compounds share at least some degree of cross-reactivity with other receptors, mainly PXR (Chai et al., 2016).

\subsubsection{Pregnane $X$ Receptor}

The pregnane $X$ receptor (PXR, NR112) together with the closely related constitutive androstane receptor (CAR, NR1I3) constitutes the xenobiotic sensing system in liver and intestine [127,128].

PXR is one of the most promiscuous nuclear receptors as it binds several clinically used drugs, among them calcium channel blockers, statins, antidiabetic drugs, HIV protease inhibitors and also artemisinin and its derivatives [127,129]. PXR X-ray crystal structures have unravelled the basis for the pronounced ligand promiscuity of the receptor. Due to a broken and kinked helix 6 as well as a long loop connecting $\mathrm{H} 1$ and $\mathrm{H} 3$ that is part of the ligand-binding pocket, the receptor can adapt to structurally and chemically diverse molecules. The molecular weight of compounds binding to PXR varies from 200 to more than 800 Da with rifampicin as largest known PXR agonist. PXR is constitutively expressed in the liver and intestine [130,131]. Upon activation, the receptor forms heterodimers with $R X R$. In particular activation of PXR may result in drug-drug interactions, adverse drug reactions or therapeutic failure of drugs $[132,133]$. PXR is activated by various small molecules, including clinically used drugs, environmental pollutants and natural products, but also endogenous compounds such as bile acids and pregnane metabolites [93,134]. 
In contrast to a large number of known PXR agonists, only few PXR antagonists have been reported so far. These comprise natural products such as ecteinascidin 743 [135], sulforaphane [136], coumestrol (Ekins et al., 2008; Wang et al., 2008), camptothecin [139], fucoxanthin [140] and sesamin [141], as well as synthetic compounds PCB197 [142], A-792611 [143], SPB00574 and SPB03255 [138] as well as the synthetic ketoconazole derivative FLB-12 [144,145]. In addition, several approved drugs, including ketoconazole, fluconazole, enilconazole, itraconazole [138,146], metformin [147] and leflunomide [138] have been identified to inhibit PXR.

Besides the conventional model of NR inhibition, which requires antagonist binding to the ligand-binding pocket (LBP), another mode of action is based on inhibitors addressing non-conventional sites on the ligand-binding domain (LBD) surface [148]. In addition, coumestrol has been shown to effectively inhibit constitutively active PXR mutants containing bulky LBP-filling amino acids (Wang et al., 2008), which suggests an additional binding site. FLB-12 has been suggested to exclusively bind outside of the LBP, as these compounds did not compete for binding to PXR with an established agonist in vitro but still inhibited the constitutive activity of the LBP-filled mutant [145]. In addition, molecular In silico pharmacophore modelling and molecular docking studies suggested binding of several known antagonists to the surface of the AF-2 region [138,149].

PXR antagonists could provide the opportunity to prevent or minimise drug-drug interactions or could be applied in order to reduce hepatic clearance, thus allowing a lower drug dosage [150]. By screening a compound library of approved and investigational drugs using a cell-based assay, followed by a set of confirmatory cellular assays, as well as in vitro binding and molecular docking investigations, we here have identified and characterised three drugs as novel PXR antagonists, which differentially interact with the receptor.

\subsection{Methods to assess ligand binding and/or activation of nuclear receptors}

In the last decades, a couple of molecular and cell biology methods have been applied to investigate nuclear receptor function and regulation [151]. In the following, a selection of most relevant methods is presented that are frequently used in NR research in academia and pharmaceutical industry. 
Standard molecular biology techniques like cDNA cloning have been used to identify the genes for orphan nuclear receptors. For the identification of hormone-response elements, electrophoretic mobility shift assays (EMSA) and chromatinimmunoprecipitation (ChIP) have been used as well as GST-pull down assays $[152,153]$. For the identification of natural ligands standard transactivation assays, GAL4-LBD fusion transactivation systems and also image based receptor translocation assays were used [154,155].

In order to demonstrate the direct and high-affinity binding of a ligand, a variety of compound binding assays have been developed. These can be divided into several classes. The fundamental ligand binding assay measures the competition for binding to the receptor with a known ligand [156]. For investigation of receptor conformational changes after ligand binding protease sensitivity and non-denaturating gel electrophoresis assay formats have been used. Another assay type that reports molecular consequences of ligand binding is called Co-activator-dependent receptor ligand assay (CARLA), which refers to a modified GST-pull-down assay [157]. More complex approaches include the protein nuclear magnetic resonance (NMR), which allows the analysis of conformational dynamics due to ligand binding in solution $[158,159]$. Recent studies associate an important role for protein dynamics in the mechanism of action of nuclear receptor ligands [160]. Detailed analyses of the macromolecular interaction of ligand binding including affinity and binding kinetics are performed by the surface plasmon resonance (SPR) technology [161]. This sensitive technology overcomes the limitations of old-fashioned filter binding assays, which were limited to low affinities or indirect non-equilibrium methods. In the standard SPA BIAcore approach small amounts of receptor protein are immobilised onto a solid phase, while the ligand is introduced to flow over the surface. Binding of the ligand leads to an increase in the refractive index. A linear relationship exists between the mass (concentration) of molecules bound the surface of the ship. SPR allow analysis of high-affinity protein-protein, protein-DNA interaction and the binding of small molecules [161].

Due to their relevance as therapeutic targets, the pharmaceutical industry prioritised the development of novel assay systems that allowed speeding up the throughput and the screening of large compound collections. Therefore in the last decade, a couple of academic laboratories, as well as big pharmaceuticals and biotech companies, spent much effort in the development of HTS compatible screening 
assays which assess ligand binding and/or activation of nuclear receptors (Reviewed by $[162,163])$. These efforts led to modified methodologies with higher throughput. Despite the fact that these assays have been designed for certain targets the principles could be expanded to any NR, making these assay formats accessible to screening purposes.

Most common screening systems for nuclear receptor activation are cell-based, transactivation assays". These assays rely on the potential of nuclear receptors to activate transcription in response to binding of a ligand $[164,165]$. This is achieved by transfection of a cell line with an expression vector for the receptor and a reporter vector that has the binding site for the receptor and also encodes for a protein that, when incubated with the appropriate substrate, yields a product that can be measured. The most common method for evaluation NR activation involves transient transfection of a receptor and a response element-reporter gene construct [97]. Binding of a ligand to the receptor leads to a binding of the activated receptor to the binding site on the reporter construct and an activation of transcription of the reporter gene. The main advantage of these cell-based assay is that they allow screening of large compound libraries in reproducible fashion [163].

By far, the most common method involves transient transfection and until now many cells lines have been described as possible recipients of these vectors, including $\mathrm{CHO}$, HuH7, MCF-7, HEK293, HepG2 and Caco-2 cells [98]. Using transient transfection systems a couple of investigators identified activators for human PXR, CAR and AhR (extensively reviewed by [93]). Testing known drugs within these systems were able to identify therapeutic agents which activate NR and cause DrugDrug Interactions (DDI) with high correlation [162,164,166]. Comparing those results with the ones from cell-based systems using primary cultures of hepatocytes, it was found that primary hepatocytes do not allow this identification due to the coregulation of the receptors and the crosstalk for target genes found among human CAR, PXR and AhR [167].

To reduce the variability associated with transient transfection stable cell lines have been generated that contain NR and the NR response element-reporter genes. In the past, a couple of cell lines have been generated to express hPXR and were used to predict the potential for DDI of new drugs in a rapid and simple approach [168]. The system allows multiplexing, which means that a single well can be used to determine a parameter for receptor activation, cell viability and induced enzyme activity [168- 
170]. Results from stable transfected cells can vary from standard transiently transfected assays and even primary cell-lines, which have to be taken into consideration [171,172].

An alternative or even complementary to transactivation assay system is the mammalian two-hybrid system. This assay system represents a powerful approach for detecting protein-protein interactions in cells, which has evolved from the original two-hybrid system into a method for identifying NR ligands. The system is based on the finding that co-activators and co-repressors are involved in the regulation of NR function. Recruitment of co-activators upon ligand binding is a critical step in NRmediated transcriptional activation. Following ligand binding, many NR undergoes a conformational change (e.g. PXR) and form a specific co-activator binding pocket, which permits the interaction with the receptor. In the mammalian two-hybrid approach, chimerical receptors containing the LBD of interest are fused to the DBD of the yeast transcription factor GAL4. The DBD binds to specific DNA response elements. The interaction between NR and its co-activator is detected using a reporter gene containing multiple copies of the GAL4 upstream activating system (UAS). Agonist binding to the LBD induces the formation of a complex which promotes the assembly of RNA polymerase II complex and subsequently enhances the transcription of the reporter gene [173].

Examples are mammalian two-hybrid assays consisting of the LBD of hCAR and coactivator SRC-1 fused to GAL4 (DBD). In that assay, the ligand binding enhances the interaction between LBD and SRC-1, which is detected by the reporter gene activity [120]. With similar assay setup, a couple of agonists and inverse agonist were identified for human CAR even if some results were contradictory [174]. It was speculated that the use truncated of chimerical receptors or resulted in subtle conformation changes and unspecific protein-protein interactions [98], leading to the conclusion that full-length receptors would be more sensitive and closely to the in vivo situation [163].

The study of PPAR inhibitors greatly benefited from the use of the double transfection system, using an expression plasmid of the NR and reporter gene construction. Despite the variety of different constructs, they all follow the same pattern; the NR construct is normally a plasmid that facilitates constitutive expression of the entire open reading frame of the NR in mammalian cells. The reporter construction resides commonly the open reading frame of luciferase which is cloned 
downstream of a promoter region fragment coupled to the hormone responsive element (HRE) or an enhancer [175]. Both plasmids can have resistance cassettes for stable transfection or be used on the basis of a transient expression system Figure 2B.

Figure 2 - Cell based assays for nuclear receptor studies
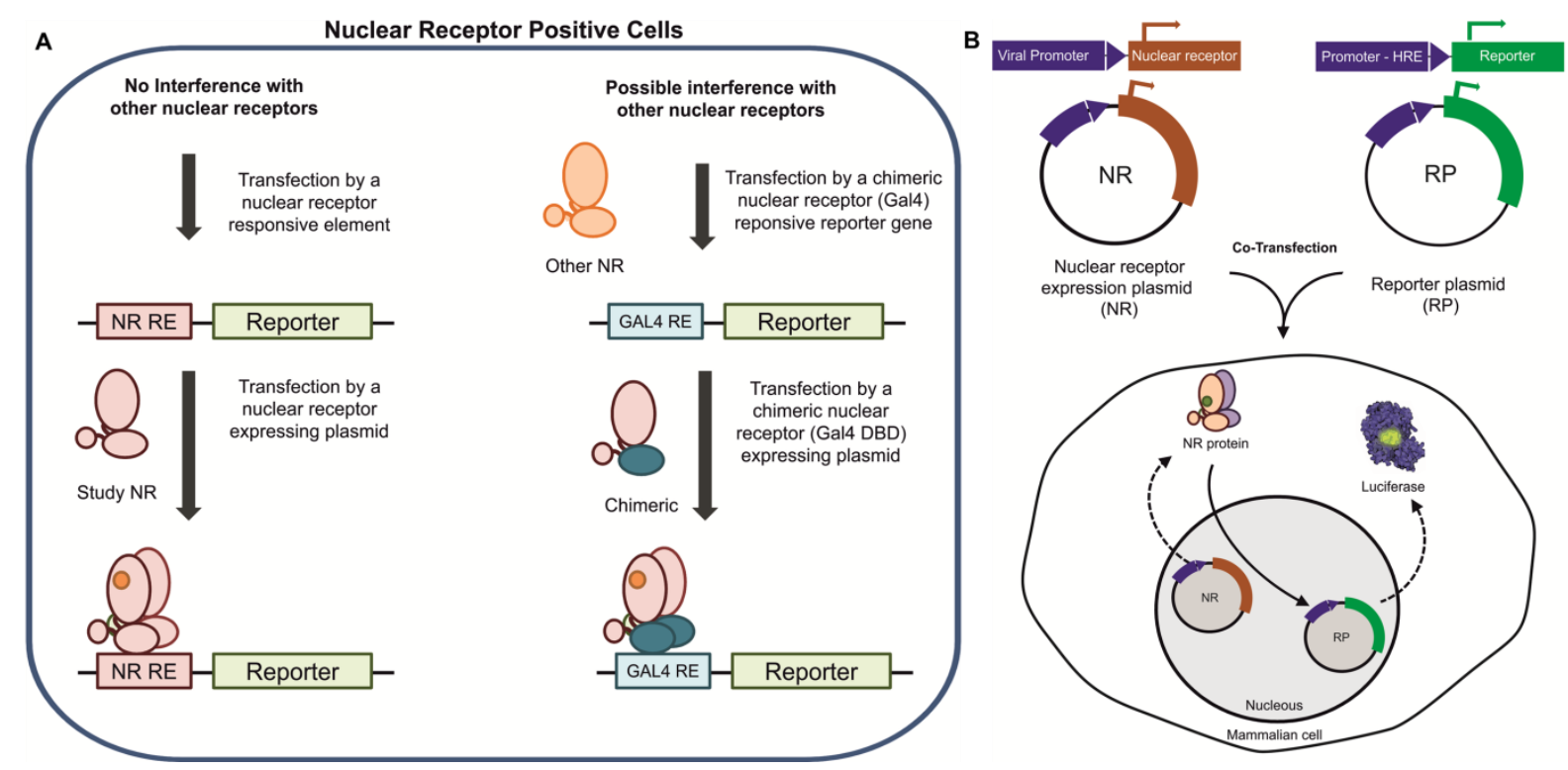

A) Transactivation assay rationale, the plasmid with constant expression B) Flow chart for decision between the different transactivation strategies, classical and one-hybrid assays, and the situations requiring each technique

Within this framework, the normal NR action follows: A mammal expression vector is used for the expression of the NR, which binds to the hormone, dimerises and interacts with the DNA sequence of the HRE at the reporter gene plasmid leading to the liberation of luciferase expression. In the presence of compounds with inhibitory/modulatory activity, the functionality of the NR can be verified by differences in the luciferase expression levels (Figure 2A). Another different methodology uses a similar general strategy however the mammalian expression vector resides the NR LBD fused to a GAL4 yeast DNA binding domain followed by the GAL4 promoter and the luciferase gene [176].

In principle, the two amended transactivation assays are applicable to highthroughput screening (HTS) and valuable for drug discovery. Quality criteria which characterise a certain assay for HTS are robustness, the sensitivity and 
reproducibility in identifying compounds that display significant $N R$ binding or activation. A very useful parameter which describes the criteria is the screening window coefficient (termed Z-factor), which is used to define the ratio of the separation band to signal dynamic range of a given assay [59]. This coefficient takes into account the signal dynamic range, the data variation associated with reference and control measurements. The Z-factor is a well-accepted parameter for evaluating HTS assay quality (from $0.5-1.0$ ) and a characteristic parameter of hit identification for a given assay under screening conditions [163,177].

With regard to high throughput ambitions, a couple of non-cell based assay formats were developed which passed these criteria (128-130). Rouleau \& Bossé (2006) described Assays based on AlphaScreenTM Technology, for oestrogen receptor alpha $(E R \alpha)$ and retinoic acid receptor gamma $(\operatorname{RAR} \gamma)$ as models to demonstrate important steps and principles to the development of AlphaScreen assays for NRs.

AlphaScreen $^{\mathrm{TM}}$ (Amplified Luminescent Proximity Assay) is a non-radioactive homogeneous proximity assay that relies on the transfer of energy between an acceptor and a donor bead brought into proximity via biological interaction. The donor beads are embedded with a photosensitizer (phthalocyanine), which converts oxygen to an excited state upon illumination. If a biomolecular interaction drags an acceptor bead into close proximity of a donor bead, the excited singlet oxygen will transfer its energy to the acceptor bead leading to the emission of light depending on the fluorophores in the acceptor beads (Tioxene, anthracene and rubrene, emission of light at $520-620 \mathrm{~nm}$ ). Each donor bead is capable of generating up to 60.000 singlet oxygen with a half-life of $0.3 \mathrm{sec}$, allowing measurements in a time-resolved mode and with substantial signal amplification. The technology can use to rapidly develop high-throughput screening (HTS) assays for NRs [59,178].

The principle of the assay involves two major steps: a) a ligand-activated biomolecular interaction between NR and its co-activator, followed by b) the detection of that interaction using AlphaScreen compatible reader technology. It is well established that following agonist binding, allosteric changes in the LBD of NR will allow the interaction between the AF-2 domain in the LBD and the NR box present in the coactivator structure. A consensus sequence present on all NR co-activators ( $L x x L L$ motif) is sufficient for the interaction with the agonist-bound receptor LBD. To establish assay configurations for certain NR, different components can be chosen depending on their cost and availability. Two general configurations are possible: i) 
Interaction between agonist, antagonist bound receptors and co-activator/corepressor; ii) Interaction between agonist bound to the ligand pocket domain and LxxLL motif-containing peptide. Depending on the detection reagents, the binding partners can be wild-type, truncated, or tagged with, for example, biotin, FITC, GST, Flag, c-Myc, HA or His 6 [179].

An assay based on the interaction between receptor and co-activator will generate a signal increase upon agonist binding while a signal decrease is following antagonist binding. The interaction with co-repressors could also be used to find ligands acting at different molecular events. A significant study by Rouleu \& Bossé (2006) showed, that AlphaScreen Assays for NR can be performed in 384 well plates with an intraplate variability generated $C V 10 \%$ and $Z$ values $>0.7$ [179].

Another well-validated assay type for studying NR-ligand interactions is based on the Lance $^{\mathrm{TM}}$ Technology [179]. In the Lance assay, a signal is generated when a donor molecule labelled with chelated Europium (Eu) gets into proximity of an acceptor molecule by its time labelled with allophycocyanin (APC). When a biological interaction brings the donor and the acceptor into close proximity, excitation of the Eu-chelate at $340 \mathrm{~nm}$ allows Fluorescence Resonance Energy Transfer (FRET) to the acceptor APC molecule resulting in fluorescence emission at $665 \mathrm{~nm}$. Long stakes shift and excited-state lifetimes of Europium complex of hundreds of microseconds make this technology perfect for Time-Resolved FRET (TR-FRET). In principle different binding partners can be used: i) Interactions between agonistbound receptor or receptor LBD and LxxLL motif-containing peptide and/or ii) interaction between an apo- or holo-receptor and the co-repressor interaction domain.

In the literature, a couple of examples are present describing the use of LANCE assays based on the interaction between the receptor and co-activator-derived peptide [180-182] (134-136). Most of these assays involve the interaction between biotinylated LxxLL peptides derived from a co-activator sequence and tagged receptor LBD. The complex formation is detected using Eu-labelled antibody and APC-labelled streptavidin. When both binding partners are biotinylated, the Lance assay can be performed using commercially available Eu-streptavidin and streptavidin-APC [183]. A great advantage of applying the LANCE technology is the long signal stability, which can reach more than $48 \mathrm{~h}$, allowing batch processing in HTS. 
Besides experimental approaches, also computational methods are extensively applied in order to study nuclear receptor function. The availability of X-ray crystal data allows employment of virtual screening methods by which 3D structures of a virtual compound library are docked into the ligand-binding pocket of a receptor and the resulting binding modes are evaluated using a scoring function. Top-scored molecules are usually purchased from vendors and tested in vitro for example in transactivation assays as described above in order to validate the computational results. Once identified as real NR modulators, further experimental and computational studies can be conducted in order to investigate the mechanism of action or interaction partners in the cell.

A large number of successful virtual screening campaigns suggest that the various docking algorithms are well suited in order to identify NR agonists and antagonists. In case a NR structure is not available homology modelling techniques can be used in order to obtain structural data. For NRs this approach works quite well due to the highly conserved LBD structure and successful virtual screening campaigns against LBD models have been reported as well [184].

\subsubsection{Alternative Binding sites}

In recent years several alternative ligand-binding sites next to the ligand-binding pocket, located on the surface of the ligand-binding domain, have been discovered. The first identified alternative binding pocket is the co-activator binding site (AF-2 site), that can be targeted by small molecules in order to prevent NR-co-activator interactions, thereby antagonising the receptor. A second site has been identified on the surface of $A R$ (BF-3 site) that is conserved in related receptors (e.g. NURR1 and PPAR $\gamma$ ) and which allosterically communicates with the AF-2 site. Hence addressing BF-3 also disrupts co-activator binding (Buzon, Carbo et al. 2012). In addition, the LBD-DBD interface in the DNA-bound HNF4a homodimer provides a third alternative binding site for receptor modulators (Chandra, Huang et al. 2013). So far only very few AF-2 and BF-3 targeting compounds have been identified (Moore, Mayne et al. 2010). 
2 MATERIALS AND METHODS 


\subsection{Chemicals and biological reagents}

Ketoconazole and rifampicin were purchased from Tocris Bioscience (Bristol, UK); pimecrolimus, nelfinavir, pazopanib and paclitaxel were purchased from Selleckchem (Houston, TX); camptothecin was purchased from Sigma-Aldrich (Taufkirchen, Germany) and T0901317 and coumestrol from Enzo Life Sciences (Farmingdale, NY) and Cayman Chemical (Ann Arbor, MI), respectively. PK11195 and 6-(4chlorophenyl)imidazo[2,1-b][1,3]thiazole-5-carbaldehyde O-(3,4-dichlorobenzyl)oxime (hereafter called CITCO) were purchased from Tocris Bioscience (UK); gefitinib, pazopanib, sulconazole, miconazole, sunitinib, meclizine, clotrimazole and paclitaxel were purchased from Selleckchem (Germany). Dual-Glo Luciferase kit and the CellTiter-Glo kit were purchased from Promega (USA).

Cell culture medium and supplements were purchased from Capricorn Scientific (Ebsdorfergrund, Germany) and Life Technologies (Darmstadt, Germany). The SCREEN-WELL® FDA-approved drug library V2 was purchased from Enzo Life Sciences. Compound libraries were diluted in DMSO (10 mM) and store in LabCyte plates at $-20^{\circ} \mathrm{C}$ up to usage.

\subsection{Plasmids}

Eukaryotic expression plasmids encoding full-length human PXR (Geick et al 2001), isoform small PXR (Jeske et al 2017), RXRa (Hoffart et al $2012 \mathrm{Br} J$ Pharmacol), VDR and GR $\alpha$ (Burk et al 2005), FXR, LXRa and LXR $\beta$ (Piedade et al 2015), CAR1 (Burk et al 2002) and CAR3 (Arnold et al 2004) have all been described.

PXR mutants S247W and S208W/S247W/C284W were generated by site-directed mutagenesis of the full-length PXR expression plasmid using appropriate oligonucleotides and the Q5 Site-Directed Mutagenesis kit (New England Biolabs, Ipswich, MA). The mutations were verified by sequencing.

Expression plasmids encoding fusion proteins of GAL4-DNA binding domain (DBD) and the receptor interaction domains (RID) of steroid receptor coactivator-1 (SRC-1, residues 583-783) (Arnold et al 2004) and of silencing mediator of retinoid and thyroid hormone receptors (SMRT, residues 1109-1330) or helix 1 part of the LBD of PXR (residues 132-188) as well as expression plasmids encoding fusion proteins of the VP16 activation domain (AD) and the whole or part of the PXR-LBD (residues 
108-434 and 189-434, respectively) (Burk et al 2005) have been described. Also, plasmids encoding parts of the LBD domain of CAR (amino acids 105-348/105150/151-348) fusion with the VP16 activation domain (AD) have been previously described [94].

The following firefly luciferase reporter gene plasmids have been used before: CYP3A4 enhancer/promoter reporter gene plasmid pGL3-CYP3A4(7830/D7208364), hereinafter called CYP3A4 reporter, and pGL3(DR3) 3 Tk, with a trimer of CYP3A23 direct repeat (DR) 3 motif [185]; CYP2B6 enhancer/promoter reporter gene plasmid pB-1.6k/PB/XREM (Wang et al. 2003); reporter gene plasmid with a dimer of the MDR1-DR4(I) (Geick et al 2001); reporter gene plasmid with a tetramer of the glucocorticoid receptor (GR)-response element (RE) of tyrosine aminotransferase (Burk et al 2005); reporter gene plasmid containing a dimer of the consensus nuclear receptor inverted repeat (IR) 1 motif (Piedade et al 2015); GAL4dependent reporter gene plasmid pGL3-G5 (Arnold et al 2004). With the exception of the CYP3A4 and CYP2B6 reporters and pGL3-G5, the other four reporter gene plasmids harbour the thymidine kinase (TK) minimal promoter. The Renilla luciferase expression plasmids pRL-EF1a [186] and pRL-CMV (Promega, Madison, WI), with EF1 $\alpha$ and CMV promoters, respectively, have been used.

\subsection{Cell culture}

HepG2 cells (HB-8065, lot number 58341723, ATCC, Manassas, VA) were cultivated in minimal essential medium, supplemented with $10 \%$ FBS, $2 \mathrm{mM}$ L-glutamine, $100 \mathrm{U} / \mathrm{ml}$ penicillin and $0.1 \mathrm{mg} / \mathrm{ml}$ streptomycin. Cells were obtained at passage 74, propagated and used in experiments between passages 90 and 110. HEK293T cells were obtained from the Leibniz Institute DSMZ-German collection of microorganisms and cell cultures (Braunschweig, Germany). Cells were obtained at passage 19 and used in experiments between passages 25 and 40. Regular FBS was replaced by dextran-coated charcoal-stripped FBS in drug treatments. Cells were routinely checked for contamination with mycoplasma by PCR (VenorGeM Classic, Minerva Biolabs, Berlin, Germany). 


\subsection{High-throughput screening and dose-response studies}

\subsubsection{Transactivation assay for PXR antagonist screening}

HepG2 cells were transfected in suspension using JetPEI (Polyplus, Ilkirch, France) accordingly to manufacturer's conditions. Briefly 10,000 cells/well $(20 \mu \mathrm{l})$ were cotransfected with the expression plasmids for PXR (7.5 ng/well) and RXR (7.5 ng/well), the CPY3A4 reporter (70 ng/well), and pRL-EF1a (15 ng/well), in total of $100 \mathrm{ng}$ of DNA complex mixed with $0.2 \mu \mathrm{L}$ of JetPEI reagent per well. The suspension of transfected cells was seeded in 384 well plates (Greiner Bio-One, USA) and incubated overnight. After $24 \mathrm{~h}$ of transfection, cells were either treated with $0.1 \% \mathrm{DMSO}, 10 \mu \mathrm{M}$ rifampicin, or a mixture of $10 \mu \mathrm{M}$ rifampicin and $10 \mu \mathrm{M}$ of a library compound or $25 \mu \mathrm{M}$ ketoconazole as a positive control for PXR antagonism for additional $24 \mathrm{~h}$. The compound transfer was carried out using an Echo 550 Liquid Handler (PerkinElmer, Germany) from LabCyte stock plates with $10 \mathrm{mM}$ of compounds in DMSO.

\subsubsection{Transactivation assay for CAR inverse screening}

HEK293T cells were transfected in suspension using JetPEI (Polyplus-Transfection, France) according to manufacturer's conditions in normal media supplemented with $1 \%$ charcoal-stripped FBS media. For each well, 10,000 cells (in a volume of $25 \mu \mathrm{l}$ ) were co-transfected with the DNA/JetPEI complexes. DNA mixture included plasmids expressing CAR1 (7.5 ng) and RXR (7.5 ng), the reporter Firefly luciferase plasmid with CPY3A4 promoter/enhancer $(75 \mathrm{ng})$, and the normalisation control plasmid constitutively expressing Renilla Luciferase (10 ng). The suspension of transfected cells was seeded in 384 well plates (Greiner) and incubated overnight. After $16 \mathrm{~h}$ of transfection cells were treated with the vehicle control (DMSO, $0.1 \%$ ), standard control compound (PK11195, $10 \mu \mathrm{M})$ or a compound of the ENZO library (10 $\mu \mathrm{M})$, for additional $24 \mathrm{~h}$. The compound transfer was carried out using the Echo 550 Liquid Handler (PerkinElmer, Germany) from LabCyte stock plates with $10 \mathrm{mM}$ of compounds in DMSO. 


\subsubsection{Activity evaluation with dual luciferase system and data analyses}

Cell lysates were assayed for firefly and Renilla luciferase activities, respectively, using the DualGlo ${ }^{\circledR}$ Luciferase Kit (Promega) accordingly with the manufacturer indications with $20 \mu \mathrm{L}$ of each reagent, and luminescence was read by the EnVision multilabel plate reader (PerkinEImer, Germany). Normalised reporter activity (NRA) is calculated by firefly luciferase activity divided by the Renilla luciferase activity measured in the same well. The capacity of library compounds to modulate PXR activation of the CYP3A4 promoter/enhancer construct by rifampicin was illustrated as \% activation (\% act.) and calculated according to Zhu et al. 2004 [187] and calculated as follows:

$$
\% \text { act } .=\frac{(N R A \text { compound }-N R A \text { blank })}{(\text { NRA total }-N R A \text { blank })} \times 100 \%,
$$

Where NRA compound refers to the signal of compound plus rifampicin mixture treatment, NRA blank to the DMSO-only treatment and NRA total to the treatment with $10 \mu \mathrm{M}$ rifampicin only. CAR activation was normalised accordingly:

$$
\% \text { act. }=\frac{(\text { NRA compound })}{(N R A \text { blank })} \times 100 \% \text {, }
$$

Compounds which reduces \%act to less than $50 \%$ the original activity when compared to controls were considered hits and further selected for visual inspection. Compounds that had not reduced Renilla activity (a toxicity indicator) and presented some degree of novelty were subject to dose response experiments with a new synthesis batch. PXR dose response experiments were conducted in 384 well plates at 11 points 2 -fold dilution titration in DMSO, ranging from 25 to $0.025 \mu \mathrm{M}$. CAR hits were prepared in 384 well plates at 11 points 3-fold dilution titration in DMSO, ranging from 50 to $0.28 \mu \mathrm{M}$. In all cases, receptor activity is represented as fold change, which is defined as the normalisation between the experimental transfection against the values obtained from the mock cell-line and DMSO correction. Experimental data represent the mean of three independent transfection assays, each in technical triplicates. 


\subsection{NR specificity, mammalian two-hybrid and mutant PXR assays}

Transient transfections were performed in 24-well plates with $1.5 \times 10^{5}$ HepG2 cells per well, seeded the day before, using per well $1 \mu$ jetPRIME transfection reagent (Polyplus) and a plasmid DNA mixture consisting of $0.04 \mu \mathrm{g}$ of the respective NR expression plasmids, $0.3 \mu \mathrm{g}$ corresponding firefly luciferase reporter gene constructs, $0.01 \mu \mathrm{g}$ pRL-CMV, filled up with pUC18 to $0.5 \mu \mathrm{g}$. The following reporter gene plasmids were used for the NR specificity tests: DR3 reporter (VDR); consensus IR1 reporter (FXR); MDR1-DR4 reporter (LXRa, LXRß); tyrosine aminotransferase GRRE reporter (GRa); CYP3A4 reporter (PXR) and CYP2B6 reporter (CAR1, CAR3). Transfections for mammalian two-hybrid PXR co-repressor, coactivator and LBD assembly assays were done similarly, using the plasmids specified in the legend of Figure 3. In mutant PXR assays, respective PXR expression plasmids were combined with the CYP3A4 reporter as described above. $20 \mathrm{~h}$ after transfection, cells were treated with chemicals for another $24 \mathrm{~h}$. Then cells were lysed with 1x passive lysis buffer (Promega) and firefly and Renilla luciferase assays were performed as described (Geick et al. 2001; Piedade et al. 2015). Transfections were performed at least 4-times independently, each in technical triplicates.

\subsection{Cell viability assays}

Potential cell toxicity of the tested compounds was evaluated by ATP quantification using the CellTiter-Glo viability assay kit (Promega). HepG2 cells were seeded at 10,000 cells/well $(25 \mu \mathrm{l})$ in 384 well plates (Greiner) and incubated for $16 \mathrm{~h}$. Compounds to be tested (or DMSO) were added at concentrations aforementioned for an additional incubation of $48 \mathrm{~h}$ at $37^{\circ} \mathrm{C}$. After incubation, $20 \mu \mathrm{l}$ of CellTiter-Glo reagent were added and incubated for $30 \mathrm{~min}$ at room temperature protected from light. Luminescence was quantified by an EnVision plate reader (PerkinElmer, Germany) and compared to non-treated cells.

\subsection{Mammalian two-hybrid assay and CAR complementary assays.}

Transient transfections for the mammalian two-hybrid assay were employed for the analyses of CAR interactions, adapting a previously described protocol $[116,129,188]$. Instead of HepG2 cells on 24 well plates, HEK293T cells transfected 
in suspension with plasmid transfection reagent mix were plated at a density of $2 \times 10^{4}$ cells/well on 96 well white plates. Transfection comprehended a mix of $120 \mathrm{ng}$ of the reporter gene plasmid pGL3-G5, $8 \mathrm{ng}$ of each expression plasmid encoding GAL4 together with $65 \mathrm{ng}$ of VP16-CARsv1 fusion proteins and $4 \mathrm{ng}$ of CMV $\beta$-Renilla luciferase, as a reference, per well. Luciferase activities were analysed as described before.

\subsection{Human primary hepatocytes}

Human primary hepatocytes was performed collaboration and in situ with Dr. Oliver Burk from the Institute of Institute for Clinical Pharcology Dr. Margarete FischerBosch (Stuttgart, Germany), with the full support of his team.

Hepatocytes were prepared within the network of the hepacult GmbH (Regensburg, Germany) from tissue samples of liver resections, which were obtained from 4 patients of Caucasian ethnicity (GH41: female, age 37; GH42: female, age 52; GH43: female, age 32; GH44: male, age 55) who underwent partial hepatectomy because of focal nodular hyperplasia or liver metastases of colorectal carcinoma, as described previously [189]. Human liver tissue samples and annotated data were obtained and experimental procedures were performed in accordance with the Declaration of Helsinki and approved by the local ethics committee of the Ludwig-MaximiliansUniversity of Munich, within the framework of the non-profit foundation Human Tissue and Cell Research (HTCR, Regensburg, Germany), including the informed patient's full written consent [190]. Primary human hepatocytes were obtained as cell suspensions on ice within 16-20 h after preparation and cultivated and treated with chemicals as described before [172].

\subsection{RNA isolation and reverse transcription quantitative real-time PCR analysis}

Total RNA was isolated using the NucleoSpin RNA kit (Machery-Nagel, Düren, Germany), including on-column DNase I digest. Formaldehyde-agarose gel electrophoresis was applied to analyse RNA integrity. cDNA was synthesised as described previously [172]. 
Relative quantification analyses $\left(\Delta \Delta \mathrm{C}_{\mathrm{t}}\right)$ were performed in triplicates by TaqMan RTqPCR using the BioMark HD system and 48.48 Gene Expression Integrated Fluidic Circuits (Fluidigm, South San Francisco, CA), as described previously (Bitter et al. 2015). The following TaqMan gene expression assays (Life Technologies) have been used: Hs00184500_m1 (ABCB1), Hs01546975_gH (AKR1B10), Hs00946140_g1 (CYP2C8), Hs00604506_m1 (CYP3A4), Hs01005622_m1 (FASN), Hs99999902_m1 (RPLP0). The CYP2B6, EPHX1 and UGT1A3 assays have been described previously [129,191,192]. Data were analysed as described before [172] and gene expression levels normalised to corresponding 18S rRNA levels, as determined using the 18S rRNA assay previously described [192]. Assays demonstrated linearity between 375,000 and 37.5 copies, as determined by using serial dilutions of respective linearised cDNA plasmids, which were treated just as cDNA samples.

\subsection{Limited proteolytic digestion}

Radiolabeled PXR-LBD protein (residues 113-434) was synthesised in vitro using the TNT T7 Quick Coupled Transcription/Translation System (Promega) with $20 \mu \mathrm{Ci}{ }^{35} \mathrm{~S}$ methionine (specific activity $>1000 \mathrm{Ci} / \mathrm{mmol}$; Hartmann Analytic, Braunschweig, Germany) and $1 \mu \mathrm{g}$ of the small PXR expression plasmid in $50 \mu \mathrm{l}$ reactions. $5 \mu \mathrm{l}$ aliquots thereof were used in limited proteolytic digestion reactions as described [172]. Reactions were separated on 12\% SDS-polyacrylamide gels, which were subsequently stained with Coomassie, dried and exposed to BAS-IP MS 2325 imaging plates (Fuji, Kanagawa, Japan). Input PXR-LBD protein and protected proteolytic fragments were detected by scanning the imaging plates with the CR35 Bio radioluminography laser scanner (Raytest, Straubenhardt, Germany) and quantified using AIDA software version 4.50.010 (Raytest).

\subsection{TR-FRET for investigate LBP binding}

LanthaScreen TR-FRET PXR Competitive Binding Assay kit was obtained from Thermo Fisher Scientific (Darmstadt, Germany) and used according to manufacturer's recommendations with an assay time of $6 \mathrm{~h}$. Compounds were tested at a single concentration or dose-response $(30,10,3,1,0.3$ and $0.1 \mu \mathrm{M})$ and compared to DMSO solvent control (no inhibition) and Rifampicin (10 $\mu \mathrm{M}, 100 \%$ 
inhibition).TR-FRET emissions at 490 and $520 \mathrm{~nm}$ were measured after $340 \mathrm{~nm}$ excitation (all with $20 \mathrm{~nm}$ bandwidth). Emission signals collected on the Infinity M1000 PRO plate reader (TECAN, Männedorf, Switzerland) were used to calculate the 520:490 TR-FRET ratios.

\subsection{Molecular Docking}

\subsection{1 hPXR LBD}

Molecular docking was performed using GOLD version 5.4.1 (Cambridge Crystallographic Data Centre) and the ChemPLP scoring function. Preparation of Xray crystal structures and generation of ligand structures to be docked was conducted as described before (Jeske et al. 2017). For each compound, 50 docking runs were carried out. Non-default docking parameters have been described previously (Jeske et al 2017). Ligands were docked into the LBP and the AF-2 region of three X-ray crystal structures (LBP: PDB ID 1NRL, 1M13, 2O9I; AF-2: 1NRL, 2O9I, $5 A 86)$ respectively. For the AF-2 region, only $X$-ray crystal structures with cocrystallised co-activator peptide were considered and side chains of residues Lys252, Lys259, Lys277 and Glu427 were treated as partially flexible using a rotamer library in GOLD. The docking site for AF-2 was defined by residues interacting with the cocrystallised SRC-1 co-activator peptide.

\subsection{2 hCAR LBD}

Molecular docking was performed using GOLD version 5.4.1 (Cambridge Crystallographic Data Centre). Selection of the optimal scoring function was conducted by redocking of co-crystallised ligands into both X-ray crystal structures (PDB IDs 1XV9, 1XVP). Protein structures were prepared using the software package Molecular Operating Environment version 2015.1001 (MOE, Chemical Computing Group Inc.). Ligand structures to be docked were either taken from other chains of the PDB entry (1XVP) or generated within MOE (1XV9), followed by minimization using Amber10:EHT force field with implicit solvation model (R-Field). Compounds were docked into a sphere of $8 \AA$ radius around the position of the 
original ligand. For each compound, 30 docking runs were carried out. The early termination option was switched off. Redocking of co-crystallised ligands into the CAR LBD revealed the scoring function ChemPLP to be best suited for docking, resulting in top-ranked docking poses with heavy atom root-mean-square deviation (RMSD) below $1 \AA$ for both test cases. Compounds emerging from the highthroughput screening were docked into 1XVP. Three-dimensional structures of compound structures were prepared in MOE as described before. Docking into the AF-2 region was performed using the same GOLD parameters within a sphere of $10 \AA$ radius centred on oxygen atom of the main chain of Leu172.

\subsection{Data analyses}

Calculation of Z prime (Z') for HTS validation was performed according to Zhang [193] and plates were considered valid for further analyses when Z'>0.5. Experimental data represent means \pm standard error of the mean (SEM) of at least 3 independent experiments or medians with interquartile ranges. Medians were used only with primary human hepatocytes, as independent experiments were performed here with cultures from different donors. Statistical comparisons were performed with ordinary or repeated measures t-test, one-way or two-way ANOVA or Friedman test, using respective posthoc tests for multiple comparisons against controls, as recommended by the analysis software and described in the figure legends. $I_{50}$ values were determined by a non-linear fit of dose response using the equation for sigmoidal dose response with variable slope. All calculations, except for Z', were done with GraphPad Prism 7.01 (GraphPad software, La Jolla, CA, USA). 
3 RESULTS 


\subsection{Identification of novel PXR antagonists}

Using previously described modifications (Zhu et al 2004; Ratajewski et al 2015), we adapted a PXR transactivation assay, which relies on the transient co-transfection of a human PXR expression plasmid together with a CYP3A4 reporter [185] for the 384well plate format. Transiently transfected HepG2 cells, treated with rifampicin at $10 \mu \mathrm{M}$, showed 3-fold induction of reporter gene activity and co-treatment with $25 \mu \mathrm{M}$ ketoconazole completely inhibited PXR-dependent activation (Figure 3A, inset). Thus, the signal-to-background ratio was 3 and ' $Z^{\prime}$ was 0.58 . ' Z' is considered acceptable if above 0.5 [177].

Figure 3 - Identification of novel PXR antagonists
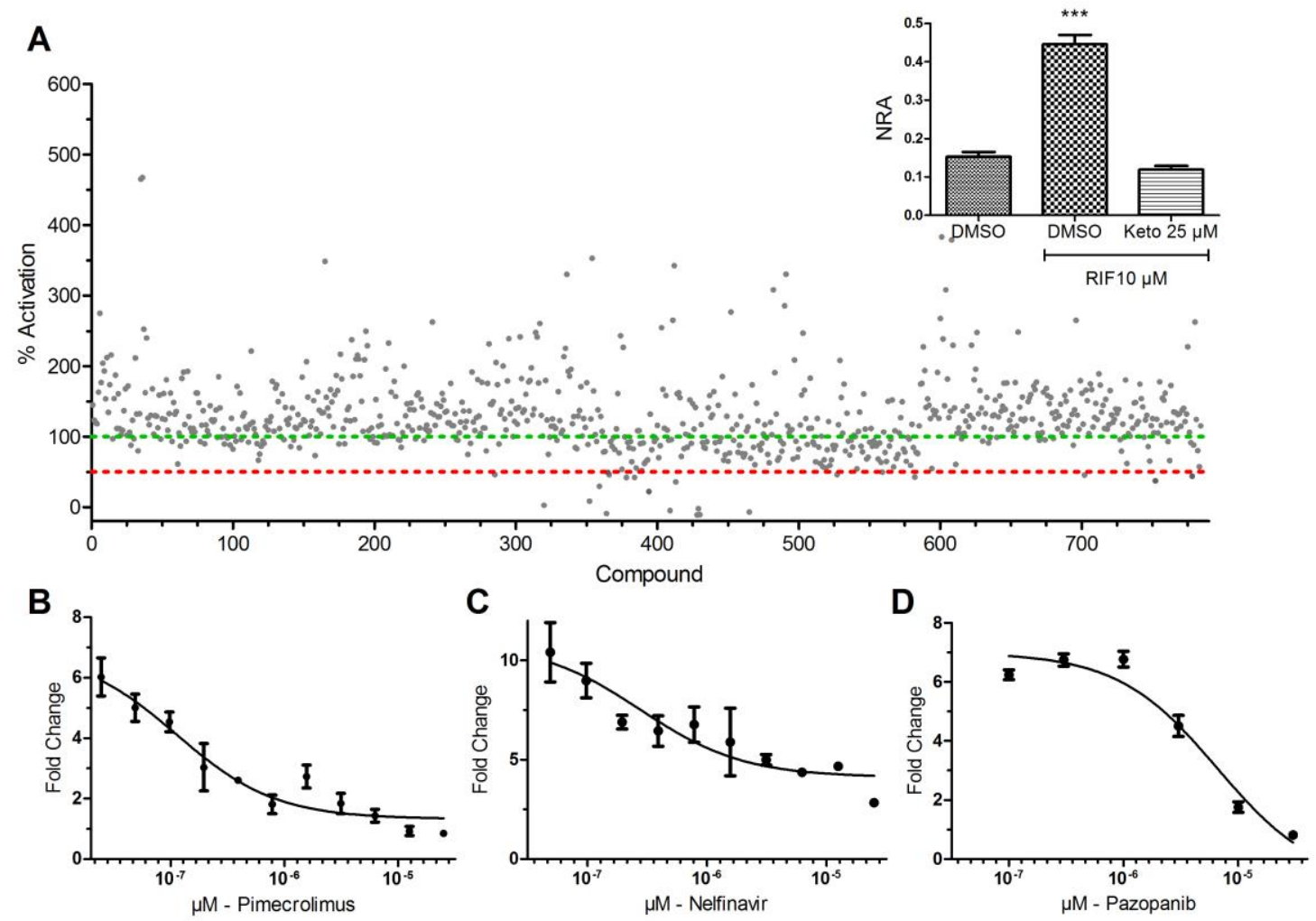
A) HepG2 cells, which were co-transfected with CYP3A4 reporter and expression plasmids encoding human PXR and RXRa were treated for $24 \mathrm{~h}$ with $0.1 \%$ DMSO, $10 \mu \mathrm{M}$ rifampicin or a mixture of $10 \mu \mathrm{M}$ rifampicin and $10 \mu \mathrm{M}$ of the respective library compounds. Points shows normalized reporter activities of cells treated with individual mixtures of rifampicin and respective library compounds, relative to the activity of cells treated with rifampicin only, which was set as $100 \%$ and shown as green dotted line. The red dotted line represents the $50 \%$ inhibition threshold. (Inset) Columns show means \pm SEM $(\mathrm{N}=3)$ of normalized reporter activities (NRA) of the indicated control treatments with $0.1 \%$ DMSO only (vehicle), $10 \mu \mathrm{M}$ rifampicin and a mixture of $10 \mu \mathrm{M}$ rifampicin and $25 \mu \mathrm{M}$ ketoconazole (Keto), which were present on all screening plates. Statistical significant differences of treatments versus DMSO control, as analysed by one-way ANOVA with Dunnett's post-test, are indicated by asterisks ( $\left.{ }^{* * *}, p<0.001\right)$. (B-D) PXR antagonist hit confirmation by co-transfecting HepG2 cells, as described above, and treating them with increasing concentrations of pimecrolimus (B), pazopanib (C), or nelfinavir (D), as a mixture with $10 \mu \mathrm{M}$ rifampicin

All 784 compounds of the SCREEN-WELL® FDA-approved drug library V2 were screened for modulation of the rifampicin-induced activation of PXR. Figure $3 \mathrm{~A}$ shows that $410(52.3 \%)$ of the tested compounds modulated the induction by rifampicin by less than $30 \%$, which we considered as non-significant. Altogether 314 compounds $(40.1 \%)$ further increased induction by rifampicin, among them several known PXR agonists such as rifampicin, spironolactone, nabumetone, thalidomide or lovastatin. 60 compounds (7.7\%) antagonised rifampicin-activated PXR, of which 22 showed $\geq 50 \%$ inhibition. None of the five known antagonists that were included in the compound library showed inhibitory effect at $10 \mu \mathrm{M}$, but either resulted in nonsignificant modulation (residual activities: ketoconazole, $90 \%$; fluconazole, $124 \%$; metformin, $98 \%$ ) or even enhanced activation by rifampicin (itraconazole, $229 \%$; leflunomide, $200 \%$ ). Of the 22 compounds with potent PXR inhibition (Table 1), eight revealed as cytotoxic on HepG2 cells at $10 \mu \mathrm{M}$, whereas six specifically increased Renilla luciferase activity used for normalisation. Another five compounds did not confirm in dose-response experiments. 
Table 1 - Summary of antagonist candidates with $\geq 50 \%$ inhibition in the primary screening.

\begin{tabular}{|c|c|c|}
\hline Compound & Residual Activity (\%) & Effect \\
\hline Fosphenytoin & -11 & Increased the Renilla reporter activity alone \\
\hline Gemifloxacin & -11 & Toxic to HepG2 cells \\
\hline Ribavirin & -9 & Increased the Renilla reporter activity alone \\
\hline Decitabine & -7 & Toxic to HepG2 cells \\
\hline Tinidazole & -5 & Not confirmed in dose-response experiments \\
\hline Actinomycin D & -2 & Toxic to HepG2 cells \\
\hline Pentoxifylline & 3 & Not confirmed in dose-response experiments \\
\hline Cilostazol & 9 & Not confirmed in dose-response experiments \\
\hline Colchicine & 22 & Toxic to HepG2 cells \\
\hline Fingolimod & 29 & Toxic to HepG2 cells \\
\hline Topotecan & 36 & Toxic to HepG2 cells \\
\hline Pazopanib & 37 & $\mathrm{IC}_{50}=4.0 \mu \mathrm{M}$ \\
\hline Clofazimine & 42 & Toxic to HepG2 cells \\
\hline Cladribine & 42 & Not confirmed in dose-response experiments \\
\hline Loteprednol & 43 & Increased the Renilla reporter activity alone \\
\hline Pimecrolimus & 44 & $\mathrm{IC}_{50}=5.6 \mu \mathrm{M}$ \\
\hline Sorafenib & 46 & Toxic to HepG2 cells \\
\hline Alitretinoin & 46 & Increased the Renilla reporter activity alone \\
\hline Raloxifene & 46 & Increased the Renilla reporter activity alone \\
\hline Efavirenz & 46 & not confirmed in dose-response experiments \\
\hline Nelfinavir & 49 & $\mathrm{IC}_{50}=0.6 \mu \mathrm{M}$ \\
\hline Cefdinir & 50 & Increased the Renilla reporter activity alone \\
\hline
\end{tabular}

Residual activity is expressed in terms of measurements of transfected HepG2 cells, treated with $10 \mu \mathrm{M}$ of rifampicin and $10 \mu \mathrm{M}$ of the mentioned compound. Dose response experiments for determination of $\mathrm{IC}_{50}$ values were conducted in presence of $10 \mu \mathrm{M}$ rifampicin.

Finally, three drugs confirmed as potent PXR antagonists: pimecrolimus, $\left(\mathrm{IC}_{50}=5.6 \mu \mathrm{M}\right)$, nelfinavir $(0.6 \mu \mathrm{M})$ and pazopanib $(4.0 \mu \mathrm{M})$, respectively (Figure 3BD). Nelfinavir turned out to be toxic for HepG2 cells at $50 \mu \mathrm{M}$, while pimecrolimus and pazopanib did not show any toxic effect up to this concentration (Figure 4). 
Figure 4 - Cell viability of PXR antagonists
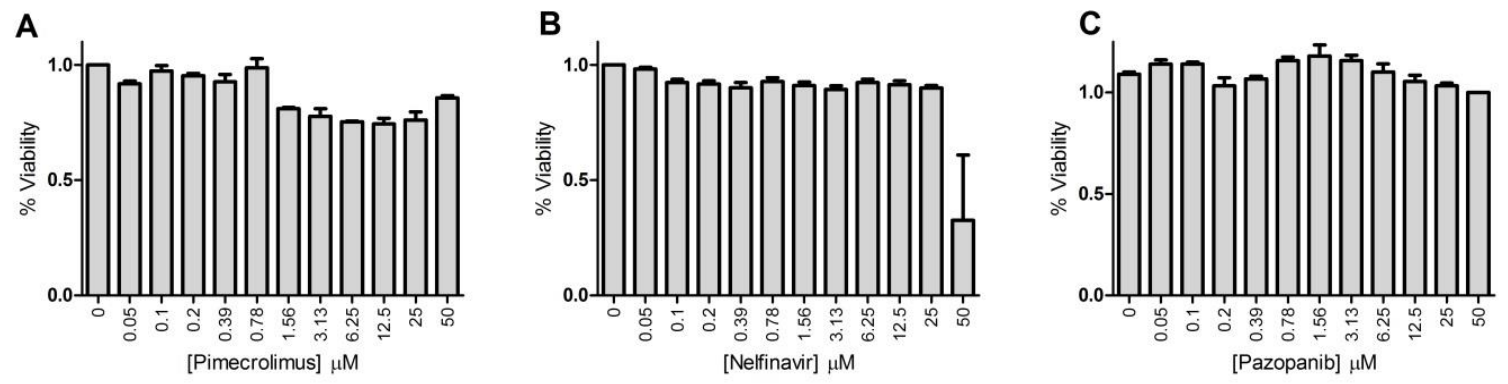

(A-C) HepG2 cells were seeded and treated next day with increasing concentrations of pimecrolimus (A), nelfinavir (B) or pazopanib (C) or $0.1 \%$ DMSO for additional $48 \mathrm{~h}$. Columns represent means $\pm \operatorname{SEM}(N \geq 3)$.

\subsubsection{Nuclear receptor selectivity of novel PXR antagonists}

In order to evaluate receptor selectivity of the novel PXR antagonists, liganddependent activation of a panel of NRs was studied using respective promoter reporter genes. The functionality of the assays was confirmed by receptor activation using specific agonists, pimecrolimus did not show receptor-dependent effects, with the exception of a slight activation of CAR1 and CAR3 by 1.4- and 1.3-fold, respectively. But even these effects are likely to result from CAR-independent activation of the CYP2B6 reporter (Figure 5). In accordance with our own observations and literature data [194], nelfinavir alone activated PXR. Additionally, the compound showed a 2-fold activation of FXR and a 2-fold inhibition of CAR1. Pazopanib did not show any receptor-dependent effects, but prominently inhibited receptor-independently the activities of thymidine kinase minimal -promoter-based reporter genes, as well as activated receptor-independently the CYP2B6 reporter. 
Figure 5 - Specificity of novel PXR antagonists.
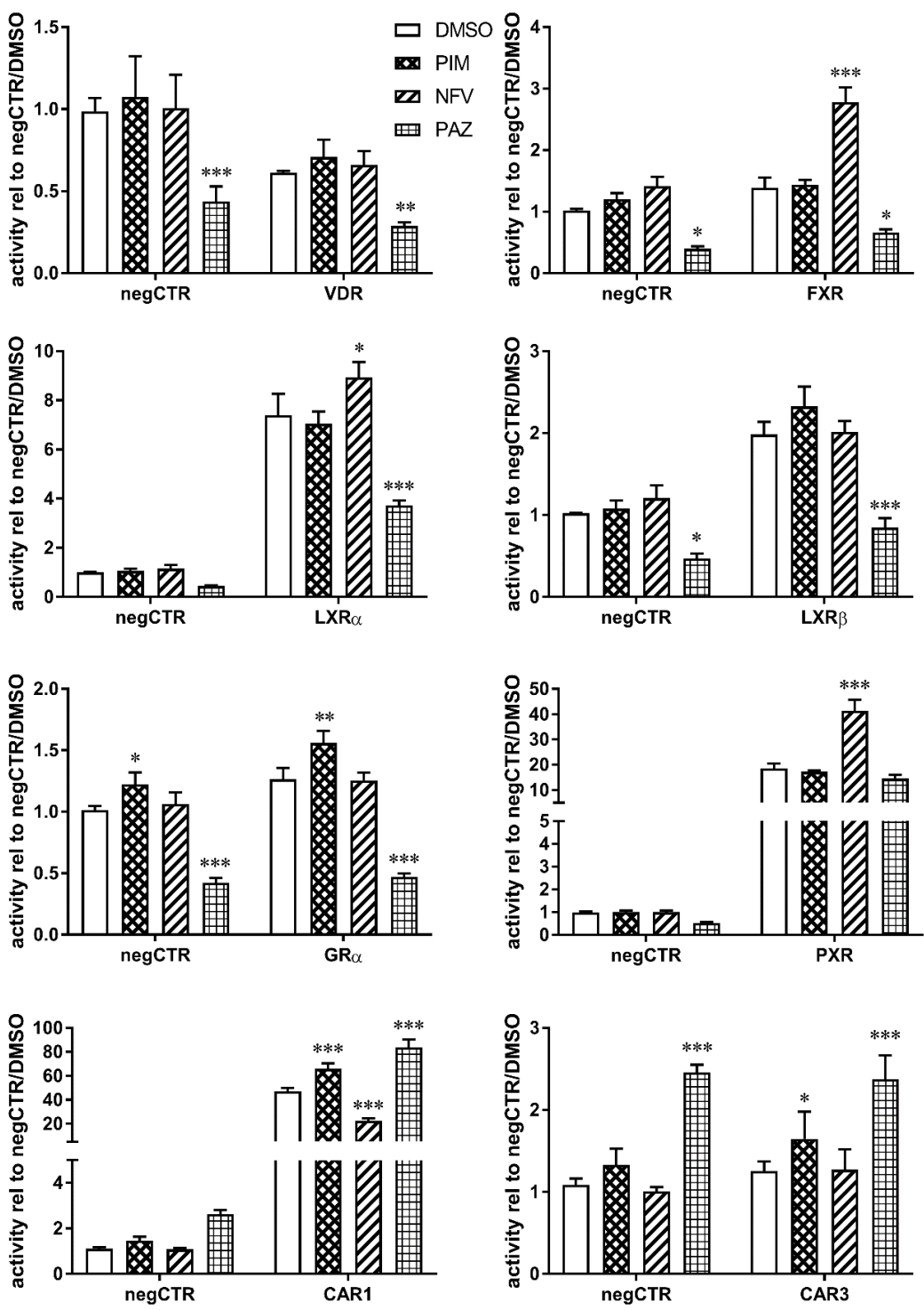

HepG2 cells were transfected with either empty vector pcDNA3 (negCTR) or expression plasmids encoding the indicated human nuclear receptors and treated for $24 \mathrm{~h}$ with $10 \mu \mathrm{M}$ pimecrolimus (PIM), nelfinavir (NFV), pazopanib (PAZ) or $0.1 \%$ DMSO. Columns show means \pm SEM $(N=4)$ of normalized luciferase activity of co-transfected corresponding reporter gene plasmids (as specified in Materials and Methods), relative to the activity of cells transfected with pcDNA3 and treated with DMSO only. Significant differences to respective treatments with DMSO were analysed by repeated measures twoway ANOVA with Dunnett's multiple comparisons test. ${ }^{*} p<0.05 ;{ }^{* *} p<0.01 ;{ }^{* * *} p<0.001$

3.1.2 Novel antagonists disrupt co-regulator protein interactions with PXR while differentially inducing PXR-LBD assembly

Furthermore, we investigated the ligand-dependent interactions with co-regulatory proteins, as well as the intramolecular conformational changes of the PXR-LBD, in form of the LBD assembly assay. The strong constitutive interaction of PXR with co- 
repressor SMRT was reduced by rifampicin and the known antagonist camptothecin. All three newly identified antagonists also interfered with the interaction of PXR with SMRT (Figure 6A). In addition to co-repressor release, agonist binding results in recruitment of co-activators to $\mathrm{PXR}$, as exemplified by the rifampicin-dependent recruitment of co-activator SRC-1 (Figure 6B). Neither the known antagonist camptothecin nor pazopanib promoted SRC-1 recruitment, whereas pimecrolimus and nelfinavir showed some effect, which however was not significant for the latter (Figure 6B). As expected, all newly identified PXR antagonists interfered with the rifampicin-induced recruitment of SRC-1, similar as camptothecin (Figure 6B).

Figure 6 - PXR antagonists interfere with co-factor interaction and differentially induce LBD assembly.

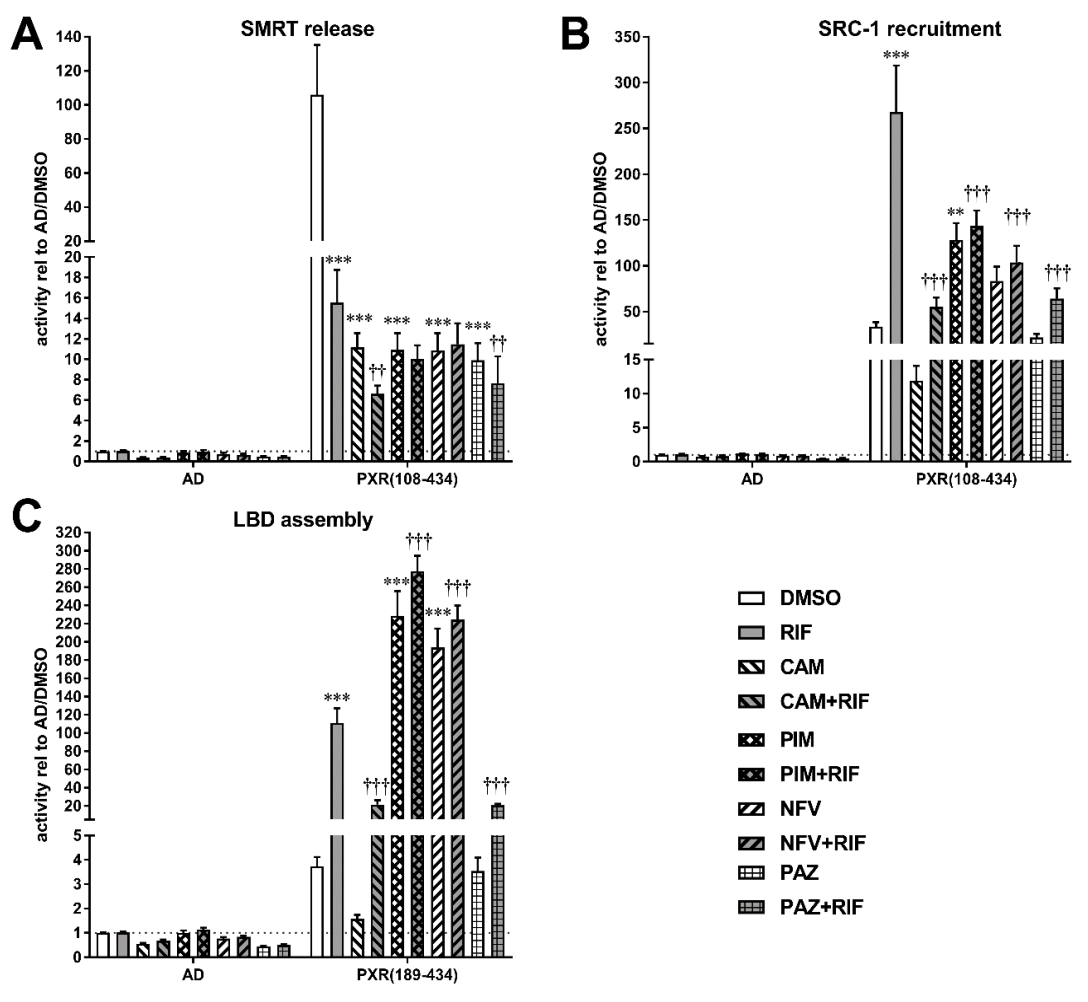


HepG2 cells were co-transfected with expression plasmids encoding VP16-AD/PXR-LBD(108-434) fusion protein or empty vector pVP16-AD and expression plasmids encoding fusion proteins of $(A)$ GAL4-DBD/SMRT-RID or (B) GAL4-DBD/SRC-1-RID. For the LBD assembly assay (C), combinations of expression plasmids encoding GAL4-DBD/PXR-LBD(132-188) and VP16-AD/PXR-LBD(189-434) or empty vector pVP16-AD were transfected. Transfected cells were treated with $0.1 \%$ DMSO, $1 \mu \mathrm{M}$ camptothecin (CAM), $10 \mu \mathrm{M}$ pimecrolimus (PIM), nelfinavir (NFV) or pazopanib (PAZ), with or without $10 \mu \mathrm{M}$ rifampicin (RIF) for $24 \mathrm{~h}$. Columns show means \pm SEM $(N \geq 4)$ of normalized luciferase activity of the co-transfected pGL3-G5, relative to the activity of cells transfected with pVP16-AD and treated with DMSO only. Significant differences to respective treatments with DMSO (asterisks, exclusively for single compound treatments) or with rifampicin only (daggers, exclusively for rifampicin co-treatments) were analysed by repeated measures $(A, B)$ or ordinary $(C)$ two-way ANOVA with Dunnett's multiple comparisons test. $\dagger p<0.05 ;{ }^{* *}, \dagger \dagger p<0.01 ;{ }^{* * *}, \dagger^{+} \dagger p<0.001$.

Nuclear receptor LBD assembly assays likewise identify agonists as well as antagonists [195]. Thus, these assays may be regarded as cellular equivalents of respective in vitro ligand binding assays. Figure $6 \mathrm{C}$ shows that pimecrolimus and nelfinavir induced the assembly of the PXR LBD, even more, pronounced than rifampicin, while pazopanib did not. Camptothecin, which has previously been shown not to bind to the LBP, did not induce the assembly of the PXR LBD. However, the compound interfered with the induction of the PXR LBD assembly by rifampicin as did pazopanib. These data suggest that pimecrolimus and nelfinavir may bind to the LBP, while pazopanib may not.

\subsubsection{Pimecrolimus and pazopanib inhibit the constitutive activity of LBP-filled PXR mutants}

Antagonists may bind additionally or exclusively to sites on the PXR LBD outside of the LBP, as was shown for coumestrol and suggested for camptothecin, respectively (Wang et al 2008; Chen et al 2010). Thus, we analysed whether the novel PXR inhibitors still antagonise the receptor, if its LBP is filled by mutation of critical amino acids to bulky tryptophan residues. The mutations Ser247Trp and Ser208Trp/Ser247Trp/Cys284Trp efficiently prevent ligand-dependent activation, while concomitantly resulting in the high constitutive activity of the receptor (Wang et al 2008). Pimecrolimus and pazopanib, as well as the known antagonist camptothecin, inhibited the high constitutive activity of the single and triple mutants, whereas nelfinavir did not (Figure 7). These data suggest that pimecrolimus and pazopanib, in contrast to nelfinavir, seem to bind either additionally or exclusively to a second site outside of the LBP. 
Figure 7 - Pimecrolimus and pazopanib, but not nelfinavir, inhibit LBP-filled PXR mutants.

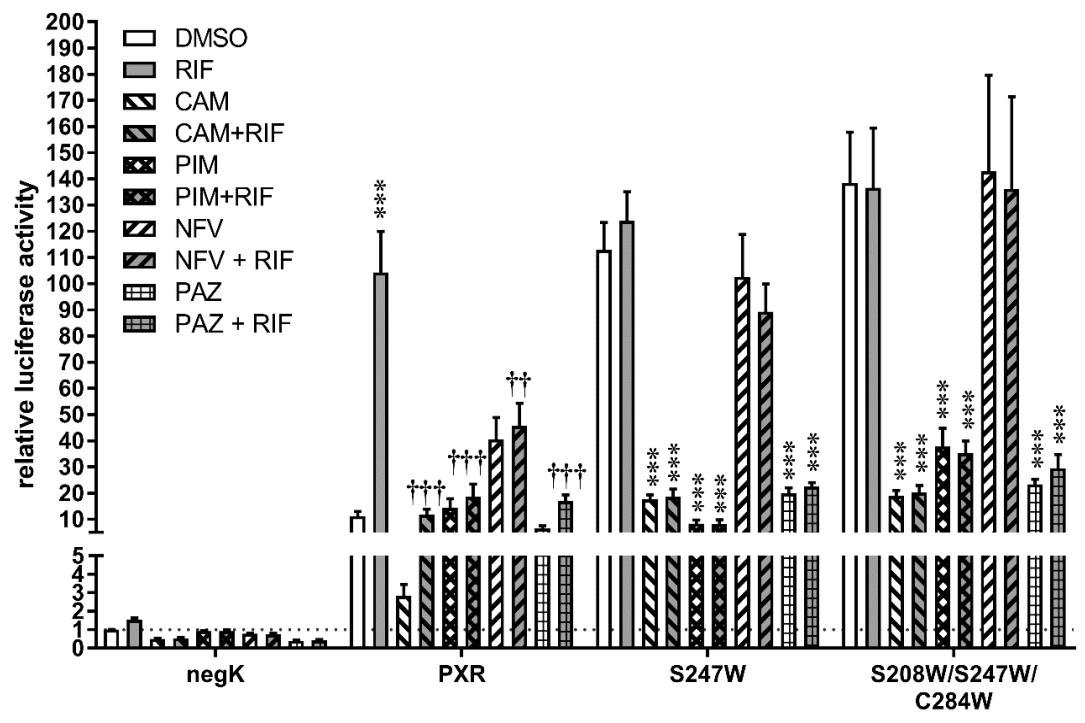

HepG2 cells, which were transfected with empty vector pcDNA3 (negCTR) or expression plasmids encoding wild type human PXR or the indicated single or triple mutants, were treated with $0.1 \%$ DMSO, $1 \mu \mathrm{M}$ camptothecin (CAM), $10 \mu \mathrm{M}$ pimecrolimus (PIM), nelfinavir (NFV) or pazopanib (PAZ), with or without $10 \mu \mathrm{M}$ rifampicin (RIF) for $24 \mathrm{~h}$. Columns show means \pm SEM ( $N \geq 4)$ of normalized luciferase activity of co-transfected CYP3A4 reporter, relative to the activity of cells transfected with pcDNA3 and treated with DMSO only. Significant differences to respective treatments with DMSO (asterisks) or with rifampicin only (daggers, exclusively for rifampicin co-treatments in wild type PXR) were analysed by two-way ANOVA with Dunnett's multiple comparisons test. †† $p<0.01$; ${ }^{* *}$, ††† $p<0.001$.

\subsubsection{Novel PXR antagonists bind directly to the PXR LBD}

Direct binding of ligands induces conformational changes in nuclear receptor LBDs, which alter the accessibility of protease cleavage sites. Limited proteolytic digestion assays have thus been used to demonstrate direct ligand binding in vitro [196]. Figure 8 shows that pre-incubation of the $36 \mathrm{kDa}$ PXR-LBD protein with the known agonist T0901317, as well as with pimecrolimus and nelfinavir resulted in the protection of three proteolytic fragments of 32,26 and $23 \mathrm{kDa}$ from limited proteolytic digestion, thereby indicating a direct binding of these compounds to the PXR LBD. In contrast, pazopanib and the already known antagonist camptothecin did not result in any protection. The antagonist coumestrol protected only the $32 \mathrm{kDa}$ fragment. 
Figure 8 - Pimecrolimus and nelfinavir bind directly to PXR.

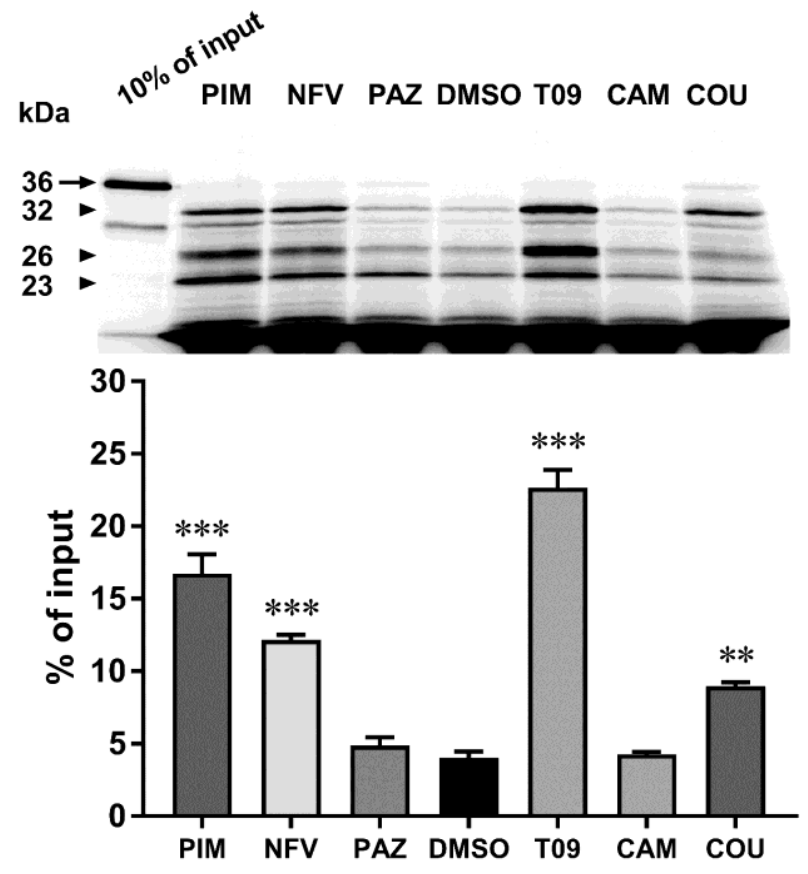

Limited proteolytic digestion analysis of PXR-LBD, pre-incubated with $100 \mu \mathrm{M}$ pimecrolimus (PIM), nelfinavir (NFV) or pazopanib (PAZ), $2.5 \%$ DMSO, $30 \mu \mathrm{M}$ T0901317 (T09) or camptothecin (CAM) or $250 \mu \mathrm{M}$ coumestrol. Upper panel shows representative results, with $36 \mathrm{kDa}$ input PXR LBD (arrow), and protected 32, 26 and $23 \mathrm{kDa}$ proteolytic fragments (arrowheads). Lower panel shows respective densitometric quantifications of the sum of the three protected fragments. Columns show means \pm SEM $(N=3)$, calculated with respect to input. Significant differences to respective pre-incubations with DMSO (asterisks) were analysed by one-way ANOVA with Dunnett's multiple comparisons test. ${ }^{* *}, p<$ $0.01 ;{ }^{* * *}, p<0.001$.

In addition, a TR-FRET assay was employed to study the competitive binding of the antagonists to the PXR LBP. For rifampicin we determined an $\mathrm{EC}_{50}$ value of $27.2 \mu \mathrm{M}$ after $6 \mathrm{~h}$ (Figure 9A); therefore $50 \mu \mathrm{M}$ was employed in the next experiments for ensuring maximum inhibition. PXR antagonists and two agonists (rifampicin and paclitaxel) were evaluated at $50 \mu \mathrm{M}$ after $6 \mathrm{~h}$ incubation with the PXR-fluormone complex (Figure 9B). All PXR antagonists showed weaker binding to the LBP in comparison to rifampicin. Nelfinavir and pimecrolimus showed similar levels to paclitaxel, while pazopanib revealed the weakest displacement. Pazopanib happens to fluoresce in the specific wave-lengths utilised to quantify TR-FRET, therefore its displacement of PXR-fluormone an artefact due to quenching of signal Figure 10. 
Figure 9 - PXR antagonists reveal different LBD-binding.

A

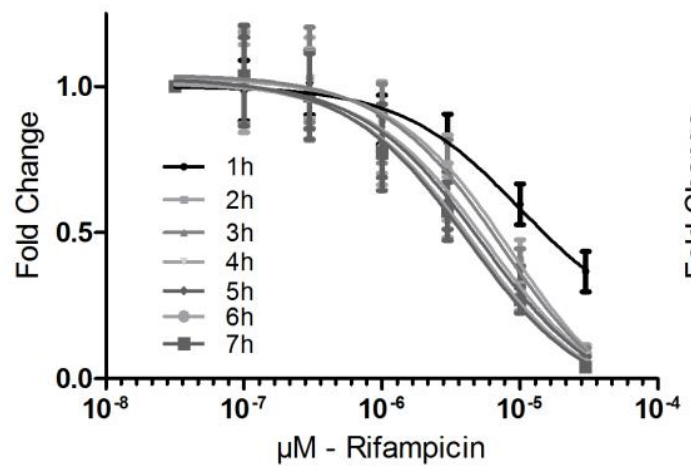

B

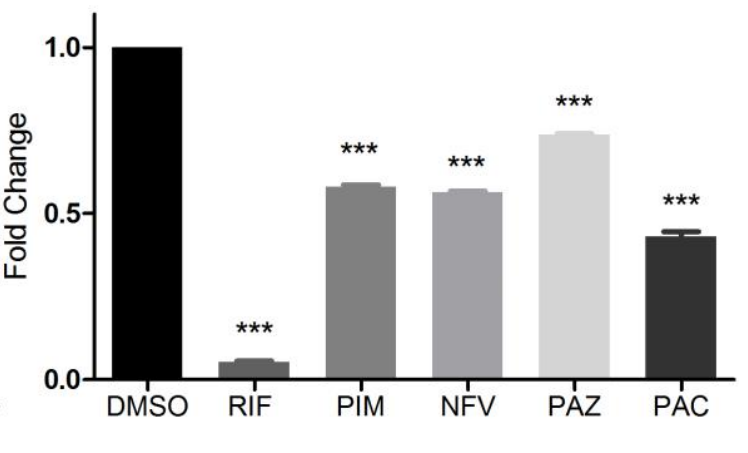

TR-FRET assay was employed to study binding of the antagonists to the PXR LBP, by displacing a fluormone substrate. Ratio between complex PXR-fluormone and free PXR was measured by emitted fluorescence at 515 and $490 \mathrm{~nm}$, upon $340 \mathrm{~nm}$ excitation, respectively. Emission ratios were normalised towards the controls Rifampicin $(50 \mu \mathrm{M})$ and vehicle (DMSO, $1 \%)$. A) Rifampicin (RIF) binding was evaluated in dose-response $(30,10,3,1,0.3$ and $0.1 \mu \mathrm{M})$ through the course of $7 \mathrm{~h}$, being $6 \mathrm{~h}$ chosen as the best incubation time in terms of S/B and slope. B) Competitive binding of agonists rifampicin (RIF) and paclitaxel (PAC) as well as antagonists pimecrolimus (PIM), nelfinavir (NFV) and pazopanib (PAZ) was evaluated after $6 \mathrm{~h}$ incubation (at $50 \mu \mathrm{M}$ ) with the PXR-fluormone complex and the displacement was quantified. Significant differences to respective treatments with DMSO (asterisks) were analysed by multiple paired t-test with Dunnett's multiple comparisons test. ${ }^{\star * *}, p<0.001$.

Figure 10 - PXR antagonist fluorescence emission upon specific excitation.

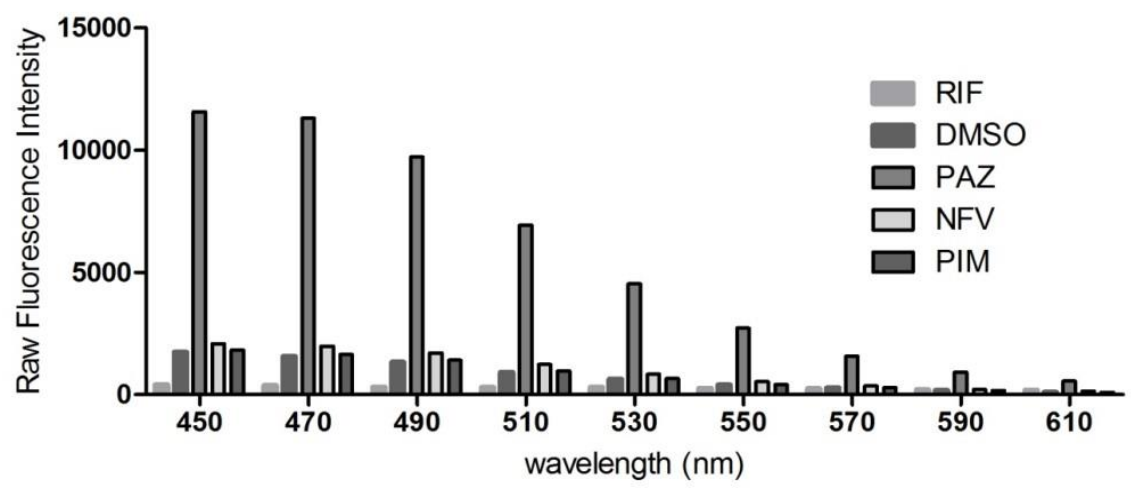

Fluorescence intensity emission (450 - 610 nm) of compounds were evaluated to their emissions was evaluated after specific excitation $(340 \mathrm{~nm})$. Fluorescence intensity of agonist rifampicin (RIF) and antagonists pimecrolimus (PIM), nelfinavir (NFV) and pazopanib (PAZ) was evaluated after $6 \mathrm{~h}$ incubation (at $50 \mu \mathrm{M})$ within TR-FRET assay buffer.

\subsubsection{Molecular docking of novel antagonists into LBP and AF2 region of PXR}

Potential binding modes of all three compounds within the LBP and the AF-2 region of PXR were evaluated using molecular docking. Together with some already known 
ligands, the novel antagonists were docked into the LBP of three different PXR X-ray crystal structures (PDB ID 1NRL, 2O9I, 1M13). Docking of the large compound pimecrolimus into the LBP resulted in highly unfavourable docking scores for 2091 and $1 \mathrm{NRL}$ and only moderate scores for $1 \mathrm{M} 13$ (Table 2). In contrast, docking scores for nelfinavir and pazopanib indicate favourable binding in all LBPs. Within the LBP, pimecrolimus and nelfinavir each formed a single hydrogen bond while pazopanib formed two hydrogen bonds (Figure 11A-C, Table 3).

Figure 11 - Suggested binding Modes of PXR antagonists.

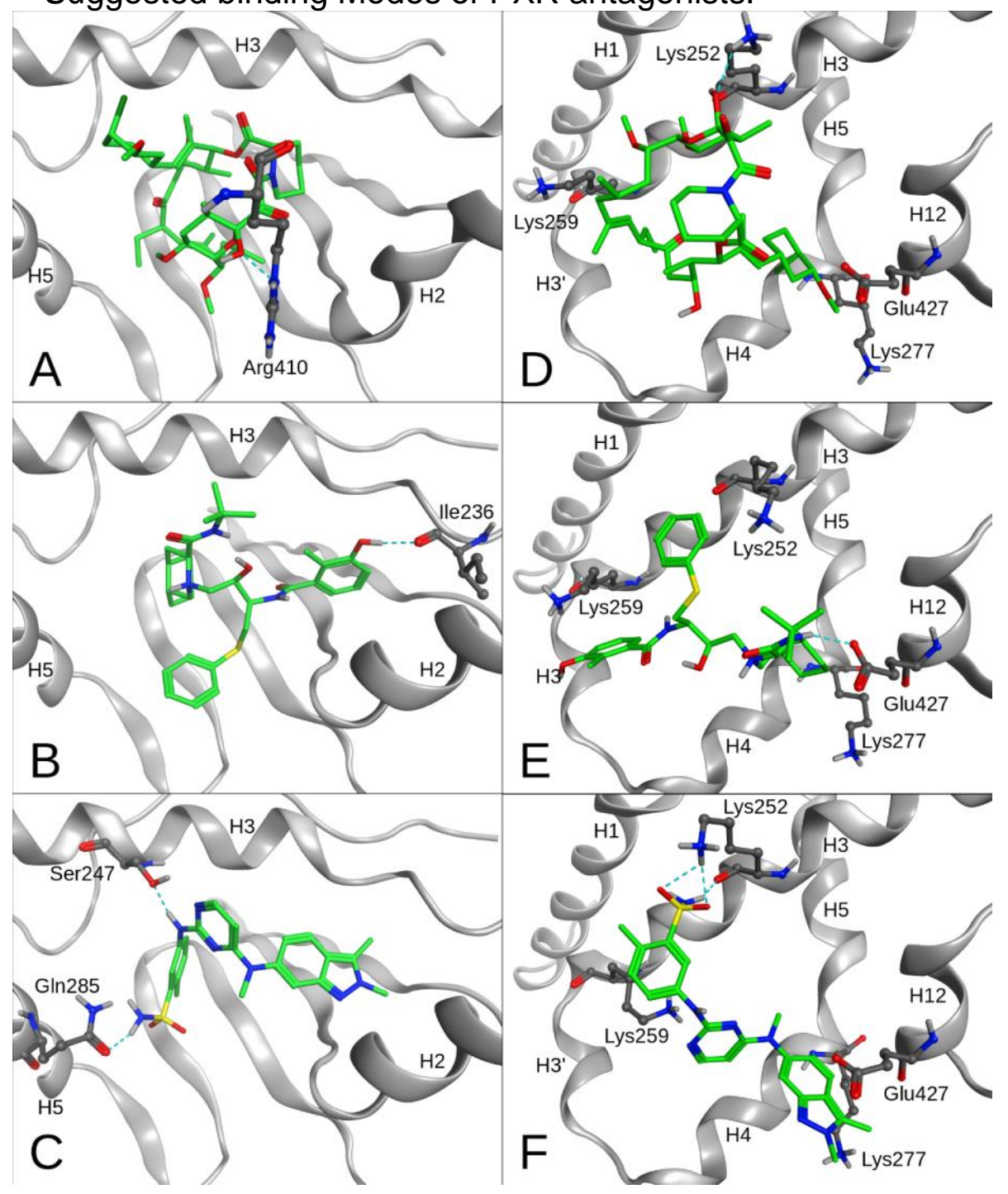

Top-ranked docking poses of newly identified antagonists in the LBP (A, pimecrolimus; B, nelfinavir; $C$, pazopanib) and the AF-2 region (D, pimecrolimus; $E$, nelfinavir; $F$, pazopanib) of the PXR LBD. Carbon atoms of docked ligands are shown in green. Selected amino acid residues are shown in balland-stick representation with carbon atoms in grey. The LBD secondary structure is indicated in grey ribbon. Hydrogen bonds are shown as blue dotted lines. 
When docked into the AF-2 site of X-ray crystal structures co-crystallised with a coactivator RID (PDB 1NRL, 2O9I, 5A86), docking scores for nelfinavir and pazopanib were lower compared to the LBP-bound poses while the docking score for pimecrolimus was higher (Table 2). Top-ranked docking poses of pimecrolimus and nelfinavir revealed a single hydrogen bond with PXR. The docking pose of pazopanib showed salt bridge formation between its sulfonamide moiety and the Lys252 side chain as well as an additional hydrogen bond with the Lys252 backbone carbonyl moiety (Figure 11F, Table 3), while nelfinavir did not (Figure 11E, Table 3).

In addition, we conducted an energy minimisation of best-scored protein-ligand complexes in order to remove unfavourable interactions. Calculation of the interaction energies for each compound with PXR suggested slightly more favourable binding of pimecrolimus and nelfinavir to the LBP and strong preference of pazopanib for the AF-2 site (Table 2). 
Table 2 - Docking scores of top-ranked poses of newly identified PXR inhibitors

\begin{tabular}{|c|c|c|c|c|c|c|c|c|}
\hline \multicolumn{2}{|c|}{ Compound } & \multicolumn{7}{|c|}{ LBP } \\
\hline \multirow[t]{2}{*}{ Name } & \multirow[t]{2}{*}{ MW } & \multicolumn{2}{|c|}{ 209I } & \multicolumn{2}{|c|}{ 1NRL } & \multicolumn{2}{|c|}{$1 \mathrm{M} 13$} & \multirow[t]{2}{*}{ Energy } \\
\hline & & ND1 & NE2 & ND1 & NE2 & ND1 & NE2 & \\
\hline Pimecrolimus & 810.5 & -26.4 & -25.0 & -20.9 & -20.0 & 36.4 & 37.7 & -40.6 \\
\hline Nelfinavir & 567.8 & 104.0 & 103.6 & 101.1 & 98.0 & 101.4 & 97.9 & -50.7 \\
\hline Pazopanib & 437.5 & 87.9 & 90.9 & 85.6 & 85.0 & 85.2 & 83.8 & -37.3 \\
\hline Ketoconazole (2R4S) & 531.4 & 99.4 & 101.3 & 89.1 & 88.7 & 88.7 & 88.6 & -31.9 \\
\hline Ketoconazole (2S4R) & 531.4 & 100.1 & 101.8 & 89.7 & 89.6 & 86.9 & 93.2 & -5.5 \\
\hline SR12813 & 504.5 & 78.6 & 82.8 & 90.0 & 84.0 & 77.7 & 76.8 & -78.9 \\
\hline Rifampicin & 822.9 & -47.4 & -46.6 & -36.0 & -34.4 & 24.2 & 21.6 & -6.9 \\
\hline \multirow[t]{3}{*}{ T0901317 } & 481.3 & 89.9 & 91.5 & 78.2 & 77.9 & 81.5 & 80.9 & -59.1 \\
\hline & & \multicolumn{4}{|c|}{ AF-2 } & & & \\
\hline & MW & 2091 & 1NRL & $5 A 86$ & Energy & & & \\
\hline Pimecrolimus & 810.5 & 57.0 & 56.6 & 56.6 & -28.1 & & & \\
\hline Nelfinavir & 567.8 & 81.4 & 80.3 & 77.4 & -38.2 & & & \\
\hline Pazopanib & 437.5 & 74.2 & 71.4 & 75.9 & -61.7 & & & \\
\hline Ketoconazole (2R4S) & 531.4 & 78.0 & 78.9 & 71.5 & -40.5 & & & \\
\hline Ketoconazole (2S4R) & 531.4 & 80.5 & 85.6 & 82.2 & -41.9 & & & \\
\hline SR12813 & 504.5 & 62.3 & 63.1 & 62.1 & -25.4 & & & \\
\hline Rifampicin & 822.9 & 63.1 & 65.0 & 59.2 & -35.1 & & & \\
\hline T0901317 & 481.3 & 65.9 & 67.1 & 66.6 & -14.5 & & & \\
\hline
\end{tabular}

Docking scores of top-ranked poses of newly identified PXR inhibitors and other known PXR modulators. as well as redocked co-crystallised ligands SR12813 (PDB ID: 1NRL), T0901317 (2O9I) and hyperforin (1M13). For the LBP protonation at nitrogen atoms ND1 and NE2 of His407 were considered. Both enantiomers of ketoconazole (2R4S form and 2S4R form) were docked. Proteinligand complexes of top-ranked docking poses were energy-minimised and the interaction energy $(\mathrm{kcal} / \mathrm{mol})$ of the ligand with the protein was calculated using the Amber10:EHT force field. Abbreviations: MW, molecular weight 
Table 3 - Amino acid residues of the PXR LBP and AF-2 site interacting with the docked ligands.

\begin{tabular}{|c|c|c|c|c|c|c|c|c|}
\hline \multicolumn{6}{|c|}{ LBP } & \multicolumn{3}{|c|}{ AF-2 } \\
\hline PIM & NEL & PAZ & T0901317 & SR12813 & Hyperforin & PIM & NEL & PAZ \\
\hline $1 \mathrm{M} 13$ & 209I & 2091 & 209I & 1NRL & $1 \mathrm{M} 13$ & 209I & 2091 & $5 A 86$ \\
\hline & Leu206 & Leu206 & Leu206 & & & & & \\
\hline Leu209 & Leu209 & Leu209 & Leu209 & Leu209 & Leu209 & Lys252 & Lys252 & Lys252 \\
\hline Val211 & Lys210 & Lys210 & & & & Ile255 & Ile255 & Ile255 \\
\hline & Val211 & & & & & Ser256 & Ser256 & Ser256 \\
\hline & Ile236 & Ile236 & & & & Lys259 & Lys259 & Lys259 \\
\hline & Phe237 & Phe237 & & & & Phe264 & Phe264 & \\
\hline & Leu239 & Leu239 & & & & & Arg265 & \\
\hline Leu240 & Leu240 & Leu240 & Leu240 & & Leu240 & & Ile269 & \\
\hline Met243 & Met243 & Met243 & Met243 & Met243 & Met243 & Gln272 & Gln272 & \\
\hline & Ala244 & & & Ala244 & & Ile273 & Ile273 & Ile273 \\
\hline Met246 & Met246 & Met246 & & Met246 & & Leu276 & Leu276 & Leu276 \\
\hline Ser247 & Ser247 & Ser247 & Ser247 & Ser247 & Ser247 & Lys277 & Lys277 & Lys277 \\
\hline Phe281 & & & Phe281 & Phe281 & Phe281 & Leu424 & Leu424 & \\
\hline Gln285 & Gln285 & Gln285 & Gln285 & Gln285 & Gln285 & Glu427 & Glu427 & Glu427 \\
\hline Phe288 & Phe288 & Phe288 & Phe288 & Phe288 & Phe288 & Leu428 & Leu428 & Leu428 \\
\hline Trp299 & Trp299 & Trp299 & Trp299 & Trp299 & Trp299 & & & \\
\hline Tyr306 & Tyr306 & Tyr306 & Tyr306 & Tyr306 & & & & \\
\hline Met323 & Met323 & & Met323 & Met323 & Met323 & & & \\
\hline Leu324 & Leu324 & & Leu324 & & & & & \\
\hline His327 & His327 & & His327 & His327 & & & & \\
\hline His407 & His407 & & His407 & His407 & His407 & & & \\
\hline Thr408 & & & & & & & & \\
\hline Arg410 & & & Arg410 & & & & & \\
\hline Leu411 & Leu411 & & Leu411 & Leu411 & Leu411 & & & \\
\hline & & & Ile414 & & Ile414 & & & \\
\hline & Phe420 & & Phe420 & Phe420 & Phe420 & & & \\
\hline Met425 & Met425 & & & Met425 & & & & \\
\hline Phe429 & & & & Phe429 & & & & \\
\hline
\end{tabular}


For comparison, also interactions between co-crystallised ligands and PXR are listed. An interaction is defined as at least one heavy atom of the ligand and a neighbouring amino acid within $4 \AA$ distance to each other. Residues involved in hydrogen bonding or salt bridge formation are underlined

3.1.6 Novel antagonists differentially impair induction of PXR-regulated genes by rifampicin in primary human hepatocytes

Primary human hepatocytes were used to investigate whether the newly identified antagonists also interfere with the induction of hepatic gene expression mediated by PXR. Figure 12 demonstrates that the prototypical PXR agonist rifampicin induced the expression of a set of ADME genes (CYP2B6, CYP2C8, CYP3A4, AKR1B10, EPHX1, UGT1A3, ABCB1) and of the lipogenic enzyme FASN, which all have been described previously as PXR regulated genes [197-199]. Pimecrolimus and the known antagonist camptothecin demonstrated the most pronounced effects, antagonising the induction by rifampicin of four (camptothecin) or all (pimecrolimus) tested PXR-regulated genes. In contrast, pazopanib only impaired the rifampicindependent induction of AKR1B10, whereas nelfinavir was without significant effects. None of the chemical treatments significantly modulated the expression of RPLP0, which is not a PXR-regulated gene [198]. Interestingly, we observed induction of gene expression upon treatment with nelfinavir and pazopanib alone. 
Figure 12 - Novel PXR antagonists differentially affect the induction of PXRregulated genes by rifampicin in primary human hepatocytes.

CYP2B6

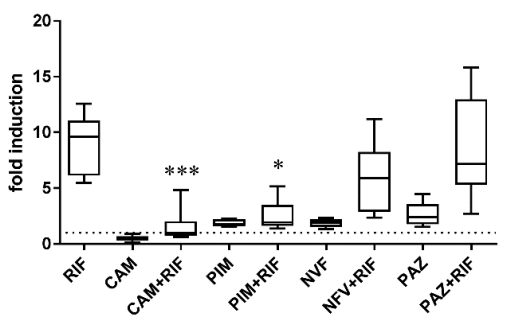

CYP3A4

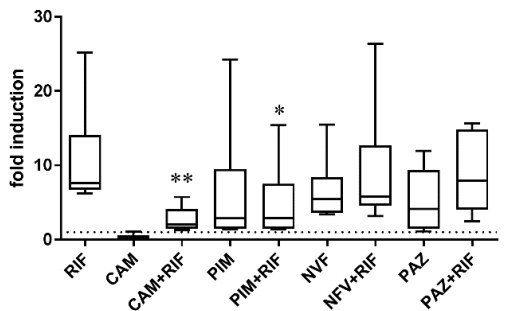

UGT1A3

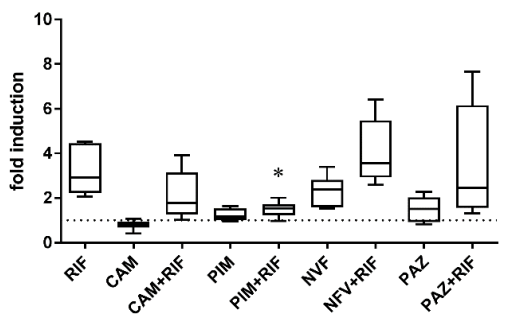

ABCB1

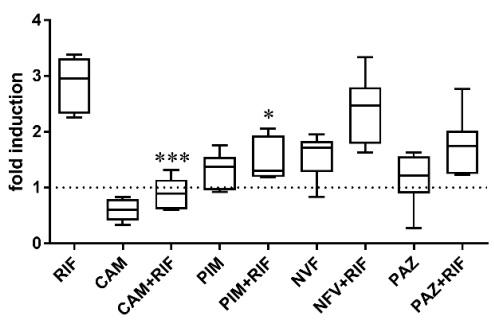

CYP2C8

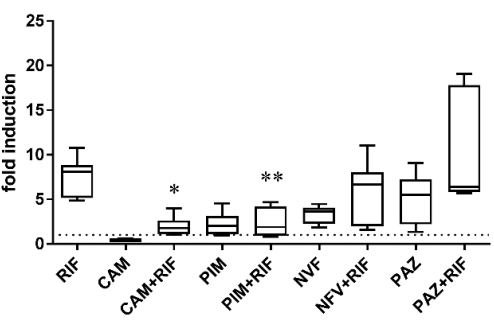

AKR1B10

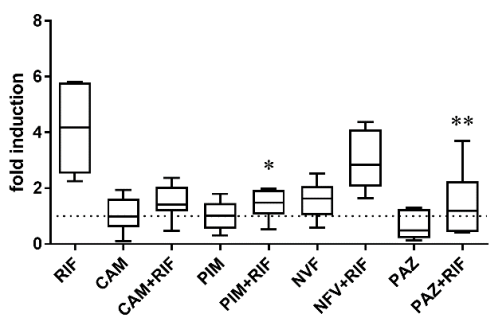

EPHX1
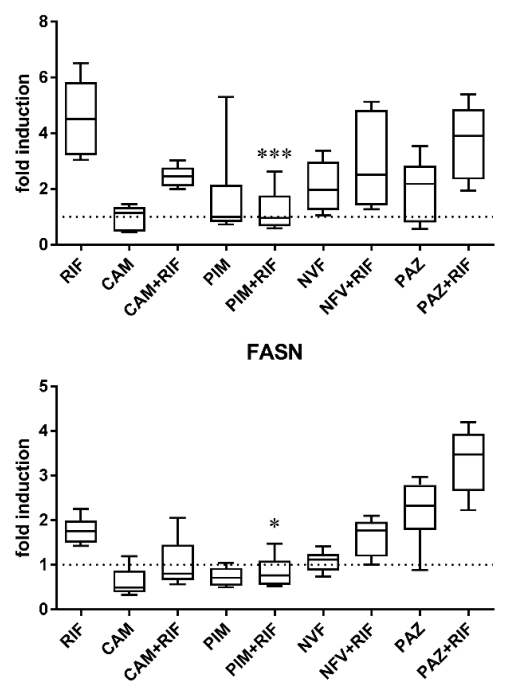

Cultured cells from 6 donors were each treated with $0.1 \%$ DMSO, $1 \mu \mathrm{M}$ camptothecin (CAM), $10 \mu \mathrm{M}$ pimecrolimus (PIM), nelfinavir (NFV) or pazopanib (PAZ), with or without $10 \mu \mathrm{M}$ rifampicin (RIF) for $24 \mathrm{~h}$. mRNA expression of the indicated genes was determined by TaqMan RT-qPCR and normalized to the expression of $18 \mathrm{~S}$ rRNA. The data are shown as fold induction by chemical treatment, as compared to the expression in cells treated with DMSO only, which was designated 1 , and are presented as box and whisker plots with boxes representing the $25^{\text {th }}$ to $75^{\text {th }}$ percentiles, medians indicated by horizontal lines and whiskers showing the minimum and maximum values. Significant differences to treatment with rifampicin only (exclusively for rifampicin co-treatments) were analysed by Friedman test with Dunn's multiple comparisons test. ${ }^{*}, p<0.05 ;{ }^{* *}, p<0.01 ;{ }^{* *}, p<0.001$. 


\subsection{Identification of CAR Inverse Agonists}

In order to identify novel CAR1 inverse agonists, all 784 compounds of the ENZO FDA-approved drug library V2 (10 $\mu \mathrm{M}$ each) were screened for reducing CAR1 constitutive activity. Figure 13 shows that 491 (62.6\%) of the tested compounds modulated the CAR1 activity of which $33(4.2 \%)$ revealed as potential CAR1 inverse agonists (Table 3). Also, treatment with $10 \mu \mathrm{M}$ of PK11195 (Figure 13 inset) substantially reduced the basal activity of CAR1, used here as a positive control for CAR inverse agonism. Assay performance thus showed a signal-to-background ratio of $\sim 2.5$ and $Z^{\prime}$ was 0.6 . Z' is usually considered acceptable if above 0.5 [177]. 
Table 4 - Primary Screening Hits and Hit Confirmation Results.

\begin{tabular}{|c|c|c|c|c|c|c|}
\hline Nr. & & Name & RA [\%] & \multicolumn{2}{|c|}{$\mathrm{IC}_{50}$} & Reference \\
\hline & & & & CAR1 & CAR2 & \\
\hline 1 & \multirow{13}{*}{$\begin{array}{l}0 \\
0 \\
\infty \\
0 \\
0 \\
0 \\
\infty \\
0 \\
0\end{array}$} & Gefitinib & 34.1 & 0.27 & 1.8 & \\
\hline 2 & & Miconazole & 33.3 & 10.8 & 1.4 & \\
\hline 3 & & Paclitaxel & 11.0 & 0.6 & 1.4 & \\
\hline 4 & & Pazopanib & 33.7 & 0.4 & 0.8 & \\
\hline 5 & & Sulconazole & 36.3 & 4.9 & 1.4 & \\
\hline 6 & & Clofarabine & 23.6 & n.c. & n.d. & \\
\hline 7 & & Cortisone & 35.1 & n.c. & n.d. & \\
\hline 8 & & Epirubicine & 13.5 & n.c. & n.d. & \\
\hline 9 & & Mechlorethamine & 22.8 & n.c. & n.d. & \\
\hline 10 & & 6-Thioguanine & 32.2 & n.c. & n.d. & \\
\hline 11 & & Sunitinib & 23.6 & n.c. & n.d. & \\
\hline 12 & & Sorafenib & 11.3 & n.c. & n.d. & \\
\hline 13 & & Tacrolimus & 29.0 & n.c. & n.d. & \\
\hline 14 & & Erlotinib & 27.4 & \multicolumn{2}{|c|}{ n.d. } & [200] \\
\hline 15 & \multirow{11}{*}{ 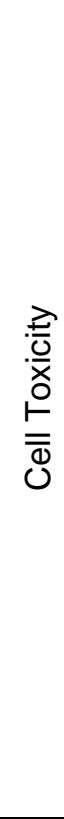 } & Auranofin & 2.8 & \multicolumn{2}{|c|}{ n.d. } & \\
\hline 16 & & Actinomycin D & 12.1 & \multicolumn{2}{|c|}{ n.d. } & \\
\hline 17 & & Bleomycin & 20.7 & \multicolumn{2}{|c|}{ n.d. } & \\
\hline 18 & & Butoconazole & 31.3 & \multicolumn{2}{|c|}{ n.d. } & \\
\hline 19 & & Cefuroxime & 18.9 & \multicolumn{2}{|c|}{ n.d. } & \\
\hline 20 & & Ciclopirox & 37.1 & \multicolumn{2}{|c|}{ n.d. } & \\
\hline 21 & & Cladribine & 26.4 & \multicolumn{2}{|c|}{ n.d. } & \\
\hline 22 & & Doxorubicin & 19.9 & \multicolumn{2}{|c|}{ n.d. } & \\
\hline 23 & & Floxuridine & 34.4 & \multicolumn{2}{|c|}{ n.d. } & \\
\hline 24 & & Milnacipran & 22.8 & \multicolumn{2}{|c|}{ n.d. } & \\
\hline 25 & & Mitoxantrone & 23.6 & \multicolumn{2}{|c|}{ n.d. } & \\
\hline 26 & $\begin{array}{l}\overline{7} \\
\frac{\mathbb{0}}{0}\end{array}$ & Adefovir & 17.0 & \multicolumn{2}{|c|}{ n.d. } & [123] \\
\hline 27 & 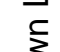 & Bortezomib & 14.0 & \multicolumn{2}{|c|}{ n.d. } & [123] \\
\hline 28 & $\frac{\Sigma}{\Sigma}$ & Carvedilol & 15.0 & \multicolumn{2}{|c|}{ n.d. } & [123] \\
\hline
\end{tabular}




\begin{tabular}{|c|c|c|c|c|}
\hline 29 & \multirow{4}{*}{30} \\
\cline { 1 - 4 } 31 & Clotrimazole & 23.8 & n.d. & {$[100,118]$} \\
\cline { 3 - 5 } 32 & Daunorubicin & 12.0 & n.d. & {$[123]$} \\
\cline { 2 - 5 } 32 & Digoxin & 38.1 & n.d. & {$[123]$} \\
\cline { 2 - 5 } 33 & Hexachlorophene & 36.1 & n.d. & {$[138]$} \\
\cline { 2 - 5 } & Methotrexate & 33.2 & n.d. & {$[201,202]$} \\
\hline
\end{tabular}

Residual activity (RA) describes the normalised reporter activity of compound-treated HEK293T cells compared to DMSO-treated cells. Compounds 1-13 were re-purchased and tested in a dose-response manner for CAR1 and CAR2 inhibition. Compound 14 was excluded due to availability issues Compounds 15-25 and 26-33 were not further considered either due to toxicity issues or as these have been previously described as CAR 1 inverse agonists. $I_{50}$ values were determined using a sigmoidal antagonist model implemented in GraphPad Prism 5. Abbreviations: n.c., not confirmed; n.d., not determined.

Figure 13 - Screening of a chemical library of 784 compounds for CAR1 inhibition.

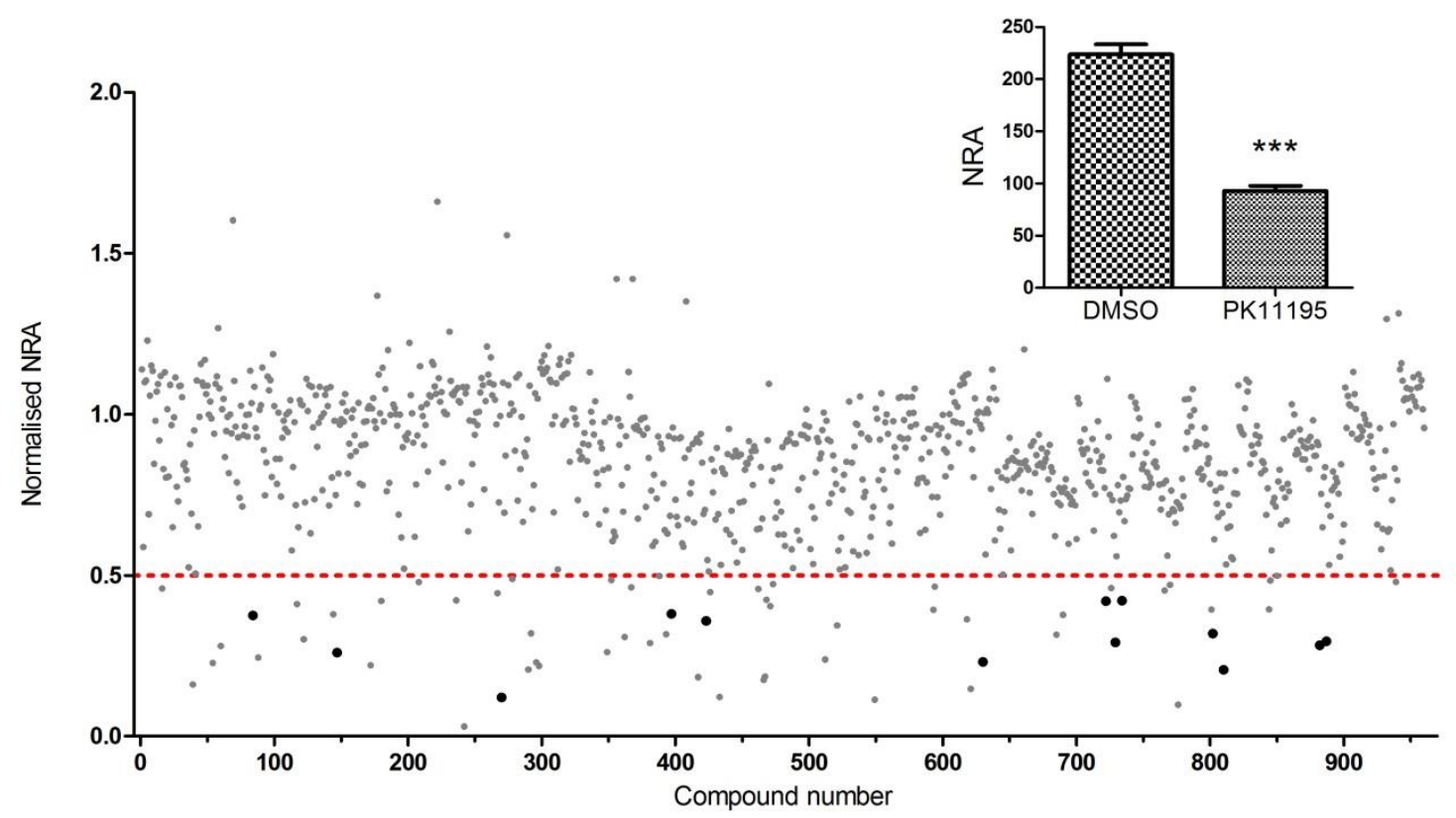

HTS application over HEK293T, which were co-transfected with CYP3A4 enhancer/promoter firefly luciferase reporter gene construct, expression plasmids encoding human CAR1 and RXRa and Renilla luciferase plasmid pRL-TK-Renilla for normalisation. Cells were treated for $24 \mathrm{~h}$ with PK11195 $(10 \mu \mathrm{M})$, DMSO control $(0.1 \%)$ or $10 \mu \mathrm{M}$ of the respective library compounds. Points show normalised reporter activities of cells treated with individual mixtures of the compounds relative to the cells treated with DMSO, which was set as 1 . The red dotted line represents the $50 \%$ activity threshold, with candidate inverse agonists below highlighted as black dots. Inset: columns show means $\pm \mathrm{SEM}(\mathrm{N}=3)$ of normalised reporter activities (NRA) of the indicated control treatments with vehicle DMSO or the standard inverse agonist PK11195 $(10 \mu \mathrm{M})$ present in all the screening plates. Statistical significant differences between treatments versus DMSO control, as analysed by one-way analysis of variance with Dunnett's post-test, are indicated by asterisks $\left({ }^{* * *}, p<0.001\right)$.

By excluding compounds that modulated Renilla activity or showed some degree of toxicity against HEK293T cells from further investigations, due to structural similarity 
erlotinib can active CAR by inducing its nuclear translocation though fails on transactivation cell-based assays [200], 13 of 33 compounds remained. Subsequently conducted dose-response experiments confirmed five of these compounds as real CAR1 inverse agonists: gefitinib $\left(\mathrm{IC}_{50}=0.27 \mu \mathrm{M}\right)$, miconazole $(10.8 \mu \mathrm{M})$, paclitaxel $(0.62 \mu \mathrm{M})$, pazopanib $(0.42 \mu \mathrm{M})$ and sulconazole $(4.9 \mu \mathrm{M})$ (Figure 14, Table 4). For PK11195 the $\mathrm{IC}_{50}$ was determined to be $1.4 \mu \mathrm{M}$. 
Figure 14 - CAR1 inverse agonist hit confirmation and selectivity towards CAR2.

A

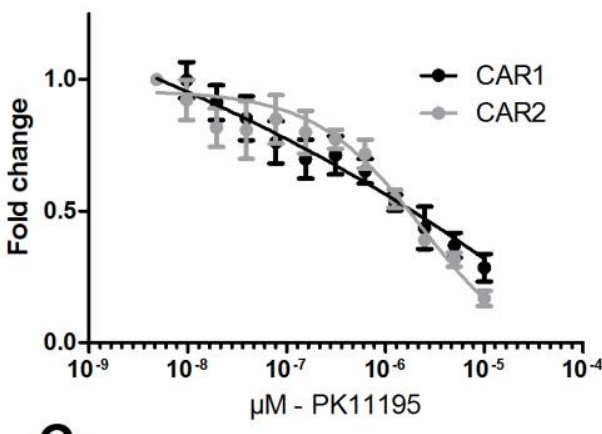

C

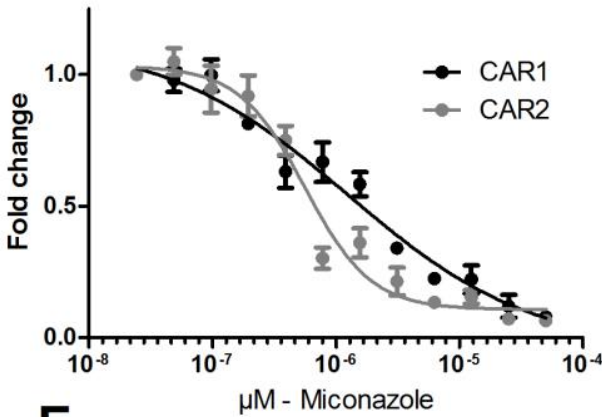

E

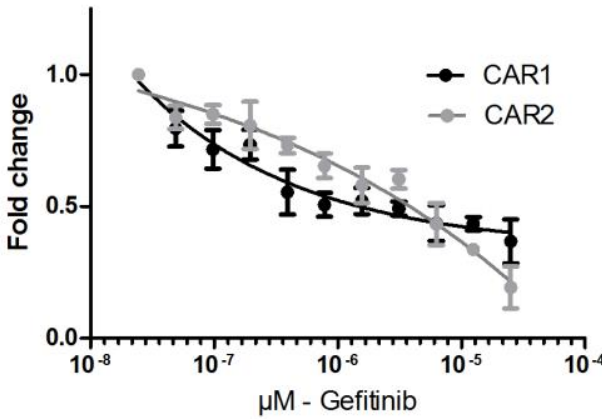

B

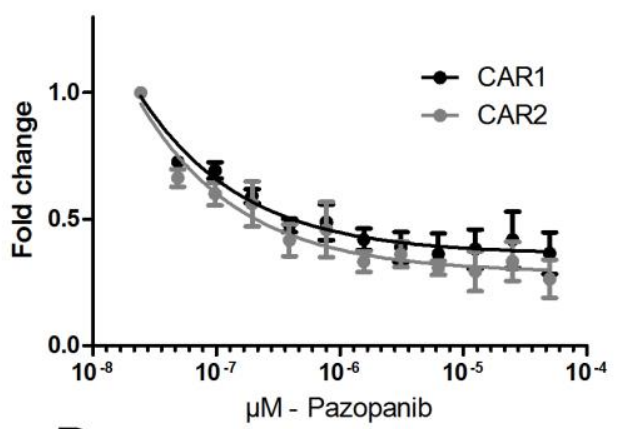

D
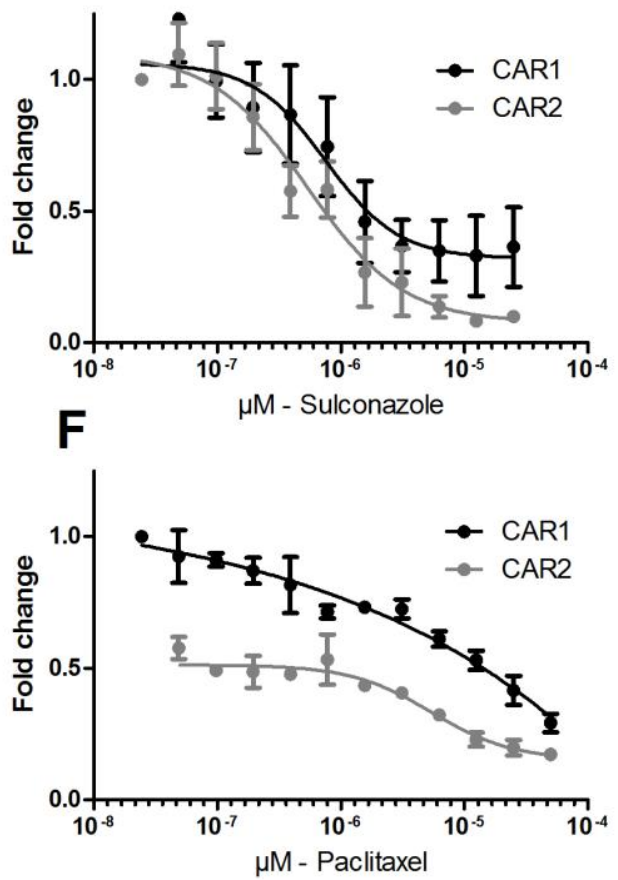

Dual CARsv1 (CAR1) and CARsv3 (CAR2) inverse agonists identified on the primary screening are able to reduce promoter activity. HEK293T cells were transfected with pGL4-CYP3A4(-7830/A7208$364)$ and pcDhCAR1, pcDhCAR2 or empty pCDNA3.1 $1^{(+)}$as described before and treated with increasing concentrations $(0.01-10 \mu \mathrm{M}$ for $\mathrm{A}$ and 0.2-50 $\mu \mathrm{M} \mathrm{B}-\mathrm{F})$ of PK11195 (A) pazopanib (B), miconazole $(C)$, sulconazole $(D)$, gefitinib $(E)$, paclitaxel $(F)$ or DMSO $(0.1 \%)$ for 24 hours. Firefly and Renilla luciferase activities were measured using DualGlo Luciferase kit after treatment. Fold change stands for the normalised Relative Luciferase Units (ratio between Firefly and Renilla activities) of treated transfected cells with the NR expressing plasmid towards the mock cell line (transfected with the empty plasmid). Points represent mean of average ( $\pm S E M)$ of at least 3 experiments.

None of the newly identified CAR1 inverse agonists emerged as toxic at low concentrations. While miconazole and sulconazole showed toxicity on HEK293T cells around $50 \mu \mathrm{M}$, the other three compounds were not toxic at all concentrations (Figure $15)$. 
Figure 15 - Cell viability of CAR inverse agonists

A

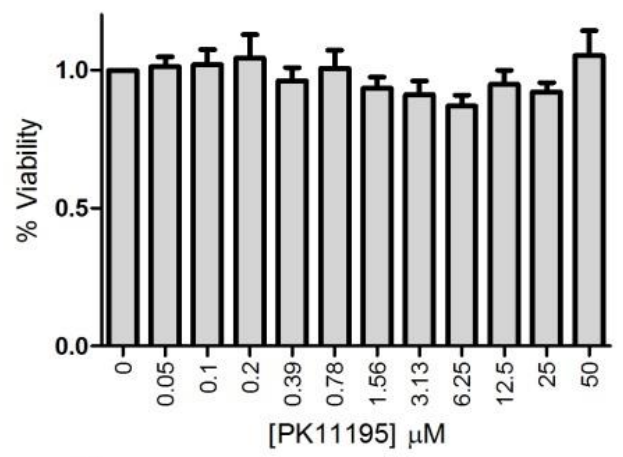

C

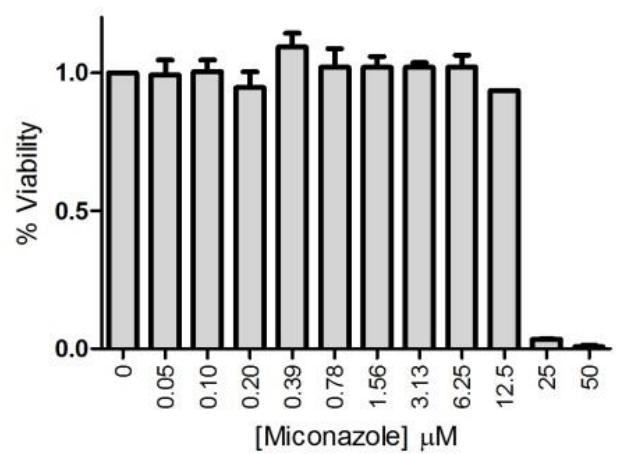

E

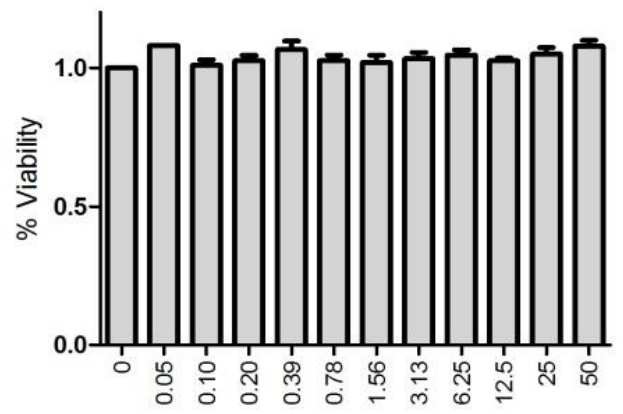

[Gefitinib] $\mu \mathrm{M}$
B

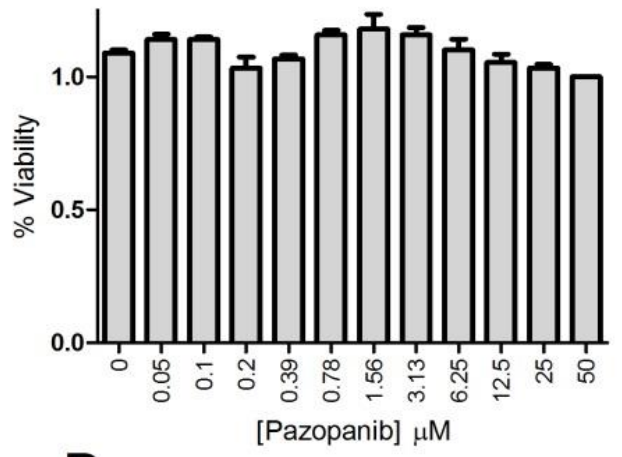

D

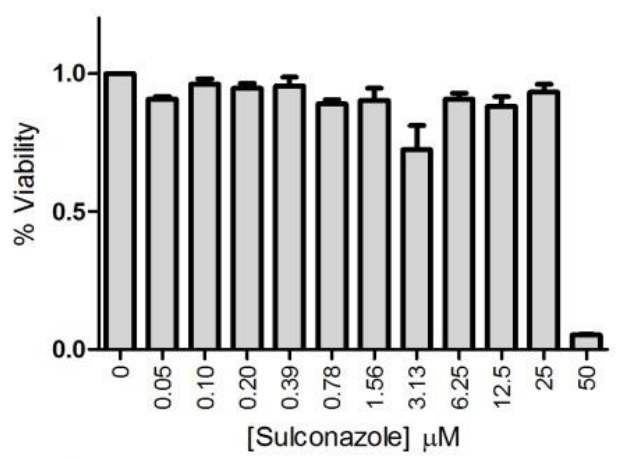

$\mathbf{F}$

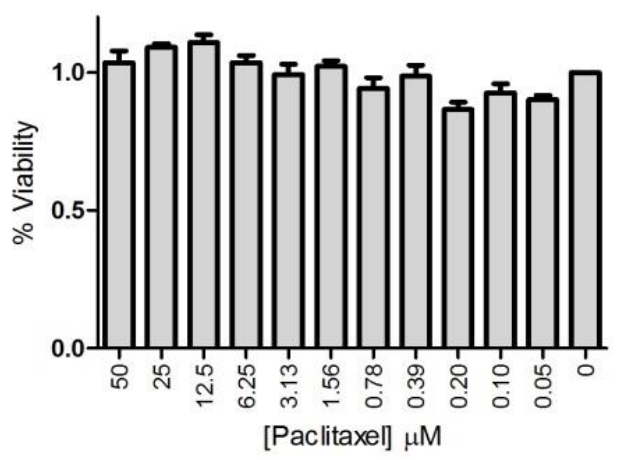

(A-F) HEK293T cells were seeded and treated next day with increasing concentrations of PK11195 $(A)$, pazopanib $(B)$, miconazole $(C)$, sulconazole $(D)$, gefitinib $(E)$, paclitaxel $(F)$ or $0.1 \%$ DMSO for additional $48 \mathrm{~h}$. Columns represent means \pm SEM $(N \geq 3)$.

\subsubsection{CAR Isoform and PXR Selectivity}

In order to assess modulation of other NRs by the identified CAR1 inverse agonists, we evaluated their receptor silencing potential against another constitutively active CAR splice variant (CAR2) using a reporter gene assay in HEK293T cells. All 
compounds revealed as potent inverse agonists of CAR2 in a dose-dependent manner with $\mathrm{IC}_{50}$ values ranging from $0.8 \mu \mathrm{M}$ to $1.4 \mu \mathrm{M}$ (Figure 14, Table 4). For PK11195 the $\mathrm{IC}_{50}$ was determined to be $13 \mu \mathrm{M}$.

Also, all compounds were tested for PXR activation in HEK293T and HepG2 cells using a reporter gene assay. In HEK293T cells, miconazole and sulconazole revealed potent PXR activation in the same dose range of the respective CAR $I C_{50}$ values (Figure 3A). Paclitaxel-induced PXR activation at the low micromolar range, which is in agreement with literature data [135]. Only pazopanib and gefitinib showed no PXR induction at any tested concentration (Figure 16).

Figure 16 - miconazole, sulconazole and paclitaxel effectively activate the reporter activity of PXR, but not gefitinib or pazopanib.

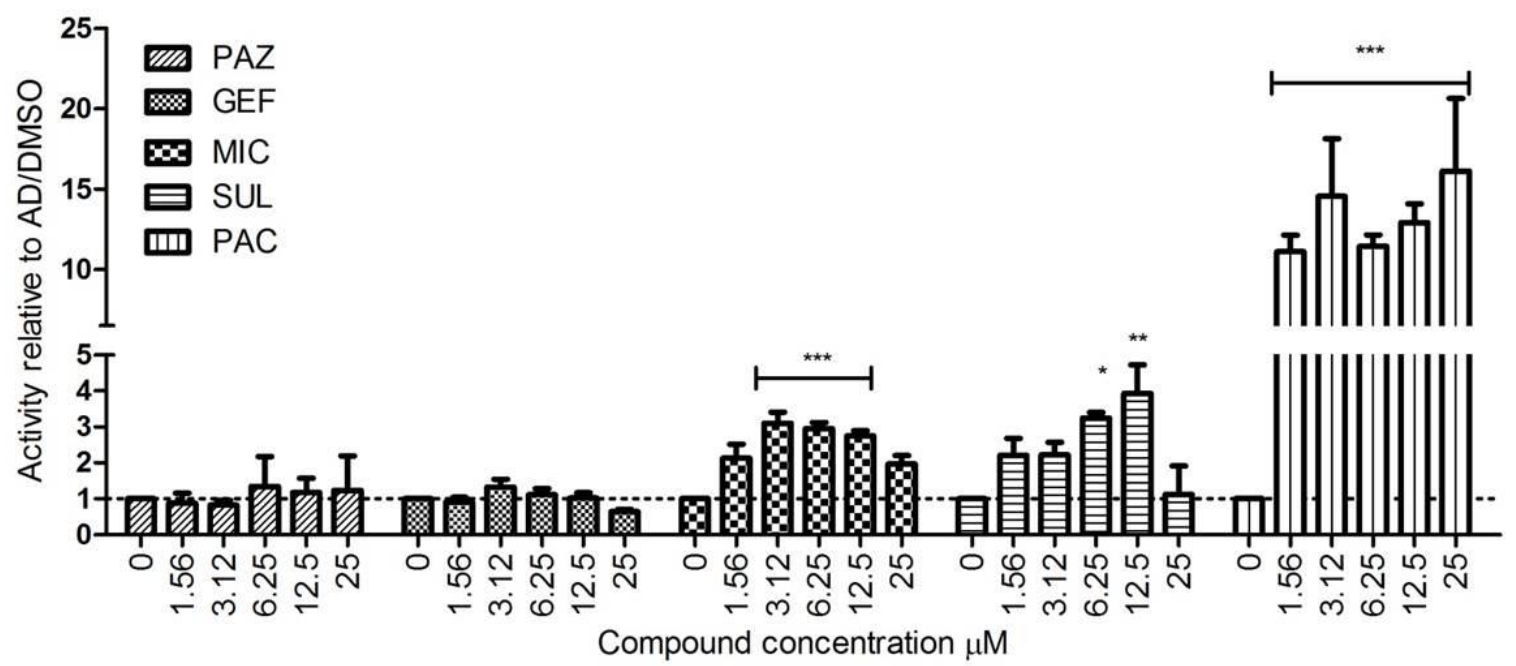

PXR modulation by CAR1 screening hits evaluated by CYP3A4 promoter activity on transfected HepG2 cells. HepG2 cells were transfected with pGL4-CYP3A4(-7830/D7208-364) and pcDhPXR or pCDNA3(-). Cells were treated next morning with DMSO $(0.1 \%)$ or increasing concentrations of pazopanib (PAZ), gefitinib (GEF), miconazole (MIC), sulconazole (SUL) and paclitaxel (PAC) for additional 24 hours. Firefly and Renilla luciferase activities were measured using DualGlo Luciferase kit after treatment. Columns show means \pm SEM $(N \geq 3)$ of normalised luciferase activity of the cotransfected pcDhPXR firefly luciferase reporter gene plasmid, relative to the activity of cells transfected with pCDNA3(-) and treated with $0.1 \%$ DMSO only. Statistical significant differences between treatments versus DMSO control, as analysed by two-way ANOVA with Bonferroni's post-test are indicated by asterisks $\left({ }^{*}, p<0.05 ;{ }^{* *}, p<0.01 ;{ }^{* \star *}, p<0.001\right)$.

In addition, a TR-FRET assay was employed to study CAR inverse agonist binding to the PXR ligand-binding pocket. The ratio between the PXR-fluormone complex and free PXR was normalised towards the controls rifampicin (RIF, $50 \mu \mathrm{M})$ and vehicle (DMSO, $1 \%$ ) after $6 \mathrm{~h}$ treatment (Figure 17A). CAR inverse agonists were evaluated at $25 \mu \mathrm{M}$ after $6 \mathrm{~h}$ incubation with the PXR-fluormone complex. Compared to known 
PXR agonist rifampicin, sulconazole, miconazole, paclitaxel and pazopanib showed significantly weaker binding to the PXR LBD, while gefitinib did not bind at all (Figure 17B).

Figure 17 - Binding of CAR inverse agonists to PXR ligand binding pocket.

A

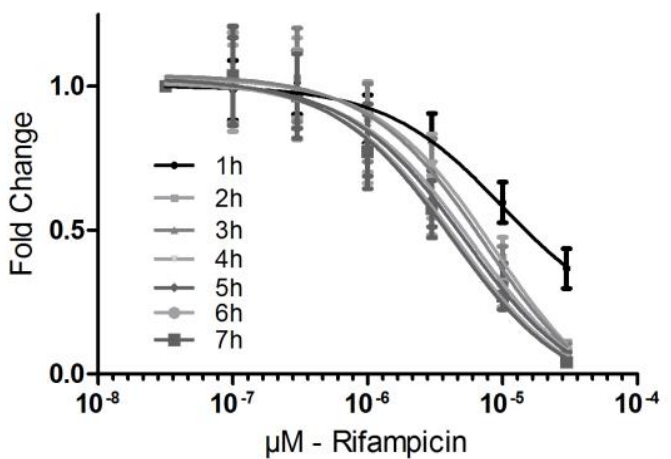

B

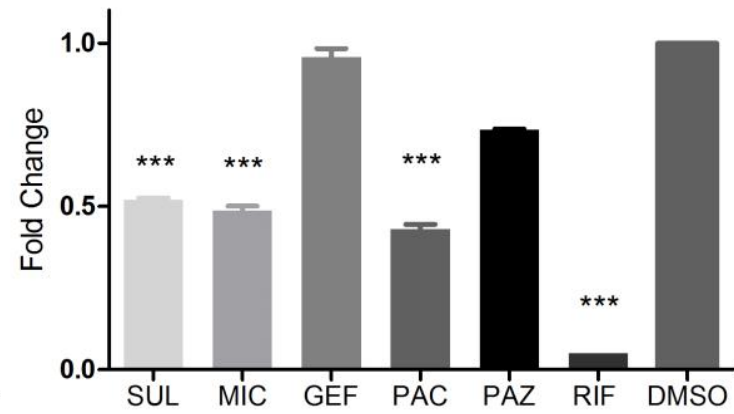

TR-FRET assay was employed to study the competition of the CAR inverse agonists to the PXR ligand binding pocket, by displacing a fluormone substrate. The ratio between complex PXRfluormone and free PXR was measured by emitted fluorescence at $515 \mathrm{~nm}$ and $490 \mathrm{~nm}$, upon $340 \mathrm{~nm}$ excitation, respectively. A) Dose-response of rifampicin $(0.1-50 \mu \mathrm{M})$ along the time B) Emission ratios were normalised towards the controls Rifampicin $(50 \mu \mathrm{M})$ and vehicle (DMSO, $1 \%$ ). Compounds: pazopanib (PAZ), gefitinib (GEF), miconazole (MIC), sulconazole (SUL) and paclitaxel (PAC), were used at $25 \mu \mathrm{M}$ and evaluated after $6 \mathrm{~h}$ incubation with the PXR-fluormone complex and the displacement measured as described. Significant differences in respective treatments with DMSO (asterisks) were analysed by multiple paired t-tests. ${ }^{* \star *}, p<0.001$.

\subsubsection{Ligand-Binding Domain Assembly and Co-activator Recruitment}

The nuclear receptor ligand-binding domain assembly assay likewise identifies agonists as well as antagonists binding to the LBP (Pissios et al. 2000). Thus, we analysed induction of the assembly of CAR1 ligand-binding domain by the five molecules. Figure 18A shows that none of the compounds induced the assembly of CAR1 LBD in HEK293T cells, while agonist CITCO and the inverse agonist PK11195 clearly induced the assembly. 
Figure 18 - Receptor Assembly and Coactivator Recruitment.
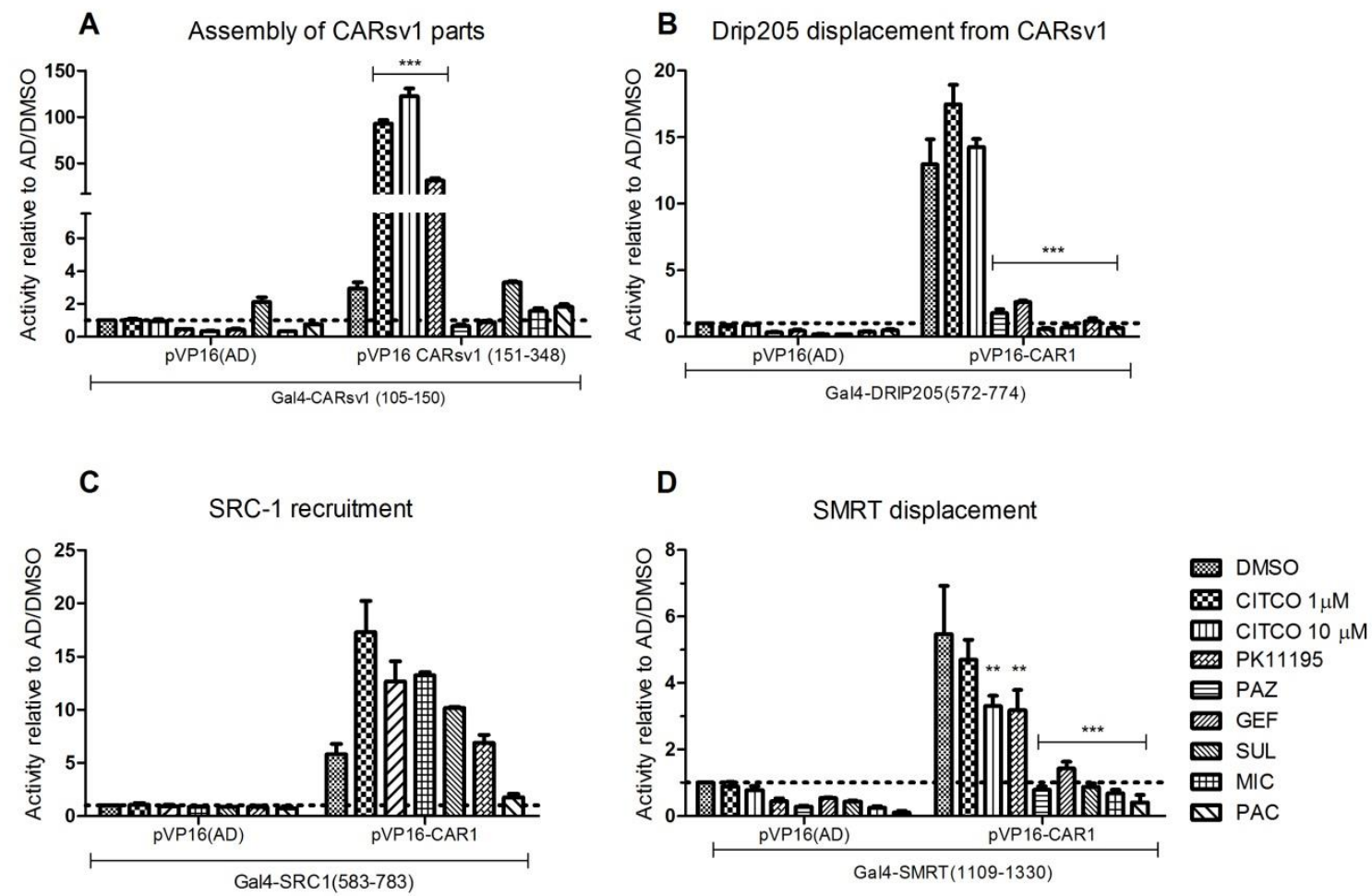

Inverse agonists were able to displace constitutive DRIP205 interaction, decrease interaction with corepressor, but not assembly receptor individual parts. HEK293T cells were transfected with empty expression vector pVP16-AD or plasmids encoding pVP16-CAR1(105-438) (A and C) or VP16DBD/hCAR-LBD(105-150) (for C). Additional plasmids encoding NRID or CAR counterpart were cotransfected according to the assay employed: A) GAL4-DBD-CAR1(151-438) for assembly assay of CAR parts; B) pM-DRIP205(527-774 displacement from CAR1; C) GAL4-DBD/SRC-1(583-783) as a co-activator interaction test (all compounds within this test were cotreated with $10 \mu \mathrm{M}$ of CITCO) and D) pM-SMRT (1109-1330) for corepressors interaction. Transfected cells were treated with pazopanib (PAZ), gefitinib (GEF), miconazole (MIC), sulconazole (SUL) or paclitaxel (PAC) for 24 hours $(10 \mu \mathrm{M}$ each). Columns show means \pm SEM $(\mathrm{N} \geq 3)$ of normalised luciferase activity of the co-transfected pGL3-G5 Firefly luciferase reporter gene plasmid, relative to the activity of cells transfected with pVP16-AD and treated with $0.1 \%$ DMSO only. Statistical significant differences between treatments versus DMSO control, as analysed by two-way ANOVA with Bonferroni's post-test are indicated by asterisks $\left({ }^{*}, \mathrm{p}<0.05 ;{ }^{* *}, \mathrm{p}<0.01 ;{ }^{* * *}, \mathrm{p}<0.001\right)$.

In HEK293T cells the co-activator DRIP205 constitutively interacted with CAR1 (Figure 18B) and the standard agonist CITCO did not significantly increase this interaction. All five tested compounds displaced the DRIP205 NRID. Using the same cell line, all inverse agonists also reduced the interaction of SRC1 with CAR1 (Figure 18C), even when co-treated with CITCO at different concentrations (Figure 19). Despite impairment of co-activator binding, none of the compounds induced recruitment of the co-repressor SMRT (Figure 18D). 
Figure 19 - Inverse agonists block the SRC1 recruitment by CAR1.

SRC-1 recruitment

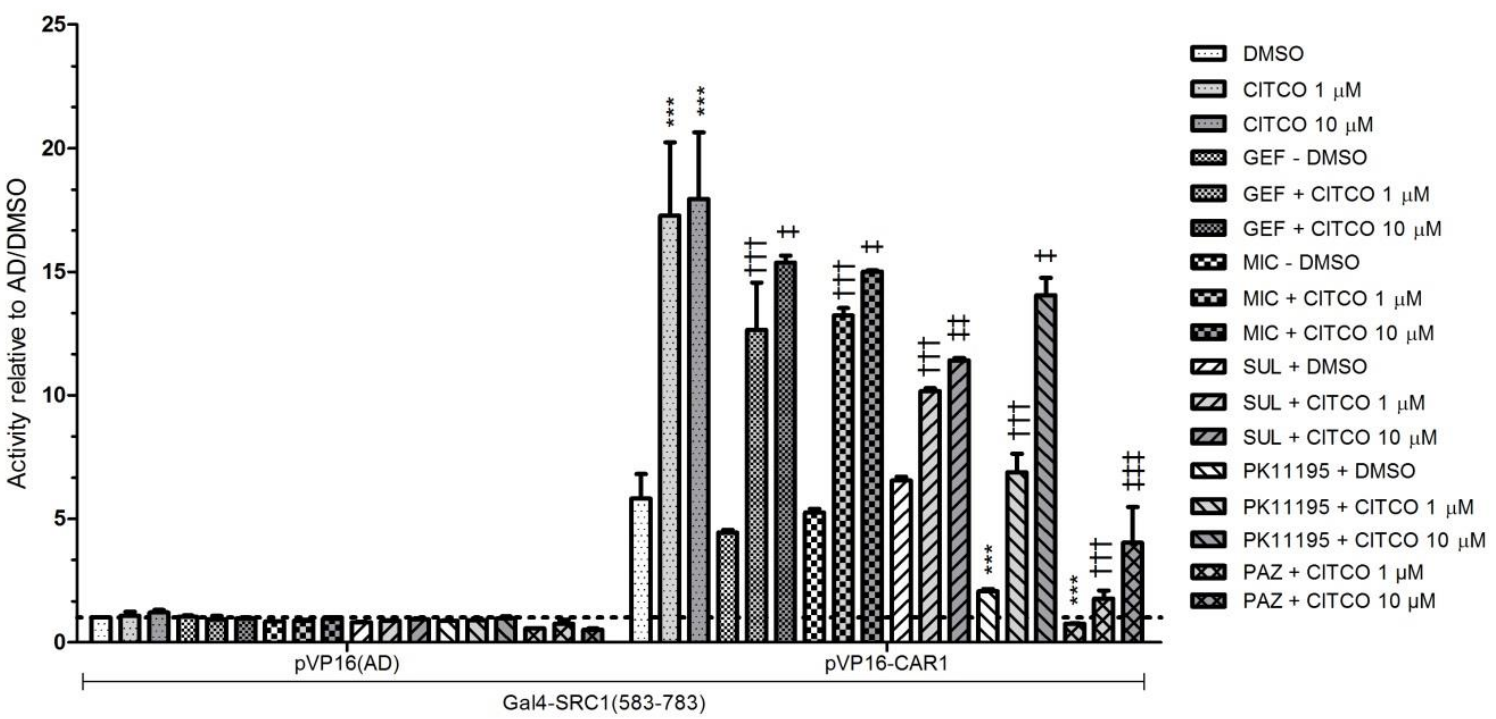

Interaction between SRC1 and CAR1. HEK293T cells were cotransfected with a plasmid encoding GAL4-DBD/SRC-1(583-783) fusion protein and plasmids encoding the indicated VP16-AD/CAR-LBD fusion proteins or empty expression vector pVP16-AD $(-)$ and treated with mentioned compound combination for $24 \mathrm{~h}$. Following compounds: pazopanib (PAZ), gefitinib (GEF), miconazole (MIC), sulconazole (SUL) or paclitaxel (PAC) were added in a concentration of $10 \mu \mathrm{M}$ and tested in combination with CITCO $(1 \mu \mathrm{M}$ or $10 \mu \mathrm{M})$ or vehicle (DMSO). Columns show means \pm SEM $(\mathrm{N} \geq 3)$ of normalised luciferase activity of the co-transfected pGL3-G5 Firefly luciferase reporter gene plasmid, relative to the activity of cells transfected with pVP16-AD and treated with $0.1 \%$ DMSO only. Significant differences in respective treatments with DMSO (asterisks), with CITCO $1 \mu \mathrm{M}$ (daggers) or with CITCO $10 \mu \mathrm{M}$ (double-crossed dagger $\ddagger$ ) were analysed by two-way ANOVA with Bonferroni's multiple comparison tests $\left(\dagger, \ddagger: p<0.05 ; \dagger \dagger, ~ \ddagger \ddagger: p<0.01 ;{ }^{* * *}, \dagger \dagger \dagger, ~ \ddagger \ddagger \ddagger: ~ p<0.001\right)$

\subsubsection{Inverse agonist interaction with AF-2 site}

In order to analyse protein-ligand interactions of the identified CAR1 inverse agonists, the compounds were docked into the AF-2 region of the CAR1 X-ray crystal structure. Compounds mainly interact with the AF-2 via van der Waals interactions. Except for gefitinib (Figure 20A) and paclitaxel (Figure 20E), all other compounds share a charged hydrogen bond with the charge clamp residue Glu345. In addition, pazopanib forms a cation- $\pi$ interaction with Lys177 (Figure 20B). Miconazole and sulconazole reveal almost identical binding modes of the dichloro phenyl imidazole groups (Figure 20C-D). The interaction pattern with AF-2 residues varies between different compounds (Table 6). The only compound not fitting well into the AF-2 
pocket is paclitaxel, of which a large fraction projects into the solvent without any contact to the receptor.

Figure 20 - Predicted binding modes of CAR inverse agonists on the AF-2 region.

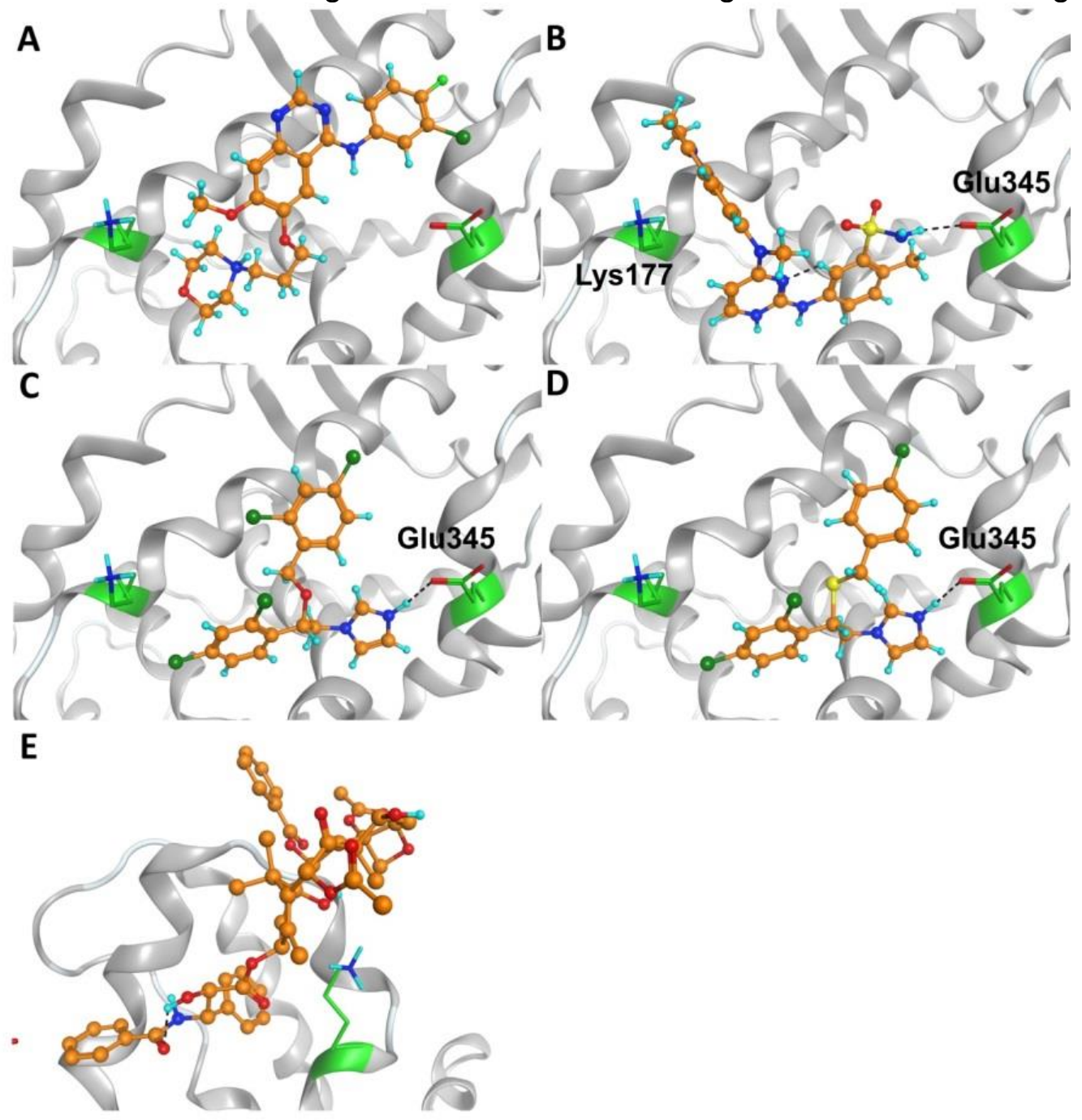

Top-ranked docking poses of A) gefitinib B) pazopanib, C) miconazole, D) sulconazole and E) paclitaxel generated with docking program GOLD and scoring function ChemPLP. Protein backbone is shown as a grey ribbon. Ligand carbon atoms are coloured orange, selected residues of the AF-2 site are shown with carbon atoms in green. Hydrogen bonds are indicated by dotted lines. 
Table 5 - Docking scores of the top-ranked poses for the newly identified CAR antagonists

\begin{tabular}{llllll}
\hline Compound & \#HA & MW & ChemPLP & LE & Interactions \\
\hline Miconazole & 25 & 418 & 60.8 & 2.42 & Hydrogen bond Glu345 \\
Paclitaxel & 62 & 854 & 77.9 & 1.25 & \\
Pazopanib & 31 & 439 & 57.5 & 1.85 & Hydrogen bond with Glu345/Lys177 \\
Sulconazole & 24 & 400 & 61.3 & 2.55 & Hydrogen bond Glu345 \\
Gefitinib & 31 & 447 & 56.6 & 1.83 & \\
\hline
\end{tabular}

Overview of the different compounds found on the screening docked on the AF-2 region in order to propose a binding mode on an alternative binding site. Abbreviations: HA, the number of heavy atoms; LE, Ligand efficiency (ratio between the docking score and number of heavy atoms); MW, molecular weight.

Table 6 - List of amino acid residues of CAR1 - AF2 region interacting with docked compounds.

\begin{tabular}{lllll} 
Miconazole & Sulconazole & Gefitinib & Pazopanib & Paclitaxel \\
\hline Leu170 & Leu170 & Leu170 & & \\
Ile173 & Ile173 & Ile173 & Ile173 & Ile173 \\
Lys177 & Lys177 & Lys177 & Lys177 & Lys177 \\
& & Phe182 & Phe182 & Phe182 \\
Ile187 & Ile187 & Ile187 & Ile187 & Ile187 \\
Gln190 & Gln190 & Gln190 & Gln190 & Gln190 \\
Ile191 & Ile191 & Ile191 & Ile191 & Ile191 \\
Leu194 & Leu194 & Leu194 & Leu194 & Leu194 \\
Lys193 & Lys193 & & Lys193 & Lys193 \\
& & Pro341 & & \\
Leu342 & Leu342 & Leu342 & Leu342 & \\
Glu345 & Glu345 & Glu345 & Glu345 & Glu345 \\
Ile346 & Ile346 & & Ile346 & Ile346
\end{tabular}

An interaction is defined as at least one heavy atom of the ligand and a neighbouring amino acid within $4 \AA$ distance to each other. Identification of ligand-interacting residues was made within MOE. 
4 DISCUSSION 


\subsection{Identification of novel PXR antagonists}

Using a comprehensive set of cell-based and biochemical assays, we have identified the drugs pimecrolimus, nelfinavir and pazopanib as antagonists of rifampicinactivated $\mathrm{PXR}$ with $\mathrm{IC}_{50}$ values in the low micromolar range. The previously reported PXR antagonists ketoconazole, fluconazole, metformin, leflunomide and itraconazole did not demonstrate inhibitory potential in our primary screening. For the first three compounds, this is likely due to the $10 \mu \mathrm{M}$ concentration used for primary screening, since these have been reported to be weak antagonists at this concentration (ketoconazole), or potently inhibit PXR at $25 \mu \mathrm{M}$ (ketoconazole, fluconazole) or $>500 \mu \mathrm{M}$ (metformin), respectively [147,149,203]. Published data regarding antagonism by leflunomide and itraconazole are contradictory. While in one study both compounds have been reported as antagonists [138], a more recent investigation demonstrated PXR agonism of leflunomide [134]. Itraconazole has been described not to bind to the PXR LBD but rather, as observed in this study, to further stimulate receptor activity pre-activated by rifampicin [204].

In accordance with previously described PXR antagonists, ketoconazole, sulforaphane, coumestrol, camptothecin and FLB-12 [136,137,145,149] all novel antagonists displaced co-activator SRC-1. In addition, the three novel antagonists and camptothecin also decreased the interaction with co-repressor SMRT which so far has been only observed for ketoconazole [146,149]. When tested without rifampicin pre-activation, nelfinavir induced PXR activation which is in agreement with a previous study (Svärd et al 2010). The same effect has been also described for ketoconazole that alone slightly induced PXR but inhibited the receptor when pretreated with the agonists corticosterone or rifampicin, respectively (Takeshita et al 2002, Huang et al 2007).

The novel antagonists show differential PXR interaction profiles. There is strong experimental evidence that nelfinavir binds exclusively to the LBP, as indicated by the positive LBD assembly as well as results obtained by the limited proteolytic digestion and TR-FRET assays, despite the weaker signal when compared to rifampicin. Also, the inability of nelfinavir to inhibit LBP-filled PXR mutants strongly suggests its binding to the LBP. In contrast, pimecrolimus seems to be capable of binding both into the LBP and to an alternative site on the LBD, as previously described for coumestrol [137]. While the observed LBD assembly and the protection 
of the proteolytic fragments from limited proteolytic digestion suggest compound binding to the LBP, the inhibition of the LBP-filled PXR mutants suggests an alternative binding site. Pazopanib, in turn, is suggested to bind exclusively to a site outside of the LBP, in that resembling camptothecin, ketoconazole and FLB-12, which were all shown not to compete for agonist binding to PXR in competition ligand binding assays [133,145], and FLB-12 additionally was shown to inhibit the constitutive activity of a LBP-filled PXR mutant [133,145]. Pazopanib displacement in TR-FRET assay is quite low, in particular compared to rifampicin, and the signal quenching has already been discussed as a source of artefacts for this type of assay [205].

In silico molecular docking revealed favourable binding of nelfinavir and pazopanib to the LBP and all three compounds to the AF-2. Results for pimecrolimus are difficult to interpret as the PXR LBP is known to adapt to bound ligands and all available PXR X-ray crystal structures, with reasonable resolution and acceptable stereochemical quality, have been co-crystallised with significantly smaller compounds. However, a low resolution crystal structure binding rifampicin has been published, which was not employed in the docking studies due to the missing residues in the LBP region [206]. Also, it cannot be excluded that the compounds bind to other areas of the LBD and allosterically prevent coactivator and co-repressor binding as shown e.g. for androgen receptor [207]. So far, there is only experimental evidence for ketoconazole binding to the AF-2 site. PXR single (GIn272His) or double mutant (Thr248Glu \& Lys277GIn) has been shown to prevent ketoconazole antagonism [203].

Gene expression studies using primary hepatocytes revealed that only pimecrolimus effectively down-regulated all tested PXR-dependent genes. As in vitro and in vivo studies revealed the metabolism of pimecrolimus to involve multiple oxidative $\mathrm{O}$ demethylations and hydroxylations resulting in a complex mixture of metabolites [208], it is unclear whether the inhibition is based on the unchanged drug or a metabolite. Also, it cannot be excluded that simultaneous binding of pimecrolimus to the LBP and the AF-2 site is responsible for the effective down-regulation.

Compared to pimecrolimus, only three nelfinavir metabolites have been identified so far of which two have been found in plasma [209]. Co-administration of nelfinavir and rifampicin has been shown to significantly decrease plasma concentrations of nelfinavir [210], which may explain the observed lack of PXR target gene down- 
regulation. The increase in target gene expression upon administration of nelfinavir alone is in agreement with our reporter gene assay results.

So far, no study on drug-drug interactions between rifampicin and pazopanib has been conducted. However, publicly available information from FDA and EMA report that the concomitant use of a potent CYP3A4 inducer such as rifampicin may decrease pazopanib concentrations. In contrast to the reporter gene assays, pazopanib alone induced expression of some PXR-modulated genes. A human metabolism and disposition study of pazopanib revealed the presence of only two metabolites in plasma at low concentrations and a primary elimination of the unchanged drug from the body [211]. Therefore it is unlikely that pazopanib metabolites are responsible for the observed effect. It cannot be excluded that pazopanib interferes with other pathways resulting in up-regulation of the investigated genes. To our best knowledge so far no direct involvement of pazopanib targets VEGFR, PDGFRB or c-Kit in the regulation of the investigated genes has been reported.

Our study not only provides further evidence that besides PXR induction also receptor inhibition by approved drugs may result in unwanted drug-drug interactions but also confirms the existence of several ligand-binding sites on the LBD that allow different ligand interaction profiles. In addition, the results of our work may support the development of potent PXR inhibitors that could be applied for improving therapeutic efficacy by preventing drug-drug interactions or as a treatment option for cancer therapy (Zhuo et al 2014; Wang et al 2011). 


\subsection{Identification of novel CAR inverse agonists}

Multiple drug treatment can lead drug-induced hepatotoxicity mediated by CAR [108], as well, drug resistance. Therefore, knowledge about drugs interfering with CAR activation as well as the mechanism is important for drug-therapy. Moreover, target CAR activation using antagonists can be useful to reduce the complications derived from drug-drug interactions and drug resistance events. In this study, we intended to identify novel CAR inverse agonists or antagonists by screening a compound library of approved and experimental drugs. Using a set of cell-based assays, we have identified five approved drugs that antagonise the constitutive activity of CAR1 and CAR2 with $\mathrm{IC}_{50}$ values in the low micromolar range.

The original trans-activation assay for CARsv1 (CAR1) has been previously reported in the literature with a significant decrease in signals (10-fold) using the standard agonist PK11195 $(10 \mu \mathrm{M})$, however, it is commonly performed in 24 well plates and therefore needed to be adapted HTS application [122]. Campaigns of qHTS have previously miniaturised reporter assays up to 1536 well plates using stably transfected HepG2 cells with both CYP2B6 promoter/Luciferase gene and hCAR+A $[123,212]$. Within our current experimental setup, HEK293T cells were transiently transfected in suspension right before seeding in white 384 well plates. Despite modifications, our Z' values are acceptable and ranging on similarly described values (average Z' was 0.6 ).

Our primary screening identified 33 candidate antagonists. 10 candidate compounds were disregarded because of reducing effects on the activity of the co-transfected Renilla luciferase, which was used for data normalisation, thus indicating toxicity. Already known CAR inverse agonists, which emerged as candidates were not further tested, including daunorubicin, doxorubicin, bortezomib, adefovir and digoxin previously characterised by Lynch, clotrimazole and carvedilol $[118,123,213]$. On the other hand, methotrexate emerged as an antagonist candidate during our primary screening, however, it is reported in the literature as a CAR agonist, within hSULT2A1 promoter reporter assay [202], inducing sulfotransferase gene expression in human cells [201].

Other known CAR antagonists such as metformin [214] and nelfinavir [123], did not emerge as inhibitors in our primary screen. Diverging results for metformin are 
probably due to the lower and more physiologically relevant concentration used in our study compared to the $>500 \mu \mathrm{M}$ used by Yang and co-workers. According to [123] nelfinavir has $\mathrm{IC}_{50}$ around 9.5-11 $\mu \mathrm{M}$, tested on the stably transfected HepG2hCAR-CYP2B6 cell line, this divergence can be explained at least in part by the diverse physiological properties of different cell systems, since we have based our experiments in transient transfection, while Lynch employs a CAR1+A stable transfected cell line.

From the 13 compounds tested in dose-response experiments, eight hits did not confirm in dose-response experiments and therefore were excluded from further studies (clofarabine, cortisone, epirubicin, mechlorethamine, sorafenib sunitinib, tacrolimus and 6-thioguanine). Remaining five compounds confirmed as real inhibitors: pazopanib, miconazole, sulconazole, paclitaxel and gefitinib. Besides CAR1, all antagonists also potently inhibited the CAR2. In addition, paclitaxel, sulconazole and miconazole stimulated PXR activation.

All identified inhibitors represent true antagonists as all compounds disrupted the strong constitutive interaction of CAR and both co-activators DRIP205 and SRC1, the latter even in presence of the agonist CITCO. The compounds also reduced the SMRT interaction in higher extends than the known agonist CITCO. Furthermore, none of the compounds significantly induced the assembly of the CAR LBD, which indicates that these compounds exert their antagonistic effects via non-canonical binding sites on the LBD.

Azole derivatives are known to interfere with NR activity, the most studied example is ketoconazole, which is a potent inhibitor of PXR [203] and GR [215]. Ketoconazole is known to interfere with the recruitment of SRC1 by PXR, by binding to the AF-2 surface [149,203]. Additional derivatives include fluconazole [203], itraconazole and oxiconazole [204], reported as PXR antagonists, which however had no effect on CAR1 activation on our screening, and others such as miconazole and sulconazole which we identified as PXR agonists.

Miconazole which is known to act as a GR antagonist $\left(\mathrm{IC}_{50}=\sim 10 \mu \mathrm{M}\right)$ reducing its activation by dexamethasone, resulting in down regulation of CAR and PXR gene expression in hepatocytes which are under transcriptional control of GR [215]. Additionally, it has been shown antagonise PXR itself [203]. Here we report that miconazole inhibits the constitutive activity of both CAR1 and CAR2 and activates PXR at low micromolar concentrations. PXR activation by miconazole is controversial 
in the literature, one studies reported it to act as an antagonist at $25 \mu \mathrm{M}$ [203], another study suggests the compound to induce PXR with an $\mathrm{EC}_{50}$ value around $12 \mu \mathrm{M}$ [204]. Similarly, sulconazole antagonised CAR1 and CAR2 activation, while activated PXR at low micromolar concentrations, being cell toxic at the middle micromolar range.

In contrast to other NRs, CAR can be modulated also via indirect mechanisms, such as phosphorylation of Thr38 (DBD) by various kinases, which results in association with the extracellular signal-regulated kinase 1/2 (ERK1/2) or homodimerisation and, cytoplasmic sequestration by consequence [44,118,200]. Epidermal Growth Factor (EGF) represses CAR activation by stimulating the interaction with ERK1/2 and its homodimerization, therefore preventing its dephosphorylation [44]. Recently, the modulation of EGFR, and by consequence EGF activity, was identified as responsible for the CAR-inducing effect of metformin [214] and the phenobarbitalmediated indirect activation of CAR follows a similar mechanism [216]. Erlotinib (EGFR inhibitor) was able to induce dissociation of CAR homodimer on a cellular level, leading to nuclear translocation [200]. Interestingly, CAR can be also indirectly activated by phosphatases, such as the protein phosphatase 2Ac (PP2Ac) and the receptor-activated kinase 1 (RACK1) [216].

Gefinitib is known to also be a specific EGFR antagonist [217]. Inhibition of EGFR signalling results in RACK1 dephosphorylation which then recruits protein phosphatase 2Ac to the cytosol where phosphorylated CAR is localised. PP2Ac can dephosphorylate of CAR releasing it to the nuclear translocation. In this sense, any indirect effect of EGFR antagonist over CAR modulation would be its activation [216]. On the other hand, gefitinib could have its mechanism of action as an inverse agonist of CAR by modulating its phosphorylation state and therefore inhibiting its activity, but whether by EGFR-pathway or not remains to be clarified.

EGFR modulation itself is an issue, since some drugs, such as paclitaxel can modulate its expression levels. Paclitaxel is reported to produce an increase in EGFR protein level and phosphorylation activity, which could lead to a CAR indirect antagonism as mentioned above [218]. Another anti-cancer drug, paclitaxel is a known human and mice PXR agonist [135,219] and is here also demonstrated as human CAR antagonist.

On one hand, PXR activation by paclitaxel increases drugs resistance in several cancer cell lines, such as prostate and breast carcinomas [220] and it is known that 
phenobarbital can promote liver tumour in mice by activating CAR [221]. On the other hand, paclitaxel can also increase the antitumor efficacy on human lung cancer cells when administrated together with CAR agonists but has no further effect when coadministrated with androstenol, an inverse agonist [113].

As highlighted above, the role of CAR in carcinogenesis and consequently cancer therapy is under discussion and seems to be highly dependent on the tissue or cell type affected, due to indirect modulation mechanisms. Chemical structures of the classical antineoplastic agents, such as paclitaxel and gefitinib, could be modified in new derivatives to prevent these drugs from acting as CAR antagonists. Nevertheless, there is an entirely new field based on using CAR antagonists in combination with other drugs to increase its half-life or avoid hepatotoxicity caused by sub-products. 


\section{Concluding Remarks}

Nuclear receptors are an important protein family involved in many physiological processes and therefore attractive drug targets. There are many successful stories about nuclear receptor modulation by small molecules and several NRs drugs have been approved. As only a fraction of receptors is addressed by drugs, there is still a tremendous potential for future drug discovery. Despite the classical LBP capacity as interesting a drug-target, alternative approaches using other interaction sites on the protein surface suggest further possibilities for interference with nuclear receptors by small molecules.

This study provides evidence that CAR and PXR receptor inhibition by approved drugs may result in unwanted drug-drug interactions and also corroborates the existence of several ligand-binding sites on the LBD that allow different ligand interaction profiles and modulation.

Our validation protocol by cellular and in vitro assays, as well as molecular docking, suggests additional or exclusive binding outside the classical ligand binding pocket for most of the discovered ligands. In conclusion, we here have identified three approved drugs as novel potent PXR antagonists and five potential CAR inverse agonists with differential receptor interaction profiles. 


\section{References $^{1}$}

1. Owen GI, Zelent A. Origins and evolutionary diversification of the nuclear receptor superfamily. Cell Mol Life Sci. 2000;57(5):809-27.

2. Mangelsdorf DJ, Thummel C, Beato M, Herrlich P, Schutz G, Umesono K, et al. The nuclear receptor superfamily: the second decade. Cell. 1995;83(6):835-9.

3. Ashburner M, Chihara C, Meltzer P, Richards G. Temporal control of puffing activity in polytene chromosomes. Cold Spring Harb Symp Quant Biol. 1974;38:655-62.

4. Yamamoto KR. Steroid receptor regulated transcription of specific genes and gene networks. Annu Rev Genet. 1985;19:209-52.

5. Hollenberg SM, Weinberger C, Ong ES, Cerelli G, Oro A, Lebo R, et al. Primary structure and expression of a functional human glucocorticoid receptor cDNA. Nature. 1985;318(6047):635-41.

6. Green S, Walter P, Kumar V, Krust A, Bornert JM, Argos P, et al. Human oestrogen receptor cDNA: sequence, expression and homology to v-erb-A. Nature. $1986 ; 320(6058): 134-9$.

7. Miesfeld R, Rusconi S, Godowski PJ, Maler BA, Okret S, Wikstrom AC, et al. Genetic complementation of a glucocorticoid receptor deficiency by expression of cloned receptor cDNA. Cell. 1986;46(3):389-99.

8. Petkovich $\mathrm{M}$, Brand $\mathrm{NJ}$, Krust A, Chambon $\mathrm{P}$. A human retinoic acid receptor which belongs to the family of nuclear receptors. Nature. 1987;330(6147):444-50.

9. Evans RM. The steroid and thyroid hormone receptor superfamily. Science (80- ). 1988;240(4854):889-95.

10. Laudet V. Evolution of the nuclear receptor superfamily: early diversification from an ancestral orphan receptor. J Mol Endocrinol. 1997;19(3):207-26.

11. Nuclear Receptors Nomenclature C. A unified nomenclature system for the nuclear receptor superfamily. Cell. 1999;97(2):161-3.

12. Robinson-Rechavi M, Carpentier AS, Duffraisse M, Laudet V. How many nuclear hormone receptors are there in the human genome? Trends Genet. $2001 ; 17(10): 554-6$.

13. Zhou J, Cidlowski JA. The human glucocorticoid receptor: one gene, multiple proteins and diverse responses. Steroids. 2005;70(5-7):407-17.

14. Kornberg RD. Chromatin structure: a repeating unit of histones and DNA. Science (80- ). 1974;184(4139):868-71.

\footnotetext{
${ }^{1}$ According to: International Commitee of Medical Journal Editors. [Internet]. Uniform requirements for manuscripts submited to Biomedical Journal: sample references. [updated 2011 Jul 15]. Available from: http://www.icmje.org
} 
15. Chandler VL, Maler BA, Yamamoto KR. DNA sequences bound specifically by glucocorticoid receptor in vitro render a heterologous promoter hormone responsive in vivo. Cell. 1983;33(2):489-99.

16. Saatcioglu F, Bartunek P, Deng T, Zenke M, Karin M. A conserved C-terminal sequence that is deleted in v-ErbA is essential for the biological activities of c-ErbA (the thyroid hormone receptor). Mol Cell Biol. 1993;13(6):3675-85.

17. Belandia B, Latasa MJ, Villa A, Pascual A. Thyroid hormone negatively regulates the transcriptional activity of the beta-amyloid precursor protein gene. J Biol Chem. 1998;273(46):30366-71.

18. Perez-Juste G, Garcia-Silva S, Aranda A. An element in the region responsible for premature termination of transcription mediates repression of c-myc gene expression by thyroid hormone in neuroblastoma cells. $J$ Biol Chem. 2000;275(2):1307-14.

19. Beato $M$, Herrlich $P$, Schutz G. Steroid hormone receptors: many actors in search of a plot. Cell. 1995;83(6):851-7.

20. Juge-Aubry C, Pernin A, Favez T, Burger AG, Wahli W, Meier CA, et al. DNA binding properties of peroxisome proliferator-activated receptor subtypes on various natural peroxisome proliferator response elements. Importance of the 5'flanking region. J Biol Chem. 1997;272(40):25252-9.

21. Maher JM, Cheng X, Slitt AL, Dieter MZ, Klaassen CD. Induction of the multidrug resistance-associated protein family of transporters by chemical activators of receptor-mediated pathways in mouse liver. Drug Metab Dispos. 2005;33(7):95662.

22. Naar AM, Boutin JM, Lipkin SM, Yu VC, Holloway JM, Glass CK, et al. The orientation and spacing of core DNA-binding motifs dictate selective transcriptional responses to three nuclear receptors. Cell. 1991;65(7):1267-79.

23. Umesono K, Murakami KK, Thompson CC, Evans RM. Direct repeats as selective response elements for the thyroid hormone, retinoic acid, and vitamin D3 receptors. Cell. 1991;65(7):1255-66.

24. Kishimoto M, Fujiki R, Takezawa S, Sasaki Y, Nakamura T, Yamaoka K, et al. Nuclear receptor mediated gene regulation through chromatin remodeling and histone modifications. Endocr J. 2006;53(2):157-72.

25. Acevedo ML, Kraus WL. Transcriptional activation by nuclear receptors. Essays Biochem. 2004;40:73-88.

26. Chen JD, Evans RM. A transcriptional co-repressor that interacts with nuclear hormone receptors. Nature. 1995;377(6548):454-7.

27. Horlein AJ, Naar AM, Heinzel T, Torchia J, Gloss B, Kurokawa R, et al. Ligandindependent repression by the thyroid hormone receptor mediated by a nuclear receptor co-repressor. Nature. 1995;377(6548):397-404. 
28. Kraus WL, Wong J. Nuclear receptor-dependent transcription with chromatin. Is it all about enzymes? Eur J Biochem. 2002;269(9):2275-83.

29. Glass CK, Rosenfeld MG. The coregulator exchange in transcriptional functions of nuclear receptors. Genes Dev. 2000;14(2):121-41.

30. Leo C, Chen JD. The SRC family of nuclear receptor coactivators. Gene. $2000 ; 245(1): 1-11$.

31. Heery DM, Kalkhoven E, Hoare S, Parker MG. A signature motif in transcriptional co-activators mediates binding to nuclear receptors. Nature. 1997;387(6634):7336.

32. Darimont BD, Wagner RL, Apriletti JW, Stallcup MR, Kushner PJ, Baxter JD, et al. Structure and specificity of nuclear receptor-coactivator interactions. Genes Dev. 1998;12(21):3343-56.

33. Dilworth FJ, Chambon P. Nuclear receptors coordinate the activities of chromatin remodeling complexes and coactivators to facilitate initiation of transcription. Oncogene. 2001;20(24):3047-54.

34. Hsiao PW, Deroo BJ, Archer TK. Chromatin remodeling and tissue-selective responses of nuclear hormone receptors. Biochem Cell Biol. 2002;80(3):343-51.

35. Rachez C, Freedman LP. Mediator complexes and transcription. Curr Opin Cell Biol. 2001;13(3):274-80.

36. Brzozowski AM, Pike AC, Dauter Z, Hubbard RE, Bonn T, Engstrom O, et al. Molecular basis of agonism and antagonism in the oestrogen receptor. Nature. 1997;389(6652):753-8.

37. Jackson TA, Richer JK, Bain DL, Takimoto GS, Tung L, Horwitz KB. The partial agonist activity of antagonist-occupied steroid receptors is controlled by a novel hinge domain-binding coactivator L7/SPA and the corepressors N-CoR or SMRT. Mol Endocrinol. 1997;11(6):693-705.

38. Shiau AK, Barstad D, Loria PM, Cheng L, Kushner PJ, Agard DA, et al. The structural basis of estrogen receptor/coactivator recognition and the antagonism of this interaction by tamoxifen. Cell. 1998;95(7):927-37.

39. Aranda a, Aranda a, Pascual A, Pascual A. Nuclear hormone receptors and gene expression. Physiol Rev. 2001;81(3):1269-304.

40. Freedman LP, Luisi BF, Korszun ZR, Basavappa R, Sigler PB, Yamamoto KR. The function and structure of the metal coordination sites within the glucocorticoid receptor DNA binding domain. Nature. 1988;334(6182):543-6.

41. Hard T, Kellenbach E, Boelens R, Maler BA, Dahlman K, Freedman LP, et al. Solution structure of the glucocorticoid receptor DNA-binding domain. Science (80). 1990;249(4965):157-60. 
42. Luisi BF, Xu WX, Otwinowski Z, Freedman LP, Yamamoto KR, Sigler PB. Crystallographic analysis of the interaction of the glucocorticoid receptor with DNA. Nature. 1991;352(6335):497-505.

43. Schwabe JW, Chapman L, Finch JT, Rhodes D. The crystal structure of the estrogen receptor DNA-binding domain bound to DNA: how receptors discriminate between their response elements. Cell. 1993;75(3):567-78.

44. Mutoh S, Osabe M, Inoue K, Moore R, Pedersen L, Perera L, et al. Dephosphorylation of threonine 38 is required for nuclear translocation and activation of human xenobiotic receptor CAR (NR1I3). J Biol Chem. 2009 Dec $11 ; 284(50): 34785-92$.

45. Zenke M, Munoz A, Sap J, Vennstrom B, Beug H. v-erbA oncogene activation entails the loss of hormone-dependent regulator activity of c-erbA. Cell. 1990;61(6):1035-49.

46. Danielsen M. Bioinformatics of nuclear receptors. Methods Mol Biol. 2001;176:322.

47. Fawell SE, Lees JA, White R, Parker MG. Characterization and colocalization of steroid binding and dimerization activities in the mouse estrogen receptor. Cell. 1990;60(6):953-62.

48. Lees JA, Fawell SE, White R, Parker MG. A 22-amino-acid peptide restores DNAbinding activity to dimerization-defective mutants of the estrogen receptor. Mol Cell Biol. 1990;10(10):5529-31.

49. Picard D, Yamamoto KR. Two signals mediate hormone-dependent nuclear localization of the glucocorticoid receptor. EMBO J. 1987;6(11):3333-40.

50. Housley PR, Sanchez ER, Danielsen M, Ringold GM, Pratt WB. Evidence that the conserved region in the steroid binding domain of the glucocorticoid receptor is required for both optimal binding of hsp90 and protection from proteolytic cleavage. A two-site model for hsp90 binding to the steroid binding domain. J Biol Chem. 1990;265(22):12778-81.

51. Bourguet W, Ruff M, Chambon P, Gronemeyer H, Moras D. Crystal structure of the ligand-binding domain of the human nuclear receptor RXR-alpha. Nature. 1995;375(6530):377-82.

52. Wagner RL, Apriletti JW, McGrath ME, West BL, Baxter JD, Fletterick RJ. A structural role for hormone in the thyroid hormone receptor. Nature. $1995 ; 378(6558): 690-7$.

53. Wurtz JM, Bourguet W, Renaud JP, Vivat V, Chambon P, Moras D, et al. A canonical structure for the ligand-binding domain of nuclear receptors. Nat Struct Biol. 1996;3(2):206.

54. Renaud JP, Rochel N, Ruff M, Vivat V, Chambon P, Gronemeyer H, et al. Crystal structure of the RAR-gamma ligand-binding domain bound to all-trans retinoic acid. Nature. 1995;378(6558):681-9. 
55. Nolte RT, Wisely GB, Westin S, Cobb JE, Lambert MH, Kurokawa R, et al. Ligand binding and co-activator assembly of the peroxisome proliferator-activated receptor-gamma. Nature. 1998;395(6698):137-43.

56. Greschik H, Wurtz JM, Sanglier S, Bourguet W, van Dorsselaer A, Moras D, et al. Structural and functional evidence for ligand-independent transcriptional activation by the estrogen-related receptor 3. Mol Cell. 2002;9(2):303-13.

57. Kallen J, Schlaeppi JM, Bitsch F, Filipuzzi I, Schilb A, Riou V, et al. Evidence for ligand-independent transcriptional activation of the human estrogen-related receptor alpha (ERRalpha): crystal structure of ERRalpha ligand binding domain in complex with peroxisome proliferator-activated receptor coactivator-1alpha. J Biol Chem. 2004;279(47):49330-7.

58. de Vera IMS, Giri PK, Munoz-Tello P, Brust R, Fuhrmann J, Matta-Camacho E, et al. Identification of a Binding Site for Unsaturated Fatty Acids in the Orphan Nuclear Receptor Nurr1. ACS Chem Biol. 2016 Jul 15;11(7):1795-9.

59. Glickman JF, Wu X, Mercuri R, Illy C, Bowen BR, He Y, et al. A comparison of ALPHAScreen, TR-FRET, and TRF as assay methods for FXR nuclear receptors. Picard D, editor. J Biomol Screen. 3rd ed. 2002 May 11;7(1):3-10.

60. Wang D-Y, Fulthorpe R, Liss SN, Edwards EA. Identification of estrogenresponsive genes by complementary deoxyribonucleic acid microarray and characterization of a novel early estrogen-induced gene: EEIG1. Mol Endocrinol. 2004 Feb;18(2):402-11.

61. Jordan VC. Fourteenth Gaddum Memorial Lecture. A current view of tamoxifen for the treatment and prevention of breast cancer. $\mathrm{Br} J$ Pharmacol. 1993 Oct;110(2):507-17.

62. Braems G, Denys $H$, De Wever O, Cocquyt V, Van den Broecke R. Use of tamoxifen before and during pregnancy. Oncologist. 2011 Nov 1;16(11):1547-51.

63. Bledsoe RK, Montana VG, Stanley TB, Delves CJ, Apolito CJ, McKee DD, et al. Crystal structure of the glucocorticoid receptor ligand binding domain reveals a novel mode of receptor dimerization and coactivator recognition. Cell. $2002 \mathrm{Jul}$ 12;110(1):93-105.

64. Kauppi B, Jakob C, Färnegårdh M, Yang J, Ahola H, Alarcon M, et al. The threedimensional structures of antagonistic and agonistic forms of the glucocorticoid receptor ligand-binding domain: $\mathrm{RU}-486$ induces a transconformation that leads to active antagonism. J Biol Chem. 2003 Jun 20;278(25):22748-54.

65. Elmore SW, Pratt JK, Coghlan MJ, Mao Y, Green BE, Anderson DD, et al. Differentiation of in vitro transcriptional repression and activation profiles of selective glucocorticoid modulators. Bioorg Med Chem Lett. 2004 Apr $5 ; 14(7): 1721-7$.

66. Coghlan MJ, Jacobson PB, Lane B, Nakane M, Lin CW, Elmore SW, et al. A Novel Antiinflammatory Maintains Glucocorticoid Efficacy with Reduced Side Effects. Mol 
Endocrinol. 2003 May;17(5):860-9.

67. Lu NZ, Wardell SE, Burnstein KL, Defranco D, Fuller PJ, Giguere V, et al. International Union of Pharmacology. LXV. The pharmacology and classification of the nuclear receptor superfamily: glucocorticoid, mineralocorticoid, progesterone, and androgen receptors. Pharmacol Rev. 2006 Dec 1;58(4):782-97.

68. He B, Kemppainen JA, Voegel JJ, Gronemeyer H, Wilson EM. Activation function 2 in the human androgen receptor ligand binding domain mediates interdomain communication with the $\mathrm{NH}(2)$-terminal domain. J Biol Chem. $1999 \mathrm{Dec}$ 24;274(52):37219-25.

69. Shore ND, Abrahamsson P-A, Anderson J, Crawford ED, Lange P. New considerations for ADT in advanced prostate cancer and the emerging role of GnRH antagonists. Prostate Cancer Prostatic Dis. 2013 Mar 3;16(1):7-15.

70. Nemes A, Tomuleasa C, Kacso G. The androgen receptor remains a key player in metastatic hormone-refractory prostate cancer. Implications for new treatments. $\mathrm{J}$ BUON. 19(2):357-64.

71. Tran C, Ouk S, Clegg NJ, Chen Y, Watson PA, Arora V, et al. Development of a second-generation antiandrogen for treatment of advanced prostate cancer. Science. 2009 May 8;324(5928):787-90.

72. Saad F. Evidence for the efficacy of enzalutamide in postchemotherapy metastatic castrate-resistant prostate cancer. Ther Adv Urol. 2013 Aug;5(4):201-10.

73. Li H, Ban F, Dalal K, Leblanc E, Frewin K, Ma D, et al. Discovery of smallmolecule inhibitors selectively targeting the DNA-binding domain of the human androgen receptor. J Med Chem. 2014 Aug 14;57(15):6458-67.

74. Dalal K, Roshan-Moniri M, Sharma A, Li H, Ban F, Hassona MD, et al. Selectively targeting the DNA-binding domain of the androgen receptor as a prospective therapy for prostate cancer. J Biol Chem. 2014 Sep 19;289(38):26417-29.

75. Berger J, Moller DE. The mechanisms of action of PPARs. Annu Rev Med. 2002;53:409-35.

76. Batista FA, Trivella DB, Bernardes A, Gratieri J, Oliveira PS, Figueira AC, et al. Structural insights into human peroxisome proliferator activated receptor delta (PPAR-delta) selective ligand binding. PLoS One. 2012;7(5):e33643.

77. Da Silva FMC, Dos Santos JC, Campos JLO, Mafud AC, Polikarpov I, Figueira ACM, et al. Structure-based identification of novel PPAR gamma ligands. Bioorganic Med Chem Lett. 2013;23(21):5795-802.

78. Markt P, Petersen RK, Flindt EN, Kristiansen K, Kirchmair J, Spitzer G, et al. Discovery of Novel PPAR Ligands by a Virtual Screening Approach Based on Pharmacophore Modeling, 3D Shape, and Electrostatic Similarity Screening. J Med Chem. 2008 Oct 23;51(20):6303-17.

79. Xu HE, Lambert MH, Montana VG, Parks DJ, Blanchard SG, Brown PJ, et al. 
Molecular recognition of fatty acids by peroxisome proliferator-activated receptors. Mol Cell. 1999;3(3):397-403.

80. Song $\mathrm{C}-\mathrm{H}$, Yang SH, Park E, Cho SH, Gong E-Y, Khadka DB, et al. Structurebased Virtual Screening and Identification of a Novel Androgen Receptor Antagonist. J Biol Chem. 2012;287(36):30769-80.

81. Lewis SN, Bassaganya-riera J, Bevan DR. Virtual Screening as a Technique for PPAR Modulator Discovery. 2010;2010.

82. Maltarollo VG, Togashi M, Nascimento AS, Honorio KM. Structure-based virtual screening and discovery of New PPAR $/ \mathrm{Y}$ dual agonist and PPARס and $\mathrm{Y}$ agonists. PLoS One. 2015 Jan;10(3):e0118790.

83. Activating agent for peroxisome proliferator activated receptor $\delta .2007$;

84. Miyachi H. Design, synthesis, and structure-activity relationship study of peroxisome proliferator-activated receptor (PPAR) delta-selective ligands. Curr Med Chem. 2007;14(22):2335-43.

85. Oliver WR, Shenk JL, Snaith MR, Russell CS, Plunket KD, Bodkin NL, et al. A selective peroxisome proliferator-activated receptor delta agonist promotes reverse cholesterol transport. Proc Natl Acad Sci U S A. 2001 Apr 24;98(9):530611.

86. Lim H, Gupta RA, Ma WG, Paria BC, Moller DE, Morrow JD, et al. Cyclooxygenase-2-derived prostacyclin mediates embryo implantation in the mouse via PPARdelta. Genes Dev. 1999 Jun 15;13(12):1561-74.

87. He TC, Chan TA, Vogelstein B, Kinzler KW. PPARdelta is an APC-regulated target of nonsteroidal anti-inflammatory drugs. Cell. 1999 Oct 29;99(3):335-45.

88. Gupta RA, Tan J, Krause WF, Geraci MW, Willson TM, Dey SK, et al. Prostacyclin-mediated activation of peroxisome proliferator-activated receptor delta in colorectal cancer. Proc Natl Acad Sci U S A. 2000 Nov 21;97(24):1327580.

89. Tenenbaum A, Motro M, Fisman EZ. Dual and pan-peroxisome proliferatoractivated receptors (PPAR) co-agonism: the bezafibrate lessons. Cardiovasc Diabetol. 2005 Sep 16;4:14.

90. Tenenbaum A, Motro M, Fisman EZ, Schwammenthal E, Adler Y, Goldenberg I, et al. Peroxisome proliferator-activated receptor ligand bezafibrate for prevention of type 2 diabetes mellitus in patients with coronary artery disease. Circulation. 2004 May 11;109(18):2197-202.

91. Schuetz EG, Beck WT, Schuetz JD. Modulators and substrates of P-glycoprotein and cytochrome P4503A coordinately up-regulate these proteins in human colon carcinoma cells. Mol Pharmacol. 1996;49(2):311-8.

92. Timsit YE, Negishi M. CAR and PXR: the xenobiotic-sensing receptors. Steroids. 2007 Mar;72(3):231-46. 
93. Chai SC, Cherian MT, Wang Y-M, Chen T. Small-molecule modulators of PXR and CAR. Biochim Biophys Acta - Gene Regul Mech. 2016;

94. Burk O, Arnold KA, Geick A, Tegude H, Eichelbaum M. A role for constitutive androstane receptor in the regulation of human intestinal MDR1 expression. Biol Chem. 2005 Jun;386(6):503-13.

95. Moore JT, Collins JL, Pearce KH. The nuclear receptor superfamily and drug discovery. ChemMedChem. 2006;1(5):504-23.

96. Forman BM, Tzameli I, Choi HS, Chen J, Simha D, Seol W, et al. Androstane metabolites bind to and deactivate the nuclear receptor CAR-beta. Nature. $1998 ; 395(6702): 612-5$.

97. Willson TM, Kliewer S a. PXR, CAR and drug metabolism. Nat Rev Drug Discov. 2002;1(4):259-66.

98. Stanley LA, Horsburgh BC, Ross J, Scheer N, Wolf CR. PXR and CAR: nuclear receptors which play a pivotal role in drug disposition and chemical toxicity. Drug Metab Rev. 2006 Jan;38(3):515-97.

99. Baes M, Gulick T, Choi HS, Martinoli MG, Simha D, Moore DD. A new orphan member of the nuclear hormone receptor superfamily that interacts with a subset of retinoic acid response elements. Mol Cell Biol. 1994;14(3):1544-52.

100. Wei P, Zhang J, Egan-Hafley M, Liang S, Moore DD. The nuclear receptor CAR mediates specific xenobiotic induction of drug metabolism. Nature. 2000;407(6806):920-3.

101. Wei P, Zhang J, Dowhan DH, Han Y, Moore DD. Specific and overlapping functions of the nuclear hormone receptors CAR and PXR in xenobiotic response. Pharmacogenomics J. 2002 Apr 30;2(2):117-26.

102. Arnold L a., Kosinski A, Estebanez-Perpina E, Fletterick RJ, Guy RK, EstébanezPerpiñá $E$, et al. Inhibitors of the interaction of a thyroid hormone receptor and coactivators: preliminary structure-activity relationships. $\mathrm{J}$ Med Chem. 2007;50(22):5269-80.

103. Lamba JK, Lamba V, Yasuda K, Lin YS, Assem M, Thompson E, et al. Expression of constitutive androstane receptor splice variants in human tissues and their functional consequences. J Pharmacol Exp Ther. 2004 Nov 5;311(2):811-21.

104. Sueyoshi T, Kawamoto T, Zelko I, Honkakoski P, Negishi M. The repressed nuclear receptor CAR responds to phenobarbital in activating the human CYP2B6 gene. J Biol Chem. 1999;274(10):6043-6.

105. Honkakoski P, Zelko I, Sueyoshi T, Negishi M. The nuclear orphan receptor CARretinoid $X$ receptor heterodimer activates the phenobarbital-responsive enhancer module of the CYP2B gene. Mol Cell Biol. 1998;18(10):5652-8.

106. DeKeyser JG, Stagliano MC, Auerbach SS, Prabhu KS, Jones AD, Omiecinski CJ. 
Di(2-ethylhexyl) phthalate is a highly potent agonist for the human constitutive androstane receptor splice variant CAR2. Mol Pharmacol. 2009 May;75(5):100513.

107. Takwi AA, Wang Y-M, Wu J, Michaelis M, Cinatl J, Jr., et al. miR-137 regulates the constitutive androstane receptor and modulates doxorubicin sensitivity in parental and doxorubicin-resistant neuroblastoma cells. Oncogene. 2014;33(28):3717.

108. Zhang J, Huang W, Chua SS, Wei P, Moore DD. Modulation of AcetaminophenInduced Hepatotoxicity by the Xenobiotic Receptor CAR. Science (80- ). 2002;298(5592).

109. Kobayashi K, Sueyoshi T, Inoue K, Moore R, Negishi M. Cytoplasmic accumulation of the nuclear receptor CAR by a tetratricopeptide repeat protein in HepG2 cells. Mol Pharmacol. 2003 Nov;64(5):1069-75.

110. Kohalmy K, Tamási V, Kóbori L, Sárváry E, Pascussi J-M, Porrogi $P$, et al. Dehydroepiandrosterone induces human CYP2B6 through the constitutive androstane receptor. Drug Metab Dispos. 2007 Sep 1;35(9):1495-501.

111. Ueda A, Hamadeh HK, Webb HK, Yamamoto Y, Sueyoshi T, Afshari CA, et al. Diverse roles of the nuclear orphan receptor CAR in regulating hepatic genes in response to phenobarbital. Mol Pharmacol. 2002 Jan;61(1):1-6.

112. Moreau A, Vilarem MJ, Maurel P, Pascussi JM. Xenoreceptors CAR and PXR Activation and Consequences on Lipid Metabolism, Glucose Homeostasis, and Inflammatory Response. Mol Pharm. 2008 Feb;5(1):35-41.

113. Fukumasu H, Rochetti AL, Pires PRL, Silva ER, Mesquita LG, Strefezzi RF, et al. Constitutive androstane receptor ligands modulate the anti-tumor efficacy of paclitaxel in non-small cell lung cancer cells. PLoS One. 2014;9(6):1-10.

114. Gupta D, Venkatesh M, Wang H, Kim S, Sinz M, Goldberg GL, et al. Expanding the roles for pregnane $X$ receptor in cancer: Proliferation and drug resistance in ovarian cancer. Clin Cancer Res. 2008;14(17):5332-40.

115. Auerbach SS, Ramsden R, Stoner MA, Verlinde C, Hassett C, Omiecinski CJ. Alternatively spliced isoforms of the human constitutive androstane receptor. Nucleic Acids Res. 2003 Jun 15;31(12):3194-207.

116. Arnold $\mathrm{KA}$, Eichelbaum $\mathrm{M}$, Burk $\mathrm{O}$. Alternative splicing affects the function and tissue-specific expression of the human constitutive androstane receptor. Nucl Recept. 2004;2(1):1.

117. Auerbach SS, Ramsden R, Stoner M a., Verlinde C, Hassett C, Omiecinski CJ. Alternatively spliced isoforms of the human constitutive androstane receptor. Nucleic Acids Res. 2003;31(12):3194-207.

118. Moore LB, Parks DJ, Jones SA, Bledsoe RK, Consler TG, Stimmel JB, et al. Orphan nuclear receptors constitutive androstane receptor and pregnane $X$ receptor share xenobiotic and steroid ligands. J Biol Chem. 2000 May 19;275(20):15122-7. 
119. Lau AJ, Yang G, Rajaraman G, Baucom CC, Chang TKH. Differential effect of meclizine on the activity of human pregnane $X$ receptor and constitutive androstane receptor. J Pharmacol Exp Ther. 2011 Mar;336(3):816-26.

120. Auerbach SS, Stoner MA, Su S, Omiecinski CJ. Retinoid X receptor-alphadependent transactivation by a naturally occurring structural variant of human constitutive androstane receptor (NR1/3). Mol Pharmacol. 2005 Nov;68(5):1239_ 53.

121. Chen T, Tompkins LM, Li L, Li H, Kim G, Zheng $Y$, et al. A single amino acid controls the functional switch of human constitutive androstane receptor (CAR) 1 to the xenobiotic-sensitive splicing variant CAR3. J Pharmacol Exp Ther. 2010 Jan;332(1):106-15.

122. Li L, Chen T, Stanton JD, Sueyoshi T, Negishi M, Wang H. The Peripheral Benzodiazepine Receptor Ligand 1-(2-Chlorophenyl-methylpropyl)-3-isoquinolinecarboxamide Is a Novel Antagonist of Human Constitutive Androstane Receptor. Mol Pharmacol. 2008 May 20;74(2):443-53.

123. Lynch C, Zhao J, Huang R, Xiao J, Li L, Heyward S, et al. Quantitative HighThroughput Identification of Drugs as Modulators of Human Constitutive Androstane Receptor. Sci Rep. 2015 Jan;5(April):10405.

124. Huang W, Zhang J, Wei P, Schrader WT, Moore DD. Meclizine is an agonist ligand for mouse constitutive androstane receptor (CAR) and an inverse agonist for human CAR. Mol Endocrinol. 2004;18(10):2402-8.

125. Cherian MT, Yang L, Chai SC, Lin W, Chen T. Identification and Characterization of CINPA1 Metabolites Facilitates Structure-Activity Studies of the Constitutive Androstane Receptor. Drug Metab Dispos. 2016 Nov;44(11):1759-70.

126. Lin W, Yang L, Chai SC, Lu Y, Chen T. Development of CINPA1 analogs as novel and potent inverse agonists of constitutive androstane receptor. Eur $\mathrm{J}$ Med Chem. 2016;108:505-28.

127. Handschin C, Meyer UA. Induction of drug metabolism: the role of nuclear receptors. PharmacolRev. 2003;55(0031-6997 (Print) LA-eng PT-Journal Article PT-Review RN-0 (Pharmaceutical Preparations) RN-0 (Receptors, Cytoplasmic and Nuclear) RN-9035-51-2 (Cytochrome P-450 Enzyme System) SB-IM):649_ 73.

128. Wang Y-M, Ong SS, Chai SC, Chen T. Role of CAR and PXR in xenobiotic sensing and metabolism. Expert Opin Drug Metab Toxicol. 2012 Jul;8(7):803-17.

129. Burk O, Arnold KA, Nussler AK, Schaeffeler E, Efimova E, Avery BA, et al. Antimalarial Artemisinin Drugs Induce Cytochrome P450 and MDR1 Expression by Activation of Xenosensors Pregnane $X$ Receptor and Constitutive Androstane Receptor. Mol Pharmacol. 2005 Jun;67(6):1954-65.

130. Kliewer S, Moore J, Wade L, Staudinger J, Watson M, Jones S, et al. An orphan nuclear receptor activated by pregnanes defines a novel steroid signaling pathway. 
Cell. 1998;9(1):73-82.

131. Lehmann JM, McKee DD, Watson MA, Willson TM, Moore JT, Kliewer SA. The human orphan nuclear receptor PXR is activated by compounds that regulate CYP3A4 gene expression and cause drug interactions. J Clin Invest. 1998 Sep 1;102(5):1016-23.

132. Sinz M, Kim S, Zhu Z, Chen T, Anthony M, Dickinson K, et al. Evaluation of 170 xenobiotics as transactivators of human pregnane $X$ receptor (hPXR) and correlation to known CYP3A4 drug interactions. Curr Drug Metab. 2006 May;7(4):375-88.

133. Chen T. Overcoming drug resistance by regulating nuclear receptors. Adv Drug Deliv Rev. 2010 Oct 30;62(13):1257-64.

134. Ratajewski M, Grzelak I, Wiśniewska K, Ryba K, Gorzkiewicz M, WalczakDrzewiecka $A$, et al. Screening of a chemical library reveals novel PXR-activating pharmacologic compounds. Toxicol Lett. 2015;232(1):193-202.

135. Synold TW, Dussault I, Forman BM. The orphan nuclear receptor SXR coordinately regulates drug metabolism and efflux. Nat Med. 2001 May;7(5):58490.

136. Zhou C, Poulton E-J, Grün F, Bammler TK, Blumberg B, Thummel KE, et al. The dietary isothiocyanate sulforaphane is an antagonist of the human steroid and xenobiotic nuclear receptor. Mol Pharmacol. 2007 Jan;71(1):220-9.

137. Wang H, Li H, Moore LB, Johnson MDL, Maglich JM, Goodwin B, et al. The phytoestrogen coumestrol is a naturally occurring antagonist of the human pregnane X receptor. Mol Endocrinol. 2008 Apr;22(4):838-57.

138. Ekins S, Kholodovych V, Ai N, Sinz M, Gal J, Gera L, et al. Computational discovery of novel low micromolar human pregnane $X$ receptor antagonists. Mol Pharmacol. 2008 Sep;74(3):662-72.

139. Chen Y, Tang Y, Robbins GT, Nie D. Camptothecin attenuates cytochrome P450 3A4 induction by blocking the activation of human pregnane $X$ receptor. $J$ Pharmacol Exp Ther. 2010 Sep 1;334(3):999-1008.

140. Liu C-L, Lim Y-P, Hu M-L. Fucoxanthin attenuates rifampin-induced cytochrome P450 3A4 (CYP3A4) and multiple drug resistance 1 (MDR1) gene expression through pregnane $X$ receptor (PXR)-mediated pathways in human hepatoma HepG2 and colon adenocarcinoma LS174T cells. Mar Drugs. 2012 Jan;10(1):24257.

141. Lim Y-P, Ma C-Y, Liu C-L, Lin Y-H, Hu M-L, Chen J-J, et al. Sesamin: A Naturally Occurring Lignan Inhibits CYP3A4 by Antagonizing the Pregnane $X$ Receptor Activation. Evid Based Complement Alternat Med. 2012;2012:242810.

142. Tabb MM, Kholodovych V, Grün F, Zhou C, Welsh WJ, Blumberg B. Highly chlorinated PCBs inhibit the human xenobiotic response mediated by the steroid and xenobiotic receptor (SXR). Environ Health Perspect. 2004 Feb;112(2):163-9. 
143. Healan-Greenberg C, Waring J, Kempf D, Blomme E, Tirona R, Kim R. A human immunodeficiency virus protease inhibitor is a novel functional inhibitor of human pregnane X receptor. Drug Metab Dispos. 2008;36(3):500-7.

144. Das B, Madhukumar A, Anguiano J, Kim S, Sinz M, Zvyaga T, et al. Synthesis of novel ketoconazole derivatives as inhibitors of the human Pregnane $X$ Receptor (PXR; NR1I2; also termed SXR, PAR). Bioorg Med Chem Lett. 2008;15(18):39747.

145. Venkatesh $\mathrm{M}$, Wang $\mathrm{H}$, Cayer J, Leroux M, Salvail D, Das B, et al. In vivo and in vitro characterization of a first-in-class novel azole analog that targets pregnane $X$ receptor activation. Mol Pharmacol. 2011 Jul;80(1):124-35.

146. Takeshita A, Taguchi M, Koibuchi N, Ozawa Y. Putative role of the orphan nuclear receptor SXR (steroid and xenobiotic receptor) in the mechanism of CYP3A4 inhibition by xenobiotics. J Biol Chem. 2002 Sep 6;277(36):32453-8.

147. Krausova L, Stejskalova L, Wang H, Vrzal R, Dvorak Z, Mani S, et al. Metformin suppresses pregnane $X$ receptor (PXR)-regulated transactivation of CYP3A4 gene. Biochem Pharmacol. 2011;1(82(11)):1771-80.

148. Tice CM, Zheng Y-J. Non-canonical modulators of nuclear receptors. Bioorg Med Chem Lett. 2016;

149. Huang $\mathrm{H}$, Wang $\mathrm{H}$, Sinz $\mathrm{M}$, Zoeckler $\mathrm{M}$, Staudinger J, Redinbo MR, et al. Inhibition of drug metabolism by blocking the activation of nuclear receptors by ketoconazole. Oncogene. 2007;26(2):258-68.

150. Zhuo W, Hu L, Lv J, Wang H, Zhou H, Fan L. Role of pregnane $\mathrm{X}$ receptor in chemotherapeutic treatment. Cancer Chemother Pharmacol. 2014 Aug 3;74(2):217-27.

151. McEwan IJ. Nuclear Receptors: One Big Family. In: Methods in molecular biology (Clifton, NJ). 2009. p. 3-18.

152. Read JT, Cheng H, Hendy SC, Nelson CC, Rennie PS. Receptor-DNA interactions: EMSA and footprinting. Methods Mol Biol. 2009;505:97-122.

153. Goodson ML, Farboud B, Privalsky ML. High throughput analysis of nuclear receptor-cofactor interactions. Methods Mol Biol. 2009;505:157-69.

154. Berno V, Hinojos CA, Amazit L, Szafran AT, Mancini MA. High-resolution, highthroughput microscopy analyses of nuclear receptor and coregulator function. Methods Enzymol. 2006;414:188-210.

155. Hartig SM, Newberg JY, Bolt MJ, Szafran AT, Marcelli M, Mancini MA. Automated microscopy and image analysis for androgen receptor function. Methods Mol Biol. $2011 ; 776: 313-31$.

156. Jones SA, Moore LB, Shenk JL, Wisely GB, Hamilton GA, McKee DD, et al. The pregnane $X$ receptor: a promiscuous xenobiotic receptor that has diverged during 
evolution. Mol Endocrinol. 2000 Jan;14(1):27-39.

157. Krey G, Braissant O, L'Horset F, Kalkhoven E, Perroud M, Parker MG, et al. Fatty acids, eicosanoids, and hypolipidemic agents identified as ligands of peroxisome proliferator-activated receptors by coactivator-dependent receptor ligand assay. Mol Endocrinol. 1997 Jun;11(6):779-91.

158. Hughes TS, Chalmers MJ, Novick S, Kuruvilla DS, Chang MR, Kamenecka TM, et al. Ligand and receptor dynamics contribute to the mechanism of graded PPARY agonism. Structure. 2012 Jan 11;20(1):139-50.

159. Johnson BA, Wilson EM, Li Y, Moller DE, Smith RG, Zhou G. Ligand-induced stabilization of PPARgamma monitored by NMR spectroscopy: implications for nuclear receptor activation. J Mol Biol. 2000 Apr 28;298(2):187-94.

160. Kojetin DJ, Burris TP. Small molecule modulation of nuclear receptor conformational dynamics: implications for function and drug discovery. Mol Pharmacol. 2013 Jan 1;83(1):1-8.

161. Lavery DN. Binding affinity and kinetic analysis of nuclear receptor/co-regulator interactions using surface plasmon resonance. Methods Mol Biol. 2009;505:17186.

162. Chu V, Einolf HJ, Evers R, Kumar G, Moore D, Ripp S, et al. In vitro and in vivo induction of cytochrome p450: a survey of the current practices and recommendations: a pharmaceutical research and manufacturers of america perspective. Drug Metab Dispos. 2009 Jul;37(7):1339-54.

163. Raucy JL, Lasker JM. Cell-based systems to assess nuclear receptor activation and their use in drug development. Drug Metab Rev. 2013 Feb;45(1):101-9.

164. Sinz M, Kim S, Zhu Z, Chen T, Anthony M, Dickinson K, et al. Evaluation of 170 xenobiotics as transactivators of human pregnane $X$ receptor (hPXR) and correlation to known CYP3A4 drug interactions. Curr Drug Metab. 2006 May;7(4):375-88.

165. Dring AM, Anderson LE, Qamar S, Stoner MA. Rational quantitative structureactivity relationship (RQSAR) screen for PXR and CAR isoform-specific nuclear receptor ligands. Chem Biol Interact. 2010 Dec 5;188(3):512-25.

166. Luo G, Cunningham M, Kim S, Burn T, Lin J, Sinz M, et al. CYP3A4 induction by drugs: correlation between a pregnane $X$ receptor reporter gene assay and CYP3A4 expression in human hepatocytes. Drug Metab Dispos. 2002 Jul;30(7):795-804.

167. di Masi A, De Marinis E, Ascenzi P, Marino M. Nuclear receptors CAR and PXR: Molecular, functional, and biomedical aspects. Mol Aspects Med. 2009 Oct;30(5):297-343.

168. Yueh M-F, Kawahara M, Raucy J. High volume bioassays to assess CYP3A4mediated drug interactions: induction and inhibition in a single cell line. Drug Metab Dispos. 2005 Jan;33(1):38-48. 
169. Fahmi OA, Raucy JL, Ponce E, Hassanali S, Lasker JM. Utility of DPX2 cells for predicting CYP3A induction-mediated drug-drug interactions and associated structure-activity relationships. Drug Metab Dispos. 2012 Nov 1;40(11):2204-11.

170. Shukla SJ, Sakamuru S, Huang R, Moeller TA, Shinn P, Vanleer D, et al. Identification of clinically used drugs that activate pregnane $X$ receptors. Drug Metab Dispos. 2011 Jan;39(1):151-9.

171. Cherian MT, Yang L, Chai SC, Lin W, Chen T. Identification and Characterization of CINPA1 Metabolites Facilitates Structure-Activity Studies of the Constitutive Androstane Receptor. Drug Metab Dispos. 2016;44(11).

172. Jeske J, Windshügel $B$, Thasler WE, Schwab $M$, Burk O. Human pregnane $X$ receptor is activated by dibenzazepine carbamate-based inhibitors of constitutive androstane receptor. Arch Toxicol. 2017 Mar 13;1-16.

173. Chen T, Xie W, Agler M, Banks M. Coactivators in assay design for nuclear hormone receptor drug discovery. Assay Drug Dev Technol. 2003 Dec;1(6):83542.

174. Honkakoski $P$, Jääskeläinen I, Kortelahti M, Urtti A. A novel drug-regulated gene expression system based on the nuclear receptor constitutive androstane receptor (CAR). Pharm Res. 2001 Feb;18(2):146-50.

175. Burk O, Piedade R, Ghebreghiorghis L, Fait JT, Nussler AK, Gil JP, et al. Differential effects of clinically used derivatives and metabolites of artemisinin in the activation of constitutive androstane receptor isoforms. $\mathrm{Br} J$ Pharmacol. 2012;167(3):666-81.

176. Estebanez-Perpina E, Arnold LA, Nguyen P, Rodrigues ED, Mar E, Bateman R, et al. A surface on the androgen receptor that allosterically regulates coactivator binding. Proc Natl Acad Sci U S A. 2007;104(41):16074-9.

177. Iversen PW, Eastwood BJ, Sittampalam GS, Cox KL. A comparison of assay performance measures in screening assays: signal window, Z' factor, and assay variability ratio. J Biomol Screen Off J Soc Biomol Screen. 2006;11(3):247-52.

178. Wu X, Glickman JF, Bowen BR, Sills MA. Comparison of assay technologies for a nuclear receptor assay screen reveals differences in the sets of identified functional antagonists. J Biomol Screen. 2003;8(4):381-92.

179. Rouleau N, Bossé R, Hemmilä I. Development of Nuclear Receptor Homogeneous Assay Using the LanceTM Technology. In: Minor: Handbook of Assay Development in Drug Discovery. New York: CRC Taylor \& Francis; 2006. p. 20919.

180. Tremblay GB, Kunath T, Bergeron D, Lapointe L, Champigny C, Bader JA, et al. Diethylstilbestrol regulates trophoblast stem cell differentiation as a ligand of orphan nuclear receptor ERR beta. Genes Dev. 2001 Apr 1;15(7):833-8.

181. Drake KA, Zhang J-H, Harrison RK, McGeehan GM. Development of a 
homogeneous, fluorescence resonance energy transfer-based in vitro recruitment assay for peroxisome proliferator-activated receptor delta via selection of active LXXLL coactivator peptides. Anal Biochem. 2002 May 1;304(1):63-9.

182. Liu J, Knappenberger KS, Kack H, Andersson G, Nilsson E, Dartsch C, et al. A homogeneous in vitro functional assay for estrogen receptors: coactivator recruitment. Mol Endocrinol. 2003 Mar;17(3):346-55.

183. Jones SA, Parks DJ, Kliewer SA. Cell-free ligand binding assays for nuclear receptors. Methods Enzymol. 2003;364:53-71.

184. Schapira M, Abagyan R, Totrov M. Nuclear Hormone Receptor Targeted Virtual Screening. J Med Chem. 2003 Jul 3;46(14):3045-59.

185. Hustert E, Zibat A, Presecan-Siedel E, Eiselt R, Mueller R, Fu\{beta\} C, et al. Natural Protein Variants of Pregnane X Receptor with Altered Transactivation Activity Toward CYP3A4. Drug Metab Dispos. 2001 Nov 1;29(11):1454-9.

186. Bros $M$, Ross X-L, Pautz A, Reske-Kunz AB, Ross R. The human fascin gene promoter is highly active in mature dendritic cells due to a stage-specific enhancer. J Immunol. 2003 Aug 15;171(4):1825-34.

187. Zhu Z, Kim S, Chen T, Lin J-H, Bell A, Bryson J, et al. Correlation of highthroughput pregnane $X$ receptor (PXR) transactivation and binding assays. $J$ Biomol Screen Off J Soc Biomol Screen. 2004;9(6):533-40.

188. Burk O, Tegude H, Koch I, Hustert E, Wolbold R, Glaeser H, et al. Molecular mechanisms of polymorphic CYP3A7 expression in adult human liver and intestine. J Biol Chem. 2002 Jul 5;277(27):24280-8.

189. Lee SML, Schelcher C, Demmel M, Hauner M, Thasler WE. Isolation of Human Hepatocytes by a Two-step Collagenase Perfusion Procedure. J Vis Exp. 2013 Sep 3;(79).

190. Thasler WE, Weiss TS, Schillhorn K, Stoll P-T, Irrgang B, Jauch K-W. Charitable State-Controlled Foundation Human Tissue and Cell Research: Ethic and Legal Aspects in the Supply of Surgically Removed Human Tissue For Research in the Academic and Commercial Sector in Germany. Cell Tissue Bank. 2003;4(1):4956.

191. Riedmaier S, Klein K, Hofmann U, Keskitalo JE, Neuvonen PJ, Schwab M, et al. UDP-Glucuronosyltransferase (UGT) Polymorphisms Affect Atorvastatin Lactonization In Vitro and In Vivo. Clin Pharmacol Ther. 2010 Jan 30;87(1):65-73.

192. Hoffart E, Ghebreghiorghis L, Nussler a. K, Thasler WE, Weiss TS, Schwab M, et al. Effects of atorvastatin metabolites on induction of drug-metabolizing enzymes and membrane transporters through human pregnane $\mathrm{X}$ receptor. Br J Pharmacol. 2012;165(5):1595-608.

193. Zhang J, Chung TDY, Oldenburg KR. Journal of Biomolecular Screening. 1999;

194. Svärd J, Spiers JP, Mulcahy F, Hennessy M. Nuclear receptor-mediated induction 
of CYP450 by antiretrovirals: functional consequences of NR112 (PXR) polymorphisms and differential prevalence in whites and sub-Saharan Africans. $J$ Acquir Immune Defic Syndr. 2010 Dec 15;55(5):536-49.

195. Pissios P, Tzameli I, Kushner P, Moore DD. Dynamic stabilization of nuclear receptor ligand binding domains by hormone or corepressor binding. Mol Cell. 2000;6:245-53.

196. Lemaire G, Benod C, Nahoum V, Pillon A, Boussioux A-M, Guichou J-F, et al. Discovery of a Highly Active Ligand of Human Pregnane $X$ Receptor: A Case Study from Pharmacophore Modeling and Virtual Screening to \&quot;In Vivo\&quot; Biological Activity. Mol Pharmacol. 2007 Jun 12;72(3):572-81.

197. Kandel BA, Thomas M, Winter S, Damm G, Seehofer D, Burk O, et al. Genomewide comparison of the inducible transcriptomes of nuclear receptors CAR, PXR and PPARa in primary human hepatocytes. Biochim Biophys Acta. 2016 Sep;1859(9):1218-27.

198. Piedade R, Traub S, Bitter A, Nüssler AK, Gil JP, Schwab $M$, et al. Carboxymefloquine, the major metabolite of the antimalarial drug mefloquine, induces drug-metabolizing enzyme and transporter expression by activation of pregnane X receptor. Antimicrob Agents Chemother. 2015 Jan;59(1):96-104.

199. Bitter A, Rümmele P, Klein K, Kandel BA, Rieger JK, Nüssler AK, et al. Pregnane $X$ receptor activation and silencing promote steatosis of human hepatic cells by distinct lipogenic mechanisms. Arch Toxicol. 2015 Nov;89(11):2089-103.

200. Shizu R, Osabe M, Perera L, Moore R, Sueyoshi T, Negishi M. Phosphorylated nuclear receptor CAR forms a homodimer to repress its constitutive activity for ligand activation. Mol Cell Biol. 2017 Mar 6;MCB.00649-16.

201. Chen X, Baker SM, Chen G. Methotrexate induction of human sulfotransferases in Hep G2 and Caco-2 cells. J Appl Toxicol. 2005;25(5):354-60.

202. Chen X, Zhang J, Baker SM, Chen G. Human constitutive androstane receptor mediated methotrexate induction of human dehydroepiandrosterone sulfotransferase (hSULT2A1). Toxicology. 2007 Mar 7;231(2-3):224-33.

203. Wang $H$, Huang $H$, Li H, Teotico DG, Sinz M, Baker SD, et al. Activated pregnenolone $\mathrm{X}$-receptor is a target for ketoconazole and its analogs. Clin Cancer Res. 2007 Apr 15;13(8):2488-95.

204. Svecova L, Vrzal R, Burysek L, Anzenbacherova E, Cerveny L, Grim J, et al. Azole antimycotics differentially affect rifampicin-induced pregnane $X$ receptor-mediated CYP3A4 gene expression. Drug Metab Dispos. 2008 Feb;36(2):339-48.

205. Shukla SJ, Nguyen D-T, Macarthur R, Simeonov A, Frazee WJ, Hallis TM, et al. Identification of pregnane $X$ receptor ligands using time-resolved fluorescence resonance energy transfer and quantitative high-throughput screening. Assay Drug Dev Technol. 2009 Apr;7(2):143-69.

206. Chrencik JE, Orans J, Moore LB, Xue Y, Peng L, Collins JL, et al. Structural 
disorder in the complex of human pregnane $\mathrm{X}$ receptor and the macrolide antibiotic rifampicin. Mol Endocrinol. 2005 May;19(5):1125-34.

207. Moore TW, Mayne CG, Katzenellenbogen JA. Minireview: Not picking pockets: nuclear receptor alternate-site modulators (NRAMs). Mol Endocrinol. 2010;24(4):683-95.

208. Zollinger M, Waldmeier F, Hartmann S, Zenke G, Zimmerlin AG, Glaenzel U, et al. PIMECROLIMUS: ABSORPTION, DISTRIBUTION, METABOLISM, AND EXCRETION IN HEALTHY VOLUNTEERS AFTER A SINGLE ORAL DOSE AND SUPPLEMENTARY INVESTIGATIONS IN VITRO. Drug Metab Dispos. 2006 Jan 13;34(5):765-74.

209. Hirani VN, Raucy JL, Lasker JM. Conversion of the HIV protease inhibitor nelfinavir to a bioactive metabolite by human liver CYP2C19. Drug Metab Dispos. 2004 Dec 24;32(12):1462-7.

210. Niemi M, Backman JT, Fromm MF, Neuvonen PJ, Kivist?? KT. Pharmacokinetic Interactions with Rifampicin. Clin Pharmacokinet. 2003;42(9):819-50.

211. Deng $Y$, Sychterz C, Suttle AB, Dar MM, Bershas D, Negash $K$, et al. Bioavailability, metabolism and disposition of oral pazopanib in patients with advanced cancer. Xenobiotica. 2013 May 16;43(5):443-53.

212. Lynch C, Zhao J, Wang H, Xia M. Quantitative High-Throughput Luciferase Screening in Identifying CAR Modulators. Methods Mol Biol. 2016;1473:33-42.

213. Lynch C, Pan Y, Li L, Ferguson SS, Xia M, Swaan PW, et al. Identification of novel activators of constitutive androstane receptor from FDA-approved drugs by integrated computational and biological approaches. Pharm Res. 2013 Feb;30(2):489-501.

214. Yang H, Garzel B, Heyward S, Moeller T, Shapiro P, Wang H. Metformin represses drug-induced expression of CYP2B6 by modulating the constitutive androstane receptor signaling. Mol Pharmacol. 2014 Feb;85(2):249-60.

215. Duret C. Ketoconazole and miconazole are antagonists of the human glucocorticoid receptor: Consequences on the expression and function of the constitutive androstane receptor and the pregnane $\mathrm{X}$ receptor. Mol Pharmacol. 2006 Apr 11;70(1):329-39.

216. Mutoh S, Sobhany M, Moore R, Perera L, Pedersen L, Sueyoshi T, et al. Phenobarbital indirectly activates the constitutive active androstane receptor (CAR) by inhibition of epidermal growth factor receptor signaling. Sci Signal. 2013 May 7;6(274):ra31.

217. Wakeling AE, Guy SP, Woodburn JR, Ashton SE, Curry BJ, Barker AJ, et al. ZD1839 (Iressa): an orally active inhibitor of epidermal growth factor signaling with potential for cancer therapy. Cancer Res. 2002 Oct 15;62(20):5749-54.

218. Cheng H, An S-J, Dong S, Zhang Y-F, Zhang X-C, Chen Z-H, et al. Molecular mechanism of the schedule-dependent synergistic interaction in EGFR-mutant 
non-small cell lung cancer cell lines treated with paclitaxel and gefitinib. J Hematol Oncol. 2011 Jan 21;4:5.

219. Nallani SC, Goodwin B, Maglich JM, Buckley DJ, Buckley AR, Desai PB. Induction of cytochrome P450 3A by paclitaxel in mice: pivotal role of the nuclear xenobiotic receptor, pregnane X receptor. Drug Metab Dispos. 2003 May;31(5):681-4.

220. De Mattia E, Cecchin E, Roncato R, Toffoli G. Pregnane X receptor, constitutive androstane receptor and hepatocyte nuclear factors as emerging players in cancer precision medicine. Pharmacogenomics. 2016 Sep;17(14):1547-71.

221. Yamamoto Y. The Orphan Nuclear Receptor Constitutive Active/Androstane Receptor Is Essential for Liver Tumor Promotion by Phenobarbital in Mice. Cancer Res. 2004 Oct 15;64(20):7197-200. 